\title{
The 2008 HMDA Data: The Mortgage Market during a Turbulent Year
}

Robert B. Avery, Neil Bhutta, Kenneth P. Brevoort, Glenn B. Canner, and Christa N. Gibbs, of the Division of Research and Statistics, prepared this article. Cheryl R. Cooper and Christine Coyer provided research assistance.

The Home Mortgage Disclosure Act of 1975 (HMDA) requires most mortgage lending institutions with offices in metropolitan areas to publicly disclose information about their home-lending activity. The information includes the disposition of applications for mortgage credit, the characteristics of the home mortgages that lenders originate or purchase during a calendar year, the location of the properties related to those loans, and personal demographic and other information about the borrowers. ${ }^{1}$ The disclosures are intended not only to help the public determine whether institutions are adequately serving their communities' housing finance needs, but also to facilitate enforcement of the nation's fair lending laws and to inform investment in both the public and private sectors.

The Federal Reserve Board implements the provisions of HMDA through regulation. ${ }^{2}$ The Federal Financial Institutions Examination Council (FFIEC) is responsible for collecting the HMDA data and facilitating public access to the information. ${ }^{3}$ Each September, the FFIEC releases summary tables pertaining to lending activity from the previous calendar year for each reporting lender and aggregations of home-lending activity for each metropolitan statisti-

1. A description of the items reported under HMDA is provided in appendix A.

2. HMDA is implemented by Regulation C (12 C.F.R. pt. 203) of the Federal Reserve Board. Information about the regulation is available at www.federalreserve.gov.

3. The FFIEC (www.ffiec.gov) was established by federal law in 1979 as an interagency body to prescribe uniform examination procedures and to promote uniform supervision among the federal agencies responsible for the examination and supervision of financial institutions. The member agencies are the Board of Governors of the Federal Reserve System, the Federal Deposit Insurance Corporation, the National Credit Union Administration, the Office of the Comptroller of the Currency, the Office of Thrift Supervision, and representatives from state bank supervisory agencies. cal area (MSA) and for the nation as a whole. ${ }^{4}$ The FFIEC also makes available a consolidated data file containing virtually all the reported information for each lending institution. ${ }^{5}$

The 2008 HMDA data consist of information reported by about 8,400 home lenders, including all of the nation's largest mortgage originators. The loans reported are estimated to represent the majority of home lending nationwide. Thus, they likely provide a broadly representative picture of home lending in the United States.

This article presents a number of findings from our initial review of the 2008 HMDA data. Three of those findings are noted here. First, the 2008 HMDA data reflect the ongoing difficulties in the housing and mortgage markets. Reported loan application and origination volumes fell sharply from 2007 to 2008 after already falling considerably from 2006 to 2007. A reduction in lending occurred among all groups of borrowers regardless of race, ethnicity, or income, although lending for some groups declined more sharply than for others.

Second, the Federal Housing Administration's (FHA) role in the mortgage market expanded considerably during 2008. The increasing use of FHAinsured loans in 2008 appears to be related to a number of factors, including difficulties faced by private mortgage insurance (PMI) companies and their pullback from the marketplace.

Third, the data show a decline in the incidence of reported higher-priced lending between 2007 and 2008.6 However, atypical changes in the interest rate environment, related primarily to widening spreads

4. For the 2008 data, the FFIEC prepared and made available to the public more than 51,100 MSA-specific HMDA reports on behalf of reporting institutions. The FFIEC also makes available to the public reports about private mortgage insurance (PMI) activity. All the HMDA and PMI reports are available on the FFIEC's reports website at www.ffiec.gov/reports.htm.

5. The only reported items not included in the data made available to the public are the loan application number, the date of application, and the date on which action was taken on the application. Those items are withheld to help ensure that the individuals involved in the application cannot be identified.

6. Loans are reported as higher priced in HMDA if their annual percentage interest rate (APR) spread is 3 percentage points or higher 
between the yields on Treasury securities and the interest rates on prime mortgage loans, resulted in a large number of loans being reported as higher priced in 2008 that would not have been so reported a year earlier. As a result, the decline in the incidence of reported higher-priced lending actually understates the true extent of the decline in subprime lending. Also the distortion led to an increase in the reporting of higher-priced loans for FHA even though it appears that FHA pricing was relatively unchanged.

The article proceeds in seven major sections. The next section briefly describes the economic environment in 2008. The following two sections provide an overview of the mortgage market along several dimensions in 2008 and its evolution over time based on the HMDA data. The fourth section discusses in detail how changes in the interest rate environment affected the reporting of higher-priced lending in the HMDA data and provides estimates of higher-priced lending that adjusts for these changes. The fifth section analyzes the surge in government-backed lending, assessing the importance of higher loan limits and changes in pricing and coverage by PMI companies. This section also draws on industry data to help describe changes in the credit-risk profile of government-backed loans. The sixth section describes how the reduction in mortgage lending during 2008 played out across different demographic groups. And finally, the last section presents analyses that speak to issues of fair lending.

\section{8: A TURBULENT YEAR}

The 2008 HMDA data reflect a sharp deterioration in economic conditions during the year. The housing market's continued decline was reflected in the Federal Housing Finance Agency's (FHFA) nationwide home price index, which posted a year-over-year decline of more than 8 percent by November 2008, compared with less than 3 percent in January. At the same time, mortgage-related losses continued to weigh on the confidence of investors and the health of financial institutions. A number of major financial institutions either failed, merged under distress, or received government assistance. The governmentsponsored enterprises (GSEs) Fannie Mae and Freddie Mac were placed into conservatorship by the FHFA in September. ${ }^{7}$

for a first lien or 5 percentage points or higher for a junior lien than the yield on a comparable-maturity Treasury security.

7. To maintain the GSEs' ability to purchase home mortgages, the Treasury announced plans to establish a backstop lending facility for the GSEs, to purchase up to $\$ 100$ billion of preferred stock in each of the two firms, and to initiate a program to purchase agency mortgage-
Difficulties in the housing and financial markets advanced into a broad-based economic recession. ${ }^{8}$ By December 2008, the unemployment rate had risen to 7.2 percent from 4.9 percent a year earlier, and the number of employed individuals fell by nearly 3 million during the year. ${ }^{9}$ The deterioration in household income and wealth as well as fears about buying into a falling market may have weakened demand for housing and mortgages.

On the supply side, strained lending institutions, facing the risks posed by falling home prices and a weakening economy, were apprehensive or unable to offer loans that did not have some form of government backing. Potential borrowers, especially those with blemished credit histories and those seeking "jumbo" mortgages, likely found it more difficult than in previous years to obtain a mortgage. ${ }^{10}$ Those with adequate credit histories but little money for a down payment also faced a more challenging situation since PMI companies, which suffered large losses in 2007 and 2008, tightened their standards and raised prices. ${ }^{11}$ Lenders also sharply curtailed the issuance of second-lien loans used heavily in previous years to help finance home purchases. Partly in response to difficulties in the private market, the government raised the size limits on loans eligible to be purchased by Fannie Mae or Freddie Mac and insured by the FHA as well as the guarantee limit for loans backed by the Department of Veterans Affairs (VA) as part of the Economic Stimulus Act of 2008.

\section{MoRTGAGE MARKET TRENDS FROM THE HMDA DATA}

For 2008, 8,388 institutions reported under HMDA: 3,942 commercial banks, 913 savings institutions

backed securities. See Board of Governors of the Federal Reserve System (2009), Monetary Policy Report to the Congress (Washington: Board of Governors, February), www.federalreserve.gov/ monetarypolicy/mpr_20090224_part1.htm.

8. The National Bureau of Economic Research declared the start of the recession as December 2007.

9. Employment statistics from the Bureau of Labor Statistics; based on individuals 16 years or older.

10. Industry sources indicate that the dollar amount of originations of subprime loans fell 88 percent from 2007 to 2008, to a level of $\$ 23$ billion. Jumbo loans are loans that exceed the size limits set for loans that Fannie Mae and Freddie Mac are permitted to purchase (commonly referred to as conforming loans). Available data indicate that the dollar amount of originations of jumbo loans fell 72 percent from 2007 to 2008, to a level of $\$ 97$ billion. See Inside Mortgage Finance (2009), The 2009 Mortgage Market Statistical Annual, Vol. 1: The Primary Market (Bethesda, Md.: Inside Mortgage Finance Publications).

11. See Mortgage Insurance Companies of America (2009), 2009_ 2010 Fact Book \& Member Directory (Washington: MICA), www. privatemi.com/news/factsheets/2009-2010.pdf. 
1. Distribution of reporters covered by the Home Mortgage Disclosure Act, by type of institution, 2006-08

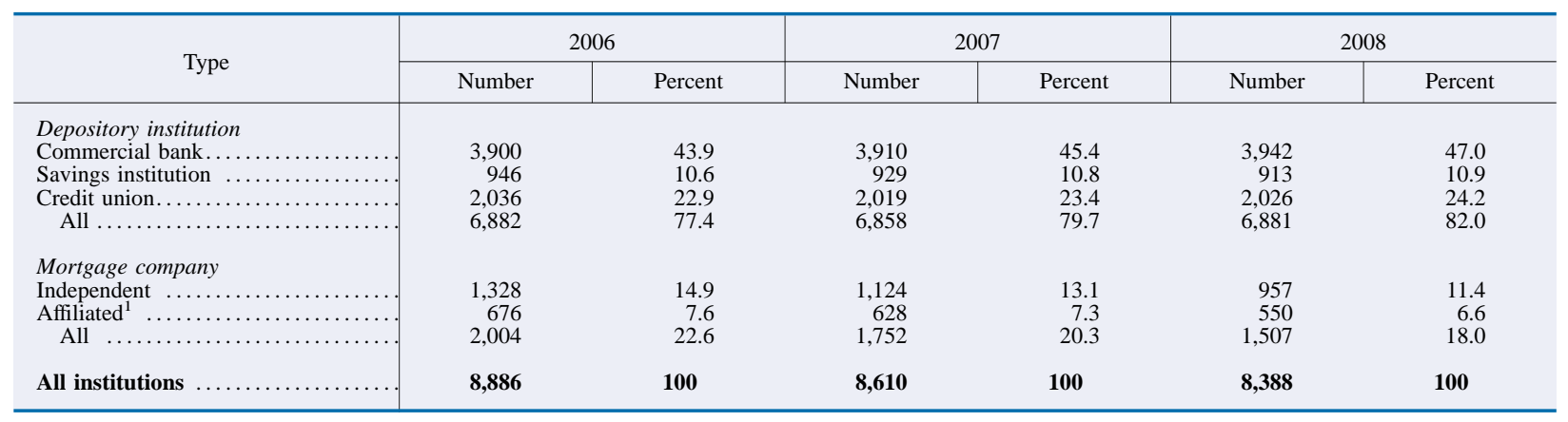

Note: Here and in all subsequent tables, components may not sum to totals because of rounding.

1. Subsidiary of a depository institution or an affiliate of a bank holding company.

(savings and loans and savings banks), 2,026 credit unions, and 1,507 mortgage companies (table 1). ${ }^{12}$ The number of reporting institutions fell nearly 3 percent from 2007, primarily because of a relatively large decline in the number of independent mortgage companies - that is, mortgage companies that were neither subsidiaries of depository institutions nor affiliates of bank or savings institution holding companies that reported data.

Reporting lenders submitted information on 14.2 million applications for home loans of all types in 2008, down 34 percent from 2007 and almost 50 percent from 2006 (table 2). Lenders also reported information on 2.9 million loans that they had purchased from other institutions and on 276,000 requests for preapprovals of home-purchase loans that did not result in an application for a loan (preapproval data not shown in table).

The top panel of figure 1, which shows the monthly counts of loans, indicates a downward trend in homepurchase lending from 2006 to 2008 . For instance, the 2006 peak month for home-purchase lending (in June) was more than 400,000 loans, compared with

12. Not all mortgage lenders have to provide HMDA data. Depositories must have had an office in a metropolitan area and had assets of more than $\$ 37,000,000$ at the end of 2007 to report data for 2008. For filing year 2008, 55.7 percent of the commercial banks in existence on December 31, 2008, filed HMDA data. However, the filers had 93.0 percent of the total mortgage dollars outstanding on commercial bank portfolios at that time. For savings institutions, 70.9 percent of existing institutions holding 94.1 percent of the mortgage dollars filed. For credit unions, only 25.4 percent of the institutions filed; however, these institutions held 92.5 percent of the mortgage dollars outstanding on credit union balance sheets.

Independent mortgage banks needed to meet other criteria related to their dollar volume of mortgage lending, the share of mortgage lending of their total lending, and their lending in metropolitan areas to be eligible for reporting. There is no comprehensive list of independent mortgage lenders, so it is difficult to know the full scope of HMDA data coverage of such lenders.
SOURCE: Here and in the subsequent tables and figures except as noted, Federal Financial Institutions Examination Council, data reported under the Home Mortgage Disclosure Act (www.ffiec.gov/hmda).

less than 300,000 loans at the peak month (June) in 2008. The bottom panel of figure 1 indicates that refinance lending jumped at the beginning of 2008 to a level in February exceeding any month in 2006 or

1. Volume of home-purchase and refinance originations and annual percentage rate, by month, 2006-08

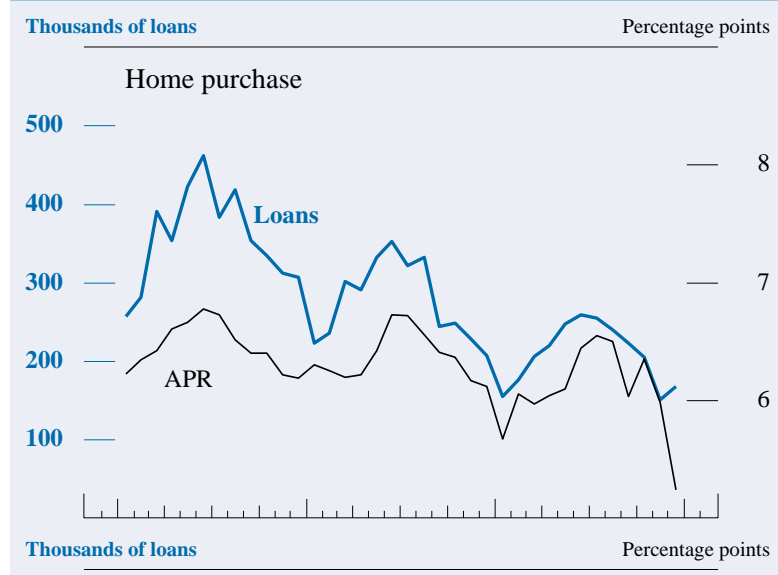

Refinance

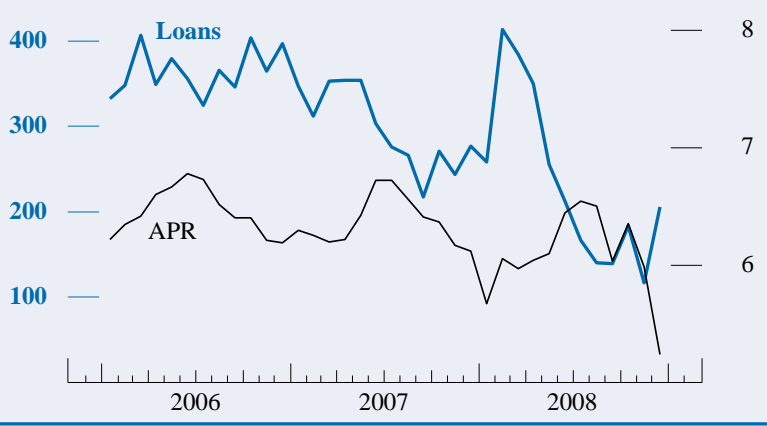

Note: The data are monthly. Loans are first-lien mortgages for site-built properties and exclude business loans. Annual percentage rate (APR) is the average monthly rate for a 30-year fixed-rate mortgage from the Primary Mortgage Market Survey, as reported by the Federal Financial Institutions Examination Council, www.ffiec.gov/ratespread/newcalc.aspx. 
2. Home loan and reporting activity of lending institutions covered under the Home Mortgage Disclosure Act, 1990-2008 Number

\begin{tabular}{|c|c|c|c|c|c|c|c|c|}
\hline \multirow{3}{*}{ Year } & \multicolumn{4}{|c|}{ Applications (millions) } & \multirow{3}{*}{$\begin{array}{c}\text { Loans } \\
\text { purchased } \\
\text { (millions) }\end{array}$} & \multirow{3}{*}{$\begin{array}{c}\text { Total }^{1} \\
\text { (millions) }\end{array}$} & \multirow{3}{*}{ Reporters } & \multirow{3}{*}{$\begin{array}{l}\text { Disclosure } \\
\text { reports }^{2}\end{array}$} \\
\hline & \multicolumn{3}{|c|}{$\begin{array}{l}\text { Applications received for home loans on } 1-4 \\
\text { family properties, and home loans purchased } \\
\text { from another institution }\end{array}$} & \multirow[t]{2}{*}{ Total $^{1}$} & & & & \\
\hline & Home purchase & Refinance & $\begin{array}{c}\text { Home } \\
\text { improvement }\end{array}$ & & & & & \\
\hline 1990. & 3.3 & 1.1 & 1.2 & 5.5 & 1.2 & 6.7 & 9,332 & 24,041 \\
\hline 1991 . & 3.3 & 2.1 & 1.2 & 6.6 & 1.4 & 7.9 & 9,358 & 25,934 \\
\hline 1992. & 3.5 & 5.2 & 1.2 & 10.0 & 2.0 & 12.0 & 9,073 & 28,782 \\
\hline 1993. & 4.5 & 7.7 & 1.4 & 13.6 & 1.8 & 15.4 & 9.650 & 35,976 \\
\hline 1994 . & 5.2 & 3.8 & $\begin{array}{l}1.4 \\
1.7\end{array}$ & 10.7 & 1.5 & 12.2 & 9,858 & 38,750 \\
\hline 1995. & 5.5 & 2.7 & 1.8 & 10.0 & 1.3 & 11.2 & 9,539 & 36,611 \\
\hline 1996. & 6.3 & 4.5 & $\begin{array}{l}1.0 \\
2.1\end{array}$ & $\begin{array}{l}10.0 \\
13.0\end{array}$ & $\begin{array}{l}1.3 \\
1.8\end{array}$ & 14.8 & 9,328 & 42,946 \\
\hline 1997. & 6.8 & 5.4 & 2.2 & 14.3 & 2.1 & 16.4 & 7,925 & 47,416 \\
\hline 1998 . & 8.0 & 11.4 & 2.0 & 21.4 & 3.2 & 24.7 & 7,836 & 57,294 \\
\hline 1999 . & 8.4 & 9.4 & 2.1 & 19.9 & 3.0 & 22.9 & 7,832 & 56,966 \\
\hline 2000. & 8.3 & 6.5 & 2.0 & 16.8 & 2.4 & 19.2 & 7,713 & 52,776 \\
\hline 2001. & 7.7 & 14.3 & 1.9 & 23.8 & 3.8 & 27.6 & 7,631 & 53,066 \\
\hline 2002 . & 7.4 & 17.5 & 1.5 & 26.4 & 4.8 & 31.2 & 7,771 & 56,506 \\
\hline 2003. & 8.2 & 24.6 & 1.5 & 34.3 & 7.2 & 41.5 & 8,121 & 65,808 \\
\hline $2004 \ldots \ldots$ & 9.8 & 16.1 & 2.2 & 28.1 & 5.1 & 33.3 & 8,853 & 72,246 \\
\hline 2005 . & 11.7 & 15.9 & 2.5 & 30.2 & 5.9 & 36.0 & 8,848 & 78,193 \\
\hline 2006 & 10.9 & 14.0 & 2.5 & 27.5 & 6.2 & 33.7 & 8,886 & 78,638 \\
\hline $2007 \ldots$ & 7.6 & 11.5 & 2.2 & 21.4 & 4.8 & 26.2 & 8,610 & 63,055 \\
\hline $2008 \ldots \ldots$ & 5.0 & 7.7 & 1.4 & 14.2 & 2.9 & 17.1 & 8,388 & 51,109 \\
\hline
\end{tabular}

NotE: Except as noted, applications exclude requests for preapproval that were denied by the lender or were accepted by the lender but not acted upon by the borrower. In this article, applications are defined as being for a loan on a specific property; they are thus distinct from requests for preapproval, which are not related to a specific property.

2007. Refinance lending then fell sharply during the remainder of 2008. Figure 1 also shows that the annual percentage interest rate (APR) for a 30-year fixed-rate prime mortgage fell sharply at the end of 2007 to levels not seen in several years; it continued to fall in early 2008 and dipped below 6 percent in January 2008, which may have triggered the jump in refinance lending. ${ }^{13}$

\section{The Potential Effect of Nonreporters on Lending Volume in the 2008 HMDA Data}

As part of the HMDA data collection effort, the Federal Reserve Board tracks each financial institution that is expected to report (including all lenders that reported data for the previous calendar year) and then contacts those that did not submit a report. ${ }^{14}$ In some cases, nonreporting is due to a cessation of

13. The APRs for prime loans are based on data from Freddie Mac's Primary Mortgage Market Survey and reflect interest rates and discount points offered to consumers during the first three days of each week. For more details, see note 29. Loan counts in figure 1 are aggregated to the monthly level using the date of loan origination, as opposed to an earlier date when the interest rate for the loan was locked. If the HMDA data were aggregated using the "lock" date, the spike in refinancings would likely occur closer to the January dip in the APR.

14. Sometimes contacting a nonreporting lender is impossible because the firm has ceased operations.
1. Applications for multifamily homes are included only in the total columns; for 2008, these applications numbered 42,792.

2. A report covers the mortgage lending activity of a lender in a single metropolitan statistical area in which it had an office during the year.

business; in others, it is the result of a merger, acquisition, or consolidation. When a merger, acquisition, or consolidation occurs, all lending by the institutions covered by HMDA in that year is reported by the surviving entity; only when an institution goes out of business is the volume of reported loans possibly affected.

The Federal Reserve's respondent tracking report records what happened to each institution that failed to report. For institutions that ceased operations, the tracking report also records, to the extent possible, the month that operations were discontinued. The tracking report indicates that 15 institutions that reported HMDA data for 2007 ceased operations during 2008 or at the beginning of 2009 and did not report lending activity for $2008 . .^{15}$ Of the 15 nonreporting institutions, 3 were banking institutions and 12 were independent mortgage companies.

Although it is not possible to know how many loans these 15 institutions originated in 2008 before discontinuing operations, one can gauge their poten-

15. The list of lenders that ceased operations and did not report is as comprehensive as possible at this time. If additional information becomes available, the list will be updated on the Federal Reserve Board's website. For a list of the institutions that ceased operations and did not report, see appendix table A.1, which has been posted separately as an Excel file. 
tial importance by measuring their lending activity in $2007 .{ }^{16}$ In the aggregate, these 15 nonreporting companies accounted for about 5 percent of all conventional first-lien loans for site-built properties in the 2007 HMDA data (data not shown in tables). ${ }^{17}$ The tracking reports indicate that the 15 nonreporting institutions had exited the marketplace by the middle of 2008, so their effects on the completeness of the HMDA data are confined to the first half of the year.

\section{Government-Backed Lending}

Government-backed loans- those insured by the FHA and those backed by guarantees from the VA, the Farm Service Agency, or the Rural Housing Servicerose in 2008 relative to 2007. The rise in FHAinsured lending was particularly large. The number of reported FHA-insured loans was almost three times greater in 2008 than in 2007, and the FHA-insured share of home-purchase and refinance loans rose to more than 21 percent in 2008 from less than 6 percent in 2007 (table 3). ${ }^{18}$ Moreover, by December of 2008, the FHA's share of home-purchase and refinance lending was about 30 percent (data not shown in tables).

Lenders typically require borrowers to purchase mortgage insurance (through the FHA or PMI companies) or a credit guarantee (through the VA, for example) when the borrower provides a small down

16. An estimate of the underreporting of first liens for singlefamily properties can be made using quarterly financial data filed with the Office of Thrift Supervision for the two largest institutions, Washington Mutual Bank and IndyMac Bank. These institutions accounted for 88 percent of the loans made in 2007 by the 15 nonreporting institutions. Assuming the first liens on one- to fourfamily properties originated by these thrifts in 2008 were of the same average loan amount as those originated in the corresponding quarters in the 2007 HMDA data, the 2008 HDMA data is underreported because of these two institutions by about 1.7 percent for the year: 59,000 loans in the first quarter (3.2 percent), 39,500 in the second (2.2 percent), 2,900 in the third ( 0.2 percent), and 4,000 in the fourth ( 0.3 percent). These values may not be evenly distributed across loan purposes. In 2007, Washington Mutual originated refinance loans as a higher proportion of all of its lending in all quarters than did all HMDA lenders (a 15 percentage point average difference). IndyMac's relative shares were similar to those of HMDA lenders overall. Most of the loans originated by Washington Mutual in 2008 were included in the HMDA data as purchased loans by JPMorgan Chase Bank and not as originations.

17. Market shares reported in this article are based on the number of loans and not the dollar amounts.

18. Loans are for owner-occupied, one- to four-family properties. Junior-lien loans and loans for manufactured homes are included because the HMDA data prior to 2004 do not separately identify these loans. The FHA share of home-purchase and refinance lending in 2008, excluding junior-lien and manufactured-home loans, was 22.5 percent. For more information about the reporting details, see Robert B. Avery, Glenn B. Canner, and Robert E. Cook (2005), "New Information Reported under HMDA and Its Application in Fair Lending Enforcement," Federal Reserve Bulletin, vol. 91 (Summer), pp. 344-94.
3. Share of home loans, by type of loan, 1990-2008 Percent

\begin{tabular}{|c|c|c|c|c|}
\hline & Conventional & $\begin{array}{c}\text { FHA } \\
\text { insured }\end{array}$ & $\begin{array}{c}\text { VA/other } \\
\text { guaranteed }^{1}\end{array}$ & All \\
\hline 1990 & 77.4 & 18.1 & 4.5 & 100 \\
\hline 1991 & 81.7 & 13.8 & 4.5 & 100 \\
\hline 1992 & 87.1 & 8.8 & 4.1 & 100 \\
\hline 1993 & 81.5 & 13.0 & 5.5 & 100 \\
\hline 1994 & 81.5 & 12.6 & 5.9 & 100 \\
\hline 1995 & 81.9 & 12.7 & 5.5 & 100 \\
\hline 1996 & 82.5 & 12.7 & 4.8 & 100 \\
\hline 1997 & 82.7 & 12.9 & 4.4 & 100 \\
\hline 1998 & 85.7 & 10.0 & 4.3 & 100 \\
\hline 1999 & 84.8 & 11.8 & 3.4 & 100 \\
\hline 2000 & 84.4 & 12.7 & 2.8 & 100 \\
\hline 2001 & 87.1 & 10.3 & 2.6 & 100 \\
\hline 2002 & 90.1 & 7.6 & 2.3 & 100 \\
\hline 2003 & 91.3 & 6.2 & 2.5 & 100 \\
\hline 2004 & 93.0 & 5.1 & 1.9 & 100 \\
\hline 2005 & 95.3 & 3.4 & 1.3 & 100 \\
\hline 2006 & 95.2 & 3.5 & 1.3 & 100 \\
\hline 2007 & 92.5 & 5.6 & 1.9 & 100 \\
\hline 2008 & 74.3 & 21.5 & 4.2 & 100 \\
\hline
\end{tabular}

NotE: Includes home-purchase and refinance loans for 1-4 family, owneroccupied properties.

1. Includes loans guaranteed by the U.S. Department of Veterans Affairs, the Farm Service Agency, or the Rural Housing Service.

FHA Federal Housing Administration.

payment. ${ }^{19}$ Such credit enhancements protect lenders against loss if the borrower defaults.

The VA guarantees a percentage of the loan amount up to a certain limit (but with no cap on the loan size), while the FHA cannot insure mortgages that are larger than legislated limits. Historically, these limits have been set at levels that were sufficiently low that many homebuyers in areas with high home prices have not been able to use these programs. Under the Economic Stimulus Act of 2008, the limits were raised in high-cost areas. In a later section, "The Surge in FHA and VA Lending," we will analyze more closely the contribution of increased limits to the increase in FHA and VA-backed lending. We will also examine whether difficulties facing PMI companies contributed to the shift to government-backed lending.

\section{Loan Sales}

The HMDA data document the importance of the secondary market for home loans. Just over 73 percent of the first-lien home loans reported in 2008 were sold during the same year (table 4). ${ }^{20}$ Notably, the rise in government-backed lending between 2007 and 2008 described earlier has resulted in a sharp increase in the proportion of loans sold into pools

19. For more details about PMI, see appendix B, "Private Mortgage Insurance Data."

20. Loans that are sold in a different calendar year than the year of origination are recorded as being held in the lender's portfolio in the HMDA data. 
4. Distribution of loans sold during year of origination, by type of purchaser, number of loans, and amount of loans, 2006-08 Percent

\begin{tabular}{|c|c|c|c|c|c|c|}
\hline \multirow[b]{2}{*}{ Type of purchaser } & \multicolumn{2}{|c|}{2006} & \multicolumn{2}{|c|}{2007} & \multicolumn{2}{|c|}{2008} \\
\hline & $\begin{array}{l}\text { By number } \\
\text { of loans }\end{array}$ & $\begin{array}{c}\text { By amount } \\
\text { of loans }\end{array}$ & $\begin{array}{l}\text { By number } \\
\text { of loans }\end{array}$ & $\begin{array}{c}\text { By amount } \\
\text { of loans }\end{array}$ & $\begin{array}{l}\text { By number } \\
\text { of loans }\end{array}$ & $\begin{array}{c}\text { By amoun } \\
\text { of loans }\end{array}$ \\
\hline Fannie Mae & 17.2 & 14.3 & 23.4 & 21.2 & 25.8 & 27.1 \\
\hline Ginnie Mae. & 2.2 & 1.4 & 3.5 & 2.4 & 11.4 & 9.5 \\
\hline Freddie Mac & 10.7 & 8.9 & 15.3 & 13.4 & 16.2 & 16.2 \\
\hline Farmer Mac .......... & .0 & .0 & .0 & .0 & .0 & .0 \\
\hline Private securitization ........... & 9.0 & 11.0 & 3.6 & 5.0 & .5 & .6 \\
\hline Commercial bank or savings & & & & & & \\
\hline institution ............... & 6.9 & 7.6 & 6.8 & 7.6 & 8.8 & 8.8 \\
\hline Insurance company & 15.7 & 15.5 & 10.5 & 10.3 & 9.7 & 9.4 \\
\hline Affiliate of institution & 14.5 & 16.2 & 21.4 & 23.4 & 12.3 & 13.5 \\
\hline Other $\ldots \ldots \ldots \ldots \ldots$. & 23.8 & 25.0 & 15.6 & 16.7 & 15.4 & 14.8 \\
\hline Total ................. & 100 & 100 & 100 & 100 & 100 & 100 \\
\hline Мемо & & & & & & \\
\hline Share of all originations sold & 72.2 & 71.9 & 69.5 & 67.0 & 73.2 & 72.0 \\
\hline
\end{tabular}

NoTE: Includes only first-lien loans.

guaranteed by the Government National Mortgage Association (Ginnie Mae).

More prominent in the secondary market are Fannie Mae and Freddie Mac. For the most part, the purchases made by Fannie Mae and Freddie Mac consist of conventional loans originated to purchase homes or to refinance existing loans. Fannie Mae and Freddie Mac are restricted by law to purchase mortgages with origination balances below a specific amount, known as the conforming loan limit. As with the FHA loan limits mentioned earlier, the Economic Stimulus Act of 2008 increased the conforming loan limits. $^{21}$

In 2008, sales to Fannie Mae and Freddie Mac accounted for about 42 percent of the loans reported as sold, compared with about 28 percent in 2006. At least in part, this increase in market share reflects the reduction during this period in the higher-priced share of loans, which the GSEs typically do not purchase directly. Higher-priced loans were often sold through the private securitization process; indeed, loans sold through this process diminished considerably, from about 10 percent of sold loans in 2006 to less than 1 percent in 2008 .

\section{Credit Unions}

A credit union is a cooperative financial institution formed by a group of people with a common bond, such as employees of a firm or members of a religious organization, university, or governmental entity. ${ }^{22}$ Members of a credit union pool their funds to extend credit to their fellow members. In 2008, about 7,700

21. For more on the conforming loan limit, see www.fhfa.gov/ Default.aspx ?Page $=185$.

22. The notion of a common bond has been expanded some in recent years, for example, to include individuals from broad geographic areas. credit unions across the country served upward of 90 million members. The vast majority of credit unions are small measured by asset size, and many do little home lending. As such, only about 2,000 credit unions report under HMDA each year (table 1).

Unlike other types of lenders, credit unions have not experienced a significant reduction in homelending activity over the past couple of years (table 5.A). As a consequence, their share of one- to four-family, site-built HMDA loans has risen, particularly for junior liens (a 28.2 percent share in 2008). Their high market share of junior liens can be explained, in part, by the collapse of the piggyback market, discussed later in the section "Piggyback Lending." Piggyback junior-lien home-purchase loans are issued as part of a purchase package. Less than 5 percent of credit union junior liens have been for home purchases, so they were not particularly affected by this collapse.

The credit union data afford a unique opportunity to benchmark the HMDA data. Unlike other depositories, all credit unions are required to report their aggregate first- and junior-lien mortgage originations by number each year as part of their regulatory filings. Savings and loan institutions that report to the Office of Thrift Supervision also report aggregated information, but in dollar amounts instead of number of loans (table 5.B). These data allow a determination of the HMDA-filer coverage relative to all credit union and savings and loan mortgage lending. The credit union data show that for 2008 , almost 90 percent of all credit union mortgage originations were made by lenders who reported under HMDA. For first liens, the numbers reported in regulatory filings by these lenders corresponded relatively closely to the number reported in HMDA (93 percent of first-lien loan originations are reported in HMDA, data derived 
5. Home lending, 2004-08

A. By credit unions, number of loans

\begin{tabular}{|c|c|c|c|c|c|c|c|c|c|c|c|}
\hline \multirow[b]{3}{*}{ Year } & \multirow{2}{*}{\multicolumn{2}{|c|}{ First liens }} & \multirow{2}{*}{\multicolumn{2}{|c|}{ Junior liens }} & \multirow{2}{*}{\multicolumn{2}{|c|}{ Unsecured }} & \multicolumn{5}{|c|}{$\begin{array}{l}\text { МЕмо: } \\
\text { Originations in credit union reports of condition and income }\end{array}$} \\
\hline & & & & & & & \multicolumn{2}{|c|}{ First liens } & \multicolumn{2}{|c|}{ Closed-end junior liens } & \multirow{2}{*}{$\begin{array}{l}\text { Number o } \\
\text { HELOCs } \\
\text { originated } \\
\text { by HMDA } \\
\text { reporters }\end{array}$} \\
\hline & Number & $\begin{array}{c}\text { HMDA } \\
\text { percent } \\
\text { distribution }\end{array}$ & Number & $\begin{array}{c}\text { HMDA } \\
\text { percent } \\
\text { distribution }\end{array}$ & Number & $\begin{array}{c}\text { HMDA } \\
\text { percent } \\
\text { distribution }\end{array}$ & \begin{tabular}{|c|} 
Number \\
originated \\
by HMDA \\
reporters \\
\end{tabular} & \begin{tabular}{|c} 
HMDA \\
share of all \\
such liens
\end{tabular} & \begin{tabular}{|c|} 
Number \\
originated \\
by HMDA \\
reporters
\end{tabular} & $\begin{array}{c}\text { HMDA } \\
\text { share of all } \\
\text { such liens }\end{array}$ & \\
\hline 2004. & 357,433 & 2.7 & 166,028 & 9.9 & 21,940 & 13.7 & 381,683 & 87.2 & 343,150 & 88.1 & 740,962 \\
\hline 2005. & 341,307 & 2.7 & 197,070 & 7.6 & 20,382 & 12.9 & 372,517 & 88.1 & 412,253 & 89.9 & 651,507 \\
\hline 2006. & 291,863 & 2.7 & 237,361 & 7.8 & 19,053 & 11.7 & 329,108 & 87.7 & 497,898 & 90.8 & 539,658 \\
\hline 2007. & 313,447 & 3.7 & 205,231 & 12.0 & 19,128 & 12.0 & 336,229 & 88.7 & 424,611 & 90.8 & 461,292 \\
\hline $2008 \ldots$ & 359,645 & 5.5 & 145,500 & 28.2 & 18,656 & 11.4 & 386,079 & 89.8 & 305,204 & 89.6 & 451,725 \\
\hline
\end{tabular}

NotE: Excludes loans for multifamily properties. HELOC Home equity line of credit.
Source: Credit union reports of condition and income from National Credit Union Administration.

\section{Home lending, 2004-08}

B. By savings and loan institutions, thousands of dollars

\begin{tabular}{|c|c|c|c|c|c|c|c|c|c|c|}
\hline \multirow{3}{*}{ Year } & \multirow{2}{*}{\multicolumn{2}{|c|}{ First liens }} & \multirow{2}{*}{\multicolumn{2}{|c|}{ Junior liens }} & \multirow{2}{*}{\multicolumn{2}{|c|}{ Unsecured }} & \multicolumn{4}{|c|}{$\begin{array}{c}\text { MEм0: } \\
\text { Originations in thrift reports } \\
\text { of condition and income }\end{array}$} \\
\hline & & & & & & & \multicolumn{2}{|c|}{ First liens ${ }^{1}$} & \multicolumn{2}{|c|}{ Closed-end junior liens $^{1}$} \\
\hline & $\begin{array}{c}\text { Thousands of } \\
\text { dollars }\end{array}$ & $\begin{array}{c}\text { HMDA } \\
\text { percent } \\
\text { distribution }\end{array}$ & $\begin{array}{c}\text { Thousands of } \\
\text { dollars }\end{array}$ & $\begin{array}{c}\text { HMDA } \\
\text { percent } \\
\text { distribution }\end{array}$ & $\begin{array}{c}\text { Thousands of } \\
\text { dollars }\end{array}$ & $\begin{array}{c}\text { HMDA } \\
\text { percent } \\
\text { distribution }\end{array}$ & \begin{tabular}{|c|} 
Thousands of \\
dollars \\
originated \\
by HMDA \\
reporters \\
\end{tabular} & $\begin{array}{c}\text { HMDA share } \\
\text { of all such } \\
\text { liens }\end{array}$ & \begin{tabular}{|c|} 
Thousands of \\
dollars \\
originated \\
by HMDA \\
reporters
\end{tabular} & $\begin{array}{c}\text { HMDA share } \\
\text { of all such } \\
\text { liens }\end{array}$ \\
\hline 2004 & $581,777,825$ & 23.4 & $11,797,538$ & 15.4 & 48,902 & 3.6 & $596,252,410$ & 98.7 & & \\
\hline 2005 & $582,083,085$ & 21.1 & $22,907,264$ & 17.4 & 65,940 & 4.4 & $648,433,523$ & 98.7 & & \\
\hline 2006 & $457,429,907$ & 18.7 & $22,984,024$ & 13.5 & 135,685 & 8.2 & $436,043,072$ & 78.6 & & \\
\hline 2007 & $486,826,148$ & 24.7 & $16,573,910$ & 16.8 & 155,330 & 9.8 & $562,351,440$ & 98.9 & $63,642,622$ & 97.9 \\
\hline 2008 & $313,662,849$ & 22.7 & $3,973,576$ & 13.4 & 189,703 & 11.3 & $265,559,705$ & 86.1 & $30,351,849$ & 85.9 \\
\hline
\end{tabular}

Note: Excludes loans for multifamily properties and those originated by institutions that did not report origination data to the Office of Thrift Supervision for the full calendar year.

1. Prior to 2007, data from the Office of Thrift Supervision did not differentiate between first and junior liens. As a result, the column for first liens for
2004-06 includes junior liens.

Not available.

SourCE: Thrift reports of condition and income from the Office of Thrift Supervision. from table 5.A). However, for closed-end junior liens, only about 48 percent appear to be reported, which suggests that many of these loans are junior liens not reportable under HMDA rules because they are neither for home purchase, home improvement, or refinancing of an existing lien.

\section{Lending for Manufactured Homes}

Since 2004, the HMDA data have distinguished between loans secured by site-built properties and those related to manufactured homes. Manufacturedhome lending differs from lending for site-built properties along a number of dimensions, including typical loan amounts, borrower incomes, and the share of such loans that are higher priced.

The reported number of manufactured-home loans fell by about the same proportion as for site-built homes from 2007 through 2008 (table 6). However, when measured from 2005 (a year when mortgage markets were quite robust), the decline in loan activ- ity was much steeper for site-built homes than for manufactured homes. Over this longer period, the number of loans to buy site-built homes fell 48 percent, and the number to buy manufactured homes fell 25 percent.

The mean loan amount used to purchase manufactured homes in 2008 was $\$ 75,000$, which was much smaller than the mean loan amount of $\$ 217,000$ for site-built homes. Similarly, the mean income of borrowers purchasing manufactured homes in 2008 was $\$ 48,400$, which was much smaller than the mean income of $\$ 93,300$ for purchasers of site-built homes for the same period.

\section{Lending for Non-Owner-Occupied Properties}

One factor contributing to the strong performance of housing markets over the first half of this decade was the growth in sales of homes to investors or individuals purchasing second or vacation homes, which are collectively referred to here as non-owner-occupied 
6. Manufactured and site-built home lending, 2004-08

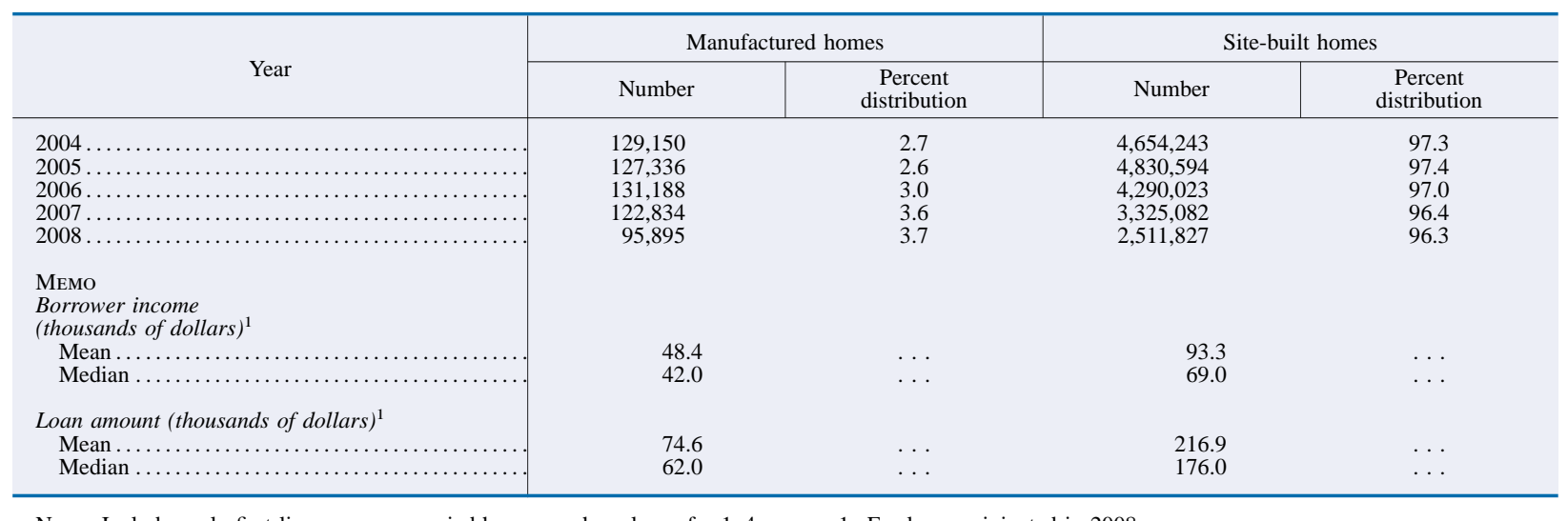

NoTE: Includes only first-lien, owner-occupied home-purchase loans for 1-4 family homes.
1. For loans originated in 2008. Not applicable. properties. ${ }^{23}$ From 1996 through 2005, the share of one- to four-family, site-built home purchase loans for non-owner-occupied properties rose each year, increasing from 6.4 percent to 17.3 percent over the period (table 7). This share has since fallen to 13.5 percent in 2008 .

Currently, loans for non-owner-occupied properties are not eligible for the FHA or VA programs. However, the GSEs can purchase non-owner-occupied property loans that otherwise meet their requirements, but they typically demand interest rates that are about $3 / 8$ of a percentage point higher than the interest rates on loans for similar owner-occupied properties. Perhaps reflecting less of an appetite for such loans on the part of private lenders, the GSE market share of both home-purchase and refinance non-owneroccupied property lending grew about 10 percentage points from 2007 to 2008 (33.8 percent to 43.1 percent for home-purchase lending and 28.4 percent to 39.2 percent for refinance lending). Nevertheless, non-owner-occupied property lending remained a comparatively small part of overall GSE lending in 2008 (17.9 percent of home-purchase lending and 11.3 percent of refinance lending; data not shown in tables).

\section{Piggyback Lending}

Since the early 2000s, piggyback loans emerged as an important segment of the conventional mortgage market, particularly regarding loans to purchase homes.

23. An investment property is a non-owner-occupied dwelling that is intended to be rented or resold for a profit. Some non-owneroccupied units-vacation homes and second homes-are for the primary use of the owners and thus would not be considered investment properties. The HMDA data do not, however, distinguish between these two types of non-owner-occupied dwellings.
7. Non-owner-occupied lending as a share of all first liens to purchase or refinance one- to four-family, site-built homes, by number and dollar amount of loans, 19902008

Percent

\begin{tabular}{|c|c|c|c|c|}
\hline \multirow[b]{2}{*}{ Year } & \multicolumn{2}{|c|}{ Home purchase } & \multicolumn{2}{|c|}{ Refinance } \\
\hline & Number & $\begin{array}{c}\text { Dollar } \\
\text { amount }\end{array}$ & Number & $\begin{array}{r}\text { Dollar } \\
\text { amount }\end{array}$ \\
\hline 1990. & 6.6 & 5.9 & 9.0 & 8.4 \\
\hline 1991.. & 5.6 & 4.5 & 5.8 & 4.9 \\
\hline 1992. . & 5.2 & 4.0 & 4.7 & 4.0 \\
\hline 1993. . & 5.1 & 3.8 & 5.1 & 4.3 \\
\hline 1994.. & 5.7 & 4.3 & 8.0 & 6.6 \\
\hline $1995 \ldots$ & 6.4 & 5.0 & 7.8 & 6.4 \\
\hline 1996. & 6.4 & 5.1 & 6.7 & 5.8 \\
\hline 1997. . & 7.0 & 5.8 & 6.8 & 5.7 \\
\hline 1998. & 7.1 & 6.0 & 5.2 & 4.4 \\
\hline 1999. & 7.4 & 6.4 & 6.7 & 5.9 \\
\hline 2000. & 8.0 & 7.2 & 7.4 & 7.0 \\
\hline $2001 \ldots$ & 8.6 & 7.6 & 5.8 & 5.2 \\
\hline 2002. . & 10.5 & 9.2 & 6.1 & 5.3 \\
\hline 2003. . & 11.9 & 10.6 & 6.2 & 5.6 \\
\hline 2004 . & 14.9 & 13.1 & 8.3 & 7.2 \\
\hline 2005. & 17.3 & 15.7 & 8.8 & 7.9 \\
\hline 2006. . & 16.5 & 14.8 & 10.7 & 9.9 \\
\hline $2007 .$. & 14.9 & 13.8 & 11.3 & 10.6 \\
\hline $2008 \ldots$ & 13.5 & 12.3 & 10.0 & 9.5 \\
\hline
\end{tabular}

In piggyback lending, borrowers simultaneously receive a first-lien mortgage and a junior-lien (piggyback) loan. The piggyback loan finances the portion of the purchase price not being financed by the first mortgage and sometimes any cash payment that might have been made; the junior-lien loan may amount to as much as 20 percent of the purchase price. In many cases, borrowers used piggyback loans to avoid the need to obtain PMI. ${ }^{24}$ Sometimes, piggyback loans were used to keep the size of the first-lien

24. One advantage of piggyback loans over those backed by PMI insurance was that PMI payments made by the borrower did not qualify as deductible interest under Internal Revenue Service (IRS) guidelines, whereas interest payments on many piggyback loans did. 
8. Piggyback home-purchase lending, 2004-08

\begin{tabular}{|c|c|c|c|c|}
\hline \multirow{2}{*}{ Year } & \multirow{2}{*}{ Number } & \multirow{2}{*}{ Incidence } & \multicolumn{2}{|c|}{ Мемо } \\
\hline & & & $\begin{array}{c}\text { Higher-priced proportion } \\
\text { of piggyback loans }\end{array}$ & $\begin{array}{l}\text { Piggyback proportion of } \\
\text { higher-priced loans }\end{array}$ \\
\hline $2004 \ldots$ & 530,740 & 12.9 & 19.1 & 22.5 \\
\hline $2005 \ldots$ & 950,965 & 21.5 & 53.2 & 46.7 \\
\hline 2006 . . & 950,408 & 24.3 & 44.4 & 42.8 \\
\hline $2007 \ldots$ & 356,959 & 12.2 & 16.0 & 13.9 \\
\hline $2008 \ldots$ & 43,017 & 2.7 & 3.0 & 1.1 \\
\hline
\end{tabular}

NotE: Conventional first-lien mortgages for owner-occupied, 1-4 family, site-built properties.

loan within the Fannie Mae and Freddie Mac conforming loan limits so the borrower could take advantage of the lower interest rates available on conforming loans.

The HMDA data help document the extent of piggyback lending over time. However, because not all lenders submit HMDA data, some of the juniorlien loans that are reported may not have the corresponding first-lien loan reported, and some of the first-lien loans that are reported may not have the associated junior-lien loan reported. Also, some piggyback loans may be open-end loans that do not need to be reported under HMDA.

The HMDA data for 2005 and 2006 show that lenders extended about 1.2 million junior-lien loans to help individuals purchase one- to four-family, site built homes for owner-occupied properties in each of these years. The number of reported junior-lien loans contracted sharply in 2007 to about 550,000 such loans. This contraction continued as the number of junior-lien loans declined by 83 percent from the 2007 level to only about 92,000 loans in 2008 .

A loan-matching process can be undertaken to determine which reported junior-lien loans in the HMDA data appear to be associated with the appropriate reported first-lien loans. ${ }^{25}$ Our matching algorithm indicates that in 2008, 2.7 percent of the nearly 1.6 million first-lien conventional loans to purchase one- to four-family, site-built owner-occupied homes involved a piggyback loan reported by the same lender, a proportion that was down 77 percent from 2007 (table 8).

The Congress allowed the deductibility of PMI premiums of some borrowers starting in 2007, which reduced the relative attractiveness of piggybacks.

25. For the analysis here, a junior-lien loan was identified as a piggyback loan to a reported first-lien loan if both loans (1) were conventional loans involving property in the same census tract; (2) were originated by the same lender with approximately the same dates of loan application and closing; and (3) had the same owneroccupancy status and identical borrower income, race or ethnicity, and sex.

\section{THE DISPOSITION OF APPLICATIONS BY LOAN CHARACTERISTICS IN 2008}

Thus far, our analysis of the HMDA data has focused primarily on how the mortgage market has evolved over the past few years. In this section, we examine the information provided by HMDA about what home lending looked like in 2008.

Table 9 categorizes every loan application reported in 2008 into 25 distinct product categories characterized by loan and property type, purpose of the loan, and lien and owner-occupancy status. Each product category contains information on the number of total applications, application denials, originated loans, loans with prices above the reporting thresholds established by HMDA reporting rules for identifying higher-priced loans, loans covered by the Home Ownership and Equity Protection Act (HOEPA), and the mean and median APR spreads for loans reported as higher priced. ${ }^{26}$

The 2008 HMDA data include information on 14 million loan applications, about 12 million of which were acted upon by the lender. The vast majority of these applications were for first-lien loans on one- to four-family, site-built homes. Among these applications, about two-thirds of home-purchase applications and four-fifths of refinance applications were for conventional loans. These shares of applications for conventional loans are considerably lower than were observed in earlier years (data not shown in tables).

26. The type of information provided in tables 9 and 10 is identical to that provided in analyses of earlier years of HMDA data. Comparisons of the numbers in these two tables with earlier years can be made by consulting the following articles: Robert B. Avery, Kenneth P. Brevoort, and Glenn B. Canner (2008), "The 2007 HMDA Data," Federal Reserve Bulletin, vol. 94, pp. A107-A146; Robert B. Avery, Kenneth P. Brevoort, and Glenn B. Canner (2007), "The 2006 HMDA Data," Federal Reserve Bulletin, vol. 93, pp. A73-A109; Robert B. Avery, Kenneth P. Brevoort, and Glenn B. Canner (2006), "HigherPriced Home Lending and the 2005 HMDA Data," Federal Reserve Bulletin, vol. 92, pp. A123-A166; and Avery, Canner, and Cook, "New Information Reported under HMDA." 
9. Disposition of applications for home loans, and origination and pricing of loans, by type of home and type of loan, 2008

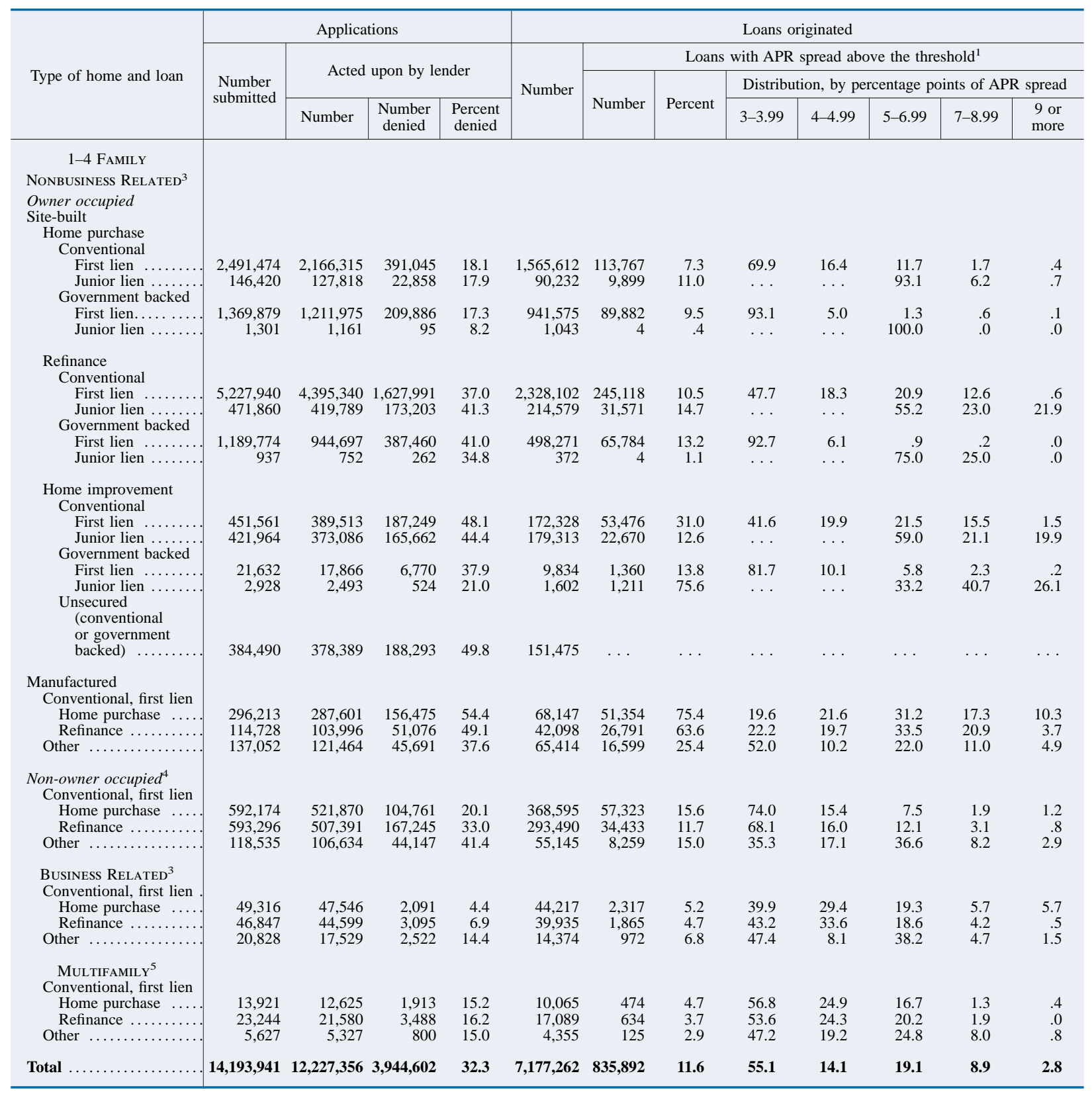

1. Annual percentage rate (APR) spread is the difference between the APR on the loan and the yield on a comparable-maturity Treasury security. The threshold for first-lien loans is a spread of 3 percentage points; for junior-lien loans, it is a spread of 5 percentage points.

2. Loans covered by the Home Ownership and Equity Protection Act of 1994 (HOEPA), which does not apply to home-purchase loans.

3. Business-related applications and loans are those for which the lender reported that the race, ethnicity, and sex of the applicant or co-applicant are not applicable; all other applications and loans are nonbusiness related.

4. Includes applications and loans for which occupancy status was missing

5. Includes business-related and nonbusiness-related applications and loans for owner-occupied and non-owner-occupied properties.

. . Not applicable.
Patterns in the denial rates are consistent with what has been observed in earlier years. Denial rates on applications for home-purchase loans are generally lower than those observed for either refinance or home-improvement loans. Denial rates on appli- cations backed by manufactured housing are generally higher than those backed by site-built homes.

Furthermore, requests for a first-lien, conventional, home-purchase loan backed by a manufactured home 
9. Disposition of applications for home loans, and origination and pricing of loans, by type of home and type of loan, 2008 — Continued

\begin{tabular}{|c|c|c|c|}
\hline \multirow{4}{*}{ Type of home and loan } & \multicolumn{3}{|c|}{ Loans originated } \\
\hline & \multicolumn{3}{|c|}{ Loans with APR spread above the threshold ${ }^{1}$} \\
\hline & \multicolumn{2}{|c|}{ APR spread (percentage points) } & \multirow{2}{*}{ Number of HOEPA-covered loans ${ }^{2}$} \\
\hline & Mean & Median & \\
\hline \multicolumn{4}{|l|}{$\begin{array}{l}1-4 \text { FAMILY } \\
\text { NONBUSINESS RELATED }\end{array}$} \\
\hline \multirow{2}{*}{\multicolumn{4}{|c|}{ Site-built }} \\
\hline & & & \\
\hline \multicolumn{4}{|l|}{$\begin{array}{r}\text { Home purchase } \\
\text { Conventional }\end{array}$} \\
\hline First lien ... & 3.9 & 3.5 & \\
\hline Junior lien ........ & 5.7 & 5.5 & \\
\hline \multicolumn{4}{|l|}{ Government backed } \\
\hline First lien $\ldots \ldots \ldots$ & 3.4 & 3.2 & \\
\hline Junior lien . & 5.9 & 5.7 & \\
\hline \multicolumn{4}{|l|}{ Refinance } \\
\hline \multicolumn{4}{|l|}{ Conventional } \\
\hline First lien ......... & 4.7 & 4.1 & 2,686 \\
\hline \multirow{2}{*}{\multicolumn{3}{|c|}{ Government backed }} & 873 \\
\hline & & & 583 \\
\hline Junior lien .......... & 6.2 & 5.8 & 0 \\
\hline \multicolumn{4}{|l|}{ Home improvement } \\
\hline Conventional & & & \\
\hline First lien ... & 5.0 & 4.4 & 1,085 \\
\hline \multirow{2}{*}{\multicolumn{4}{|c|}{ Government backed }} \\
\hline & & & \\
\hline First lien .......... & 3.7 & 3.3 & 8 \\
\hline Junior lien $\ldots \ldots \ldots \ldots \ldots \ldots \ldots$ & 7.8 & 7.7 & 27 \\
\hline \multicolumn{4}{|l|}{$\begin{array}{l}\text { Unsecured } \\
\text { (conventional or government backed)....... }\end{array}$} \\
\hline \multicolumn{4}{|l|}{ Manufactured } \\
\hline Conventional, first lien & & & \\
\hline Home purchase ..... & 6.0 & 5.5 & \\
\hline Refinance............. & 5.7 & 5.5 & 1,650 \\
\hline Other......... & 4.9 & 3.9 & 614 \\
\hline \multicolumn{4}{|l|}{ Non-owner occupied ${ }^{4}$} \\
\hline \multicolumn{4}{|l|}{ Conventional, first lien } \\
\hline Home purchase ..... & 3.9 & 3.5 & \\
\hline Refinance............ & 4.0 & 3.6 & 128 \\
\hline Other $\ldots \ldots \ldots \ldots \ldots+\ldots \ldots \ldots$ & 5.1 & 4.8 & 76 \\
\hline \multicolumn{4}{|l|}{$\begin{array}{l}\text { BusINESS RELATED } \\
\end{array}$} \\
\hline $\begin{array}{l}\text { Conventional, first lien } \\
\text { Home purchase } \ldots \ldots \ldots \ldots \ldots \ldots\end{array}$ & 4.9 & 4.3 & \\
\hline Refinance......................... & 4.4 & 4.2 & 4 \\
\hline Other............................ & 4.6 & 4.2 & 3 \\
\hline \multicolumn{4}{|l|}{$\begin{array}{l}\text { Multifamily }^{5} \\
\text { Muntion }\end{array}$} \\
\hline $\begin{array}{l}\text { Conventional, first lien } \\
\text { Home purchase ............ }\end{array}$ & 4.2 & 3.8 & \\
\hline Refinance.................... & 4.2 & 3.9 & 0 \\
\hline Other........................ & 4.6 & 4.1 & 2 \\
\hline Total & 4.6 & 3.8 & 8,593 \\
\hline
\end{tabular}

is the only one of the 25 product categories for which the majority of applications are denied.

In addition to the application data provided under HMDA, about 734,000 requests for preapprovals that were acted on by the lender were reported under HMDA (table 10). Almost one-quarter of these requests for preapproval were denied by the lender. Of the applications acted on by the lender and preceded by requests for preapproval, more than 88 percent were approved (data derived from table 10).

The HMDA data also indicate which loans were covered by HOEPA. Under HOEPA, certain types of mortgage loans that have rates or fees above speci- fied levels require additional disclosures to consumers and are subject to various restrictions on loan terms. ${ }^{27}$ For 2008, 2,281 lenders reported extending about 8,600 loans covered by HOEPA (data regarding lenders not shown in tables). In comparison,

27. The requirement to report HOEPA loans in HMDA relates to whether the loan is subject to the original protections of HOEPA, as determined by the coverage test in the Federal Reserve Board's Regulation Z, 12 C.F.R. pt. 226.32(a). The required reporting is not triggered by the more recently adopted protections for "higher-priced mortgage loans" under Regulation Z, notwithstanding that those protections were adopted under authority given to the Board by HOEPA. See 73 Fed. Reg. 44522 (July 30, 2008). The more recent HOEPA regulations do not take effect until October 1, 2009. 
10. Home-purchase lending that began with a request for preapproval: Disposition and pricing, by type of home, 2008

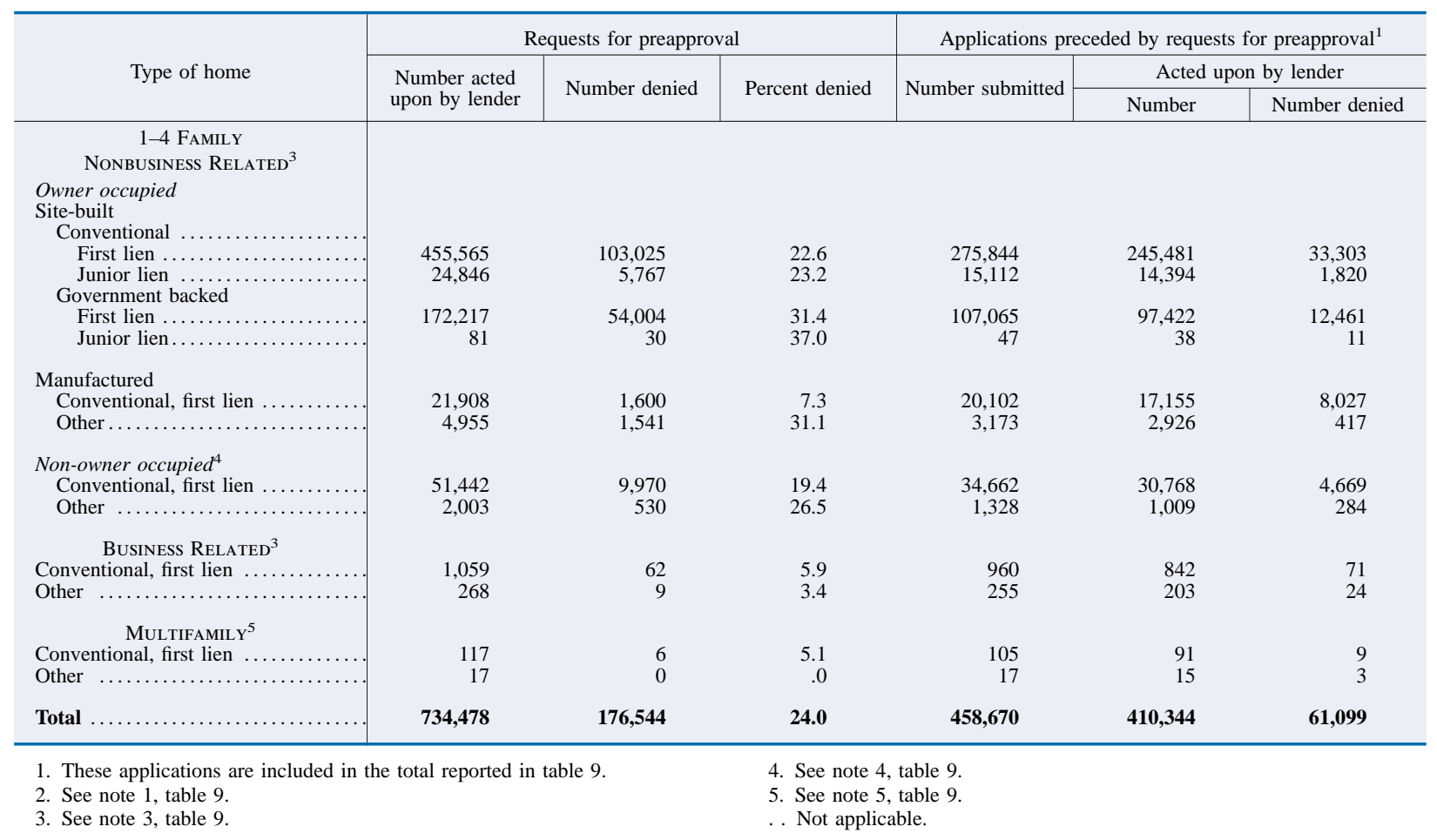

lenders reported on about 11,500 loans covered by HOEPA in 2007. In the aggregate, HOEPA-related lending made up less than 0.2 percent of all the originations of home-secured refinance mortgages and home-improvement loans reported for 2008 (data derived from table 9). ${ }^{28}$

Relative to previous years, a smaller proportion of loans were reported as higher priced in 2008, and a larger proportion of reported higher-priced loans had an APR less than 1 percentage point above the reporting threshold. Furthermore, a substantial fraction of loans in 2008 were likely reported as higher priced because of atypical changes in the interest rate environment, rather than because the loans represented relatively high credit risk. We discuss this issue in detail in the next section and formulate an adjusted measure of higher-priced loans that is more consistent over time.

\section{THE 2008 HMDA DATA ON LOAN PRICING}

A number of factors can alter the incidence of reported higher-priced lending without any corresponding changes in subprime lending activity. In 2008, we identify two factors related to the overall interest rate environment-a steepening of the yield curve and widening spreads between Treasury rates

28. HOEPA does not apply to home-purchase loans. and the interest rates on prime mortgage loans-that may have led to variation over time in whether a loan was reported as higher priced in HMDA. Understanding how these changes in the interest rate environment affected the reported incidence of higher-priced lending is important when attempting to draw inferences about how lending to high-risk borrowers has changed.

In the following sections, we discuss how changes in the interest rate situation during 2007 and 2008 may have affected the reported incidence of higherpriced lending. We then present the methodology we use to adjust for changes in the interest rate environment in a manner that provides a clearer picture of how home lending to high-credit-risk borrowers has changed. We then discuss what the 2008 HMDA data indicate about lending to high-risk borrowers.

\section{How the Interest Rate Situation Affected the Reporting of Higher-Priced Loans}

The reporting rules governing HMDA require lenders to use the yield on a Treasury security with a comparable term to maturity in determining whether a loan was required to be reported as higher priced under HMDA. Because most mortgages prepay well before the stated term of the loan, lenders typically use relatively shorter-term interest rates when setting the price of mortgage loans. For example, lenders often 
10. Home-purchase lending that began with a request for preapproval: Disposition and pricing, by type of home, 2008—Continued

\begin{tabular}{|c|c|c|c|c|c|c|c|c|c|c|}
\hline \multirow{4}{*}{ Type of home } & \multicolumn{10}{|c|}{ Loan originations whose applications were preceded by requests for preapproval } \\
\hline & \multirow{3}{*}{ Number } & \multicolumn{9}{|c|}{ Loans with APR spread above the threshold ${ }^{2}$} \\
\hline & & \multirow{2}{*}{ Number } & \multirow{2}{*}{ Percent } & \multicolumn{5}{|c|}{ Distribution, by percentage points of APR spread } & \multicolumn{2}{|c|}{$\begin{array}{l}\text { APR spread (percentage } \\
\text { points) }\end{array}$} \\
\hline & & & & 3-3.99 & $4-4.99$ & $5-6.99$ & $7-8.99$ & 9 or more & Mean spread & $\begin{array}{c}\text { Median } \\
\text { spread }\end{array}$ \\
\hline \multicolumn{11}{|l|}{$\begin{array}{c}\text { 1-4 FAMILY } \\
\text { NONBUSINESS RELATED }\end{array}$} \\
\hline $\begin{array}{l}\text { Owner occupied } \\
\text { Site-built }\end{array}$ & & & & & & & & & & \\
\hline First lien ... & 190,583 & 6,881 & 3.6 & 84.6 & 11.4 & 3.4 & .4 & .1 & 3.5 & 3.3 \\
\hline Junior lien ....... & 10,987 & 1,279 & 11.6 & $\ldots$ & $\ldots$ & 97.3 & 2.7 & .1 & 5.6 & 5.4 \\
\hline \multicolumn{11}{|l|}{ Government backed } \\
\hline First lien ......... & 80,369 & 7,844 & 9.8 & 94.4 & 4.9 & .5 & .1 & .1 & 3.4 & 3.2 \\
\hline Junior lien.... & 27 & 1 & 3.7 & $\ldots$ & $\ldots$ & 100.0 & .0 & .0 & 5.8 & 5.8 \\
\hline \multicolumn{11}{|l|}{ Manufactured } \\
\hline Conventional, first lien & 6,928 & 4,592 & 66.3 & 12.6 & 21.4 & 40.6 & 19.5 & 5.9 & 6.0 & 6.0 \\
\hline Other $\ldots \ldots \ldots \ldots \ldots$ & 2,293 & 594 & 25.9 & 86.7 & 8.1 & 4.4 & .8 & .0 & 3.6 & 3.3 \\
\hline \multicolumn{11}{|l|}{ Non-owner occupied ${ }^{4}$} \\
\hline Conventional, first lien & 23,382 & 2,086 & 8.9 & 82.2 & 12.4 & 3.8 & 1.0 & 6 & 3.7 & 3.4 \\
\hline Other $\ldots \ldots \ldots \ldots \ldots$ & 646 & 33 & 5.1 & 24.2 & .0 & 72.7 & 3.0 & .0 & 5.0 & 5.2 \\
\hline \multicolumn{11}{|l|}{ Business Related ${ }^{3}$} \\
\hline Conventional, first lien & 731 & 53 & 7.3 & 50.9 & 32.1 & 15.1 & 1.9 & .0 & 4.2 & 3.9 \\
\hline Other $\ldots \ldots \ldots \ldots \ldots$ & 172 & 15 & 8.7 & 86.7 & 13.3 & .0 & .0 & .0 & 3.4 & 3.2 \\
\hline \multicolumn{11}{|l|}{ Multifamily $^{5}$} \\
\hline Conventional, first lien & 71 & 1 & 1.4 & .0 & .0 & 100.0 & .0 & .0 & 6.0 & 6.0 \\
\hline Other $\ldots \ldots \ldots \ldots \ldots$ & 11 & 1 & 9.1 & 100.0 & .0 & .0 & .0 & .0 & 3.0 & 3.0 \\
\hline Total & 316,200 & 23,380 & 7.4 & 68.8 & 10.6 & 15.1 & 4.2 & 1.3 & 4.1 & 3.5 \\
\hline
\end{tabular}

price 30-year fixed-rate mortgages based on the yields on securities with maturities of fewer than 10 years, and they typically set interest rates on adjustable-rate mortgages (ARMs) on the basis of securities with much shorter terms. Thus, a change in the relationship between shorter-term and longer-term yields can affect the reported incidence of higher-priced lending. For example, if short-term interest rates fall relative to long-term rates, then the number and proportion of loans reported as higher priced will fall even if other factors, such as lenders' underwriting practices or borrowers' characteristics, are unchanged. For ARMs, this effect is further exacerbated by the manner in which APRs are calculated. The interest rates on most ARM loans, after the initial interest rate reset date, are typically set based on interest rates for one-year securities. As a result, the APRs for ARMs-which take into account the expected interest rates on a loan, assuming that the loan does not prepay and that the index rates used to establish interest rates after the reset do not change-will be particularly sensitive to changes in one-year interest rates. Consequently, higher-priced lending reported for ARMs will fall when one-year interest rates decline relative to other rates even if the relationship between long-term and intermediate-term rates is constant.

The relationship between shorter- and longer-term interest rates can be seen in the yield curve for
Treasury securities, which displays how the yields on these securities vary with the term to maturity. Through the first seven months of 2007, the yield curve was relatively flat and then began to steepen, so that the differences between the yield on a 30-year Treasury security and the yields on the five-year and one-year Treasury securities increased (figure 2). Overall, this steepening continued in 2008; while

2. Spread between interest rates on 30-year and 5-year as well as 30-year and 1-year Treasury bonds, 2006-08

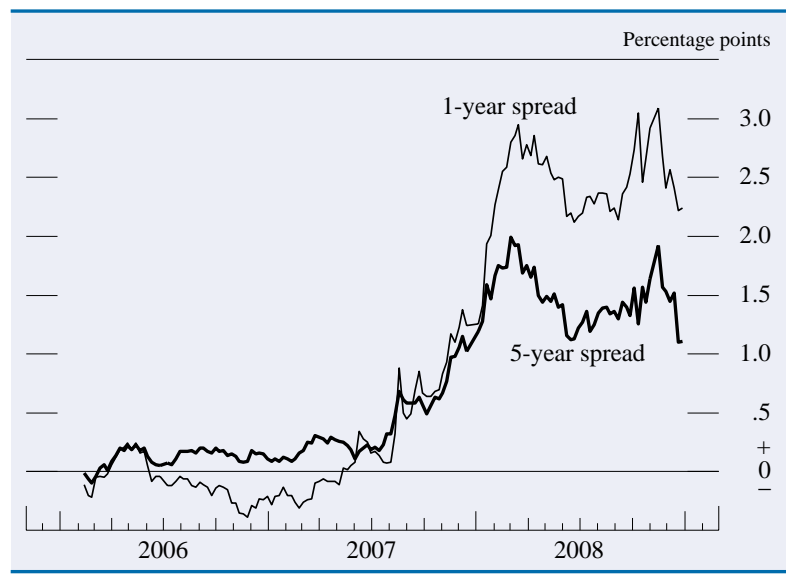

Note: The data are weekly. Prior to mid-February 2006, the 30-year Treasury bond was not available, and the data are missing.

SourCE: Federal Reserve Board, Statistical Release H.15, www.federalreserve.gov/releases/h15/data.htm. 
3. HMDA price-reporting threshold, interest rates for fixedand adjustable-rate loans, and spreads between the threshold and such rates, 2006-08

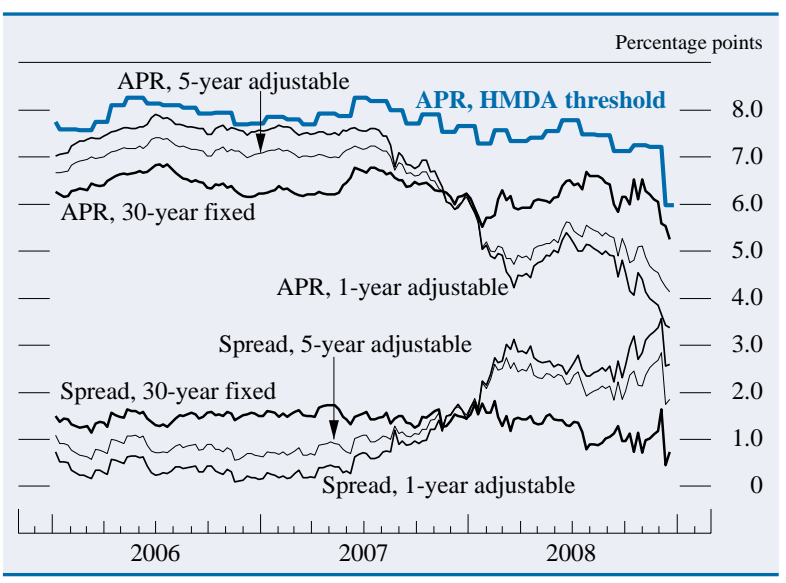

NotE: For explanation of Home Mortgage Disclosure Act (HMDA) price-reporting threshold, see text. The threshold and annual percentage rates (APRs) are for conventional first-lien 30-year prime loans.

Source: APRs from the Freddie Mac Primary Mortgage Market Survey; see notes to figure 1 .

spreads did narrow during the spring and at the very end of 2008, they remained consistently above the spreads observed in 2007. As discussed earlier, this change would be expected to decrease the incidence of reported higher-priced lending, particularly for ARMs, even in the absence of any changes in highrisk lending activity.

In addition to the steepening yield curve, a second change in the interest rate environment affected the likelihood that a loan was reported as higher priced in HMDA in 2008. As a result of the "flight to quality" and liquidity concerns caused by the financial crisis late in 2008, the spreads between the yields on Treasury securities and other securities and loans, including 30-year fixed-rate loans, widened considerably. At the beginning of 2008, the HMDA reporting threshold was 7.66 percent, and the APR on a 30 -year fixed-rate prime loan, based on the rates reported by Freddie Mac's Primary Mortgage Market Survey (PMMS), was 6.12 percent (figure 3).29 This difference resulted in a gap between the HMDA reporting threshold and the APR on a prime 30-year fixed-rate loan of 1.54 percentage points.

29. The weekly Freddie Mac Primary Mortgage Market Survey reports the average contract interest rates and discount points for all loans and the margin for adjustable-rate loans for loans offered to prime borrowers (those with the lowest credit risk). The survey currently reports information for two fixed-rate mortgage products (30 year and 15 year) and two ARM products (one-year adjustable rate and a five-year adjustable rate). For more information, see www.freddiemac.com/dlink/html/PMMS/display/ PMMSOutputYr.jsp.
By the end of 2008, this gap had narrowed to approximately 0.77 percentage points, as the falling yields on Treasury securities pulled the HMDA reporting threshold closer to the prime mortgage rate. As a result, an increasing share of near-prime loans would have been reported as higher priced toward the end of 2008 over what had been reported earlier in the year. Widening spreads between the interest rates on Treasury securities and the rates on prime mortgage loans would be expected to increase the overall incidence of higher-priced lending, even if the creditrisk profile of borrowers remained unchanged.

These two changes in the interest rate environment in 2008, therefore, worked in opposite directions. The expected net effect of these two competing forces can be discerned from figure 3 . The top line in that figure shows the HMDA reporting threshold in effect from 2006 through 2008. The middle three lines show the APRs calculated from the interest rates reported in Freddie Mac's PMMS for the three 30-year loan products reported in that survey: a fixed-rate loan, a 5-year ARM, and a 1-year ARM. As expected, the steepening of the yield curve had a much larger effect on the APRs associated with ARMs than on fixed-rate loans, though rates on all three products were generally lower in 2008 than they had been in earlier years.

The change during 2008 in the spreads between the APRs on these prime loans and the HMDA reporting threshold (shown by the bottom three lines in figure 3) suggests that the net effect of these changes depended on whether the loan had a fixed or adjustable rate. For ARMs, the spreads appeared to have widened substantially in 2008, suggesting that the incidence of reported higher-priced lending for these loans should have decreased in 2008 even without changes in borrower characteristics. For fixed-rate loans, spreads appear to have narrowed relative to earlier years. Consequently, the incidence of reported higher-priced lending for fixed-rate loans should have increased.

The difference in the net effects of the changes in the interest rate environment between fixed- and adjustable-rate loans complicates an analysis of the HMDA data, because one cannot determine whether a loan in the HMDA data is a fixed- or adjustable-rate loan. Using industry data, however, it is possible to estimate the monthly volume of both loan types. ${ }^{30}$ These data show that at the beginning of 2007, ARMs

30. Source: Lender Processing Services, Inc. (LPS). LPS claims coverage of about 70 percent of the mortgage market, including all loans of 9 of the top 10 mortgage servicers (see www.lpsvcs.com). Their coverage is nonrandom and appears to overrepresent governmentrelated lending and underrepresent jumbo and subprime lending. 
11. Share of mortgage originations, by type and length of loan and by month of closing, 2006-08 Percent

\begin{tabular}{|c|c|c|c|c|c|c|}
\hline Year & Month & $\begin{array}{l}\text { 30-year } \\
\text { FRM }\end{array}$ & 15-year FRM & $\begin{array}{c}\text { Less than } \\
\text { 5-year ARM }\end{array}$ & $\begin{array}{c}5 \text {-year or } \\
\text { longer ARM }\end{array}$ & Total \\
\hline 2006 & $\begin{array}{l}\text { January } \\
\text { February } \\
\text { March } \\
\text { April } \\
\text { May } \\
\text { June } \\
\text { July } \\
\text { August } \\
\text { September } \\
\text { October } \\
\text { November } \\
\text { December }\end{array}$ & $\begin{array}{l}55.9 \\
58.4 \\
58.7 \\
59.7 \\
59.1 \\
59.4 \\
58.4 \\
60.6 \\
63.7 \\
65.2 \\
69.8 \\
71.6\end{array}$ & $\begin{array}{r}10.1 \\
10.1 \\
9.0 \\
8.1 \\
7.3 \\
6.8 \\
6.7 \\
6.9 \\
7.5 \\
7.9 \\
7.8 \\
7.9\end{array}$ & $\begin{array}{r}16.7 \\
14.6 \\
15.8 \\
16.0 \\
16.7 \\
15.6 \\
17.4 \\
16.5 \\
13.5 \\
12.3 \\
10.5 \\
8.9\end{array}$ & $\begin{array}{l}17.3 \\
17.0 \\
16.5 \\
16.2 \\
17.0 \\
18.2 \\
17.6 \\
15.9 \\
15.3 \\
14.6 \\
11.9 \\
11.6\end{array}$ & $\begin{array}{l}100 \\
100 \\
100 \\
100 \\
100 \\
100 \\
100 \\
100 \\
100 \\
100 \\
100 \\
100\end{array}$ \\
\hline 2007 & $\begin{array}{l}\text { January } \\
\text { February } \\
\text { March } \\
\text { April } \\
\text { May } \\
\text { June } \\
\text { July } \\
\text { August } \\
\text { September } \\
\text { October } \\
\text { November } \\
\text { December }\end{array}$ & $\begin{array}{l}73.8 \\
75.8 \\
77.6 \\
79.0 \\
79.7 \\
79.8 \\
77.3 \\
77.7 \\
83.2 \\
83.4 \\
82.5 \\
82.5\end{array}$ & $\begin{array}{r}8.4 \\
8.0 \\
7.9 \\
8.4 \\
8.1 \\
7.5 \\
7.1 \\
7.3 \\
7.9 \\
8.8 \\
9.0 \\
10.1\end{array}$ & $\begin{array}{l}7.4 \\
7.2 \\
4.8 \\
3.7 \\
3.5 \\
3.8 \\
4.5 \\
3.9 \\
2.3 \\
1.6 \\
1.5 \\
1.5\end{array}$ & $\begin{array}{r}10.4 \\
9.0 \\
9.7 \\
8.9 \\
8.8 \\
9.0 \\
11.1 \\
11.1 \\
6.5 \\
6.1 \\
7.1 \\
6.0\end{array}$ & $\begin{array}{l}100 \\
100 \\
100 \\
100 \\
100 \\
100 \\
100 \\
100 \\
100 \\
100 \\
100 \\
100\end{array}$ \\
\hline 2008 & $\begin{array}{l}\text { January } \\
\text { February } \\
\text { March } \\
\text { April } \\
\text { May } \\
\text { June } \\
\text { July } \\
\text { August } \\
\text { September } \\
\text { October } \\
\text { November } \\
\text { December }\end{array}$ & $\begin{array}{l}81.9 \\
76.1 \\
70.1 \\
71.2 \\
76.7 \\
75.4 \\
76.2 \\
75.7 \\
79.9 \\
84.0 \\
85.3 \\
88.4\end{array}$ & $\begin{array}{l}12.6 \\
17.8 \\
19.7 \\
20.7 \\
17.6 \\
15.6 \\
14.2 \\
14.5 \\
14.0 \\
13.4 \\
12.4 \\
10.4\end{array}$ & $\begin{array}{r}.9 \\
1.0 \\
1.9 \\
2.2 \\
1.2 \\
1.3 \\
1.5 \\
1.9 \\
1.7 \\
1.1 \\
1.0 \\
.6\end{array}$ & $\begin{array}{r}4.6 \\
5.1 \\
8.3 \\
5.8 \\
4.5 \\
7.6 \\
8.1 \\
7.8 \\
4.4 \\
1.5 \\
1.3 \\
.6\end{array}$ & $\begin{array}{l}100 \\
100 \\
100 \\
100 \\
100 \\
100 \\
100 \\
100 \\
100 \\
100 \\
100 \\
100\end{array}$ \\
\hline
\end{tabular}

Note: Restricted to conventional first liens for owner-occupied, 1-4 family, site-built properties.

FRM Fixed-rate mortgage.

ARM Adjustable-rate mortgage.

SOURCE: Lender Processing Services, Inc.

accounted for about 17.8 percent of the market, falling to a range of between 5 and 6 percent at the beginning of 2008 (table 11). During 2008, ARM activity continued to fall (particularly in the latter portion of the year) to less than 2 percent. Given the small share of ARMs in the marketplace in 2008, the majority of distortions in the incidence of reported higher-priced lending caused by changes in the interest rate environment can be attributed to fixed-rate lending.

\section{Adjusting for Changes in the Interest Rate Environment, 2006-08}

The changes in the interest rate environment discussed in the previous section can result in loans of a given level of credit risk being reported as higher priced in the HMDA data at some points in time but not others. This variation makes drawing inferences about changes in high-credit-risk lending based upon changes in the incidence of reported higher-priced lending much more complicated. To better isolate the credit-risk component of pricing so that we have a definition of a "higher-priced loan" that is more constant over time and, therefore, more fully reflective of high-risk lending activity, we construct an adjusted measure.

We define the credit-risk component of a loan as the difference between the APR on that loan and the APR available to the lowest-risk prime borrowers at that time. This credit-risk component is assumed to be constant over time. ${ }^{31}$ In other words, we assume that a nonprime borrower who received a loan with an APR that was 0.25 percentage points above the APR available to prime borrowers at that time would receive a loan that was 0.25 percentage points above the available rate for prime borrowers at all other times, regardless of any changes in the interest rate environment. We then examine the share of loans over time with credit-risk components above specific

31. The credit-risk component that we are defining here may include other risk components besides credit risk (for example, prepayment risk). 
thresholds. This approach should provide a more accurate depiction of how the extent of high-risk lending has changed that is relatively free of the distortions introduced in the incidence of reported higher-priced lending by changes in the interest rate environment.

In estimating the credit-risk component of loans in the HMDA data, we use, as the measure of the rate available to prime borrowers, the APR derived from the information reported in the Freddie Mac PMMS for a 30-year fixed-rate loan. ${ }^{32}$ As an approximation of the APR on loans in HMDA, we add the reported spread (for higher-priced loans) to the appropriate HMDA reporting threshold for a 30-year loan. We refer to the resulting estimate of the credit-risk component as the PMMS spread. ${ }^{33}$

PMMS spreads can only be calculated for loans with reported spreads in HMDA. Loans with PMMS spreads below 0.95 percentage points would not have been reported as higher priced at any time between 2006 and 2008. We are therefore unable to identify these loans in the data. Loans with PMMS spreads between 0.95 and 1.75 percentage points would have been reported as higher priced at some points during the three years but not at others, so we can only identify these loans at some points in time. Only those loans with a PMMS spread of more than 1.75 percentage points have been consistently identified in the HMDA data as higher priced. Therefore, we focus on loans with a PMMS spread greater than 1.75 percentage points in examining how high-risk lending has changed over time, as this measure should be free of the distortions introduced by changes in the interest rate environment and should more accurately reflect changes in high-risk lending activity over time. We refer to loans with a PMMS spread in excess of 1.75 percentage points as adjusted higher-priced loans.

32. By using the APR for the 30-year fixed-rate mortgage, we are implicitly treating all loans in the HMDA data as though they were 30 -year fixed rate loans. Because of the small market share for ARMs and the prevalence of 30-year loans, we do not expect this simplifying assumption to have a substantive effect on our analysis of 2008 data. However, note that the share of loans that were ARMs in 2006 and early 2007 was much higher than in 2008. As such, one should exercise caution when comparing incidences of adjusted higher-priced lending across these periods.

33. Under new rules adopted by the Federal Reserve Board in 2008, the spread between a loan's APR and the APR of comparable prime PMMS loan will be used to determine whether a loan is reported as higher priced in HMDA. The new rules take effect for all loans with application dates on or after October 1, 2009, and for loans regardless of application date if originated in 2010. APRs of first-lien loans with a PMMS-APR spread of 1.50 percentage points or more must be reported. For second-lien loans, the reporting threshold is a PMMSAPR spread of 3.50 percentage points.

\section{Incidence of Higher-Priced Lending}

As in earlier years, most loans reported in 2008 were not higher priced as defined under HMDA reporting rules. Among all the HMDA-reported loans secured by one- to four-family properties, 11.6 percent were higher priced in 2008 , down significantly from the historic high point of 28.7 percent in 2006 and from 18.3 percent in 2007 (data for 2008 shown in table 3; data for 2006 and 2007 are not shown in tables). The incidence of higher-priced lending fell from the 2007 levels for all conventional loan product categories, with the exception of those related to manufactured homes.

Looking exclusively at changes in the annual rates of higher-priced lending can obscure the information about how the mortgage market is developing over time. To better illustrate how changes in higher-priced lending have played out in recent years, we examine monthly patterns in higher-priced lending activity. The top line in the upper panel of figure 4 shows the incidence of reported higher-priced, home-purchase lending. The monthly data show that the overall annual decline in the incidence of higher-priced lending between 2007 and 2008 obscures a substantial rebound in the incidence of reported higher-priced lending in the second half of 2008. A similar rebound in the incidence of reported higher-priced lending is observed for the refinance loans (shown in the bottom panel of figure 4).

This rebound in the incidence of reported higherpriced lending appears to reflect changes in the interest rate environment and not changes in actual high-risk lending activity. Using our methodology to correct for distortions caused by changes in the interest rate environment, we see that the share of adjusted higher-priced loans (shown in figure 4 as "PMMS + 1.75") continued to decline in 2008 and remained at historically low levels, even when the incidence of reported higher-priced lending in HMDA began to increase. There does appear to have been something of a rebound in the share of adjusted higher-priced home-purchase loans at the very end of 2008, though, even after this increase, the incidence of adjusted higher-priced lending remained below the levels observed throughout 2007.

The pattern for refinance lending appears somewhat different than that for home-purchase lending. The incidence of adjusted higher-priced refinance lending fell at the beginning of 2008 and then remained relatively flat throughout the rest of the year. The timing of this decline, and the fact that a similar decline was not observed for home-purchase lending, suggests that this may be the result of a 
4. Higher-priced share of lending, by annual percentage rate threshold, 2006-08

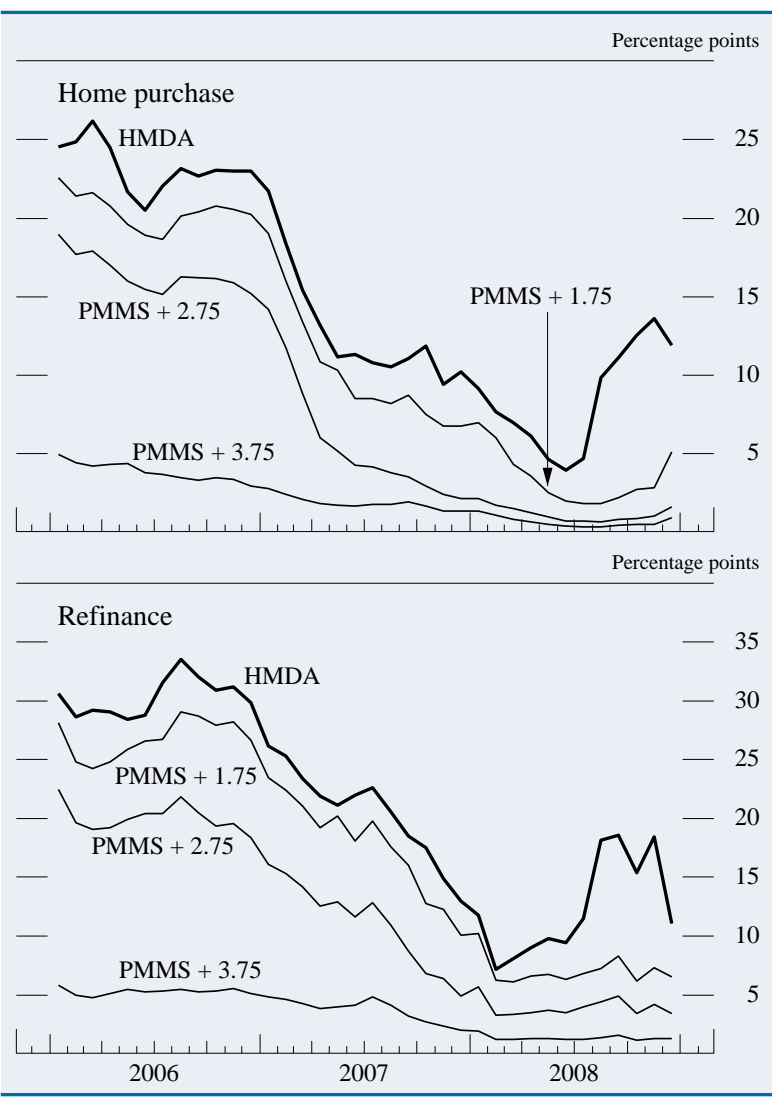

NotE: The data are monthly. Loans are first-lien mortgages for site-built properties and exclude business loans. Annual percentage rates are for conventional 30-year fixed-rate prime mortgages.

PMMS Freddie Mac Primary Mortgage Market Survey.

HMDA Home Mortgage Disclosure Act.

changing mix of borrowers caused by the refinancing boom in early 2008. This refinancing boom, which coincided with a sharp decline in the prime mortgage rate, may have encouraged a large number of highcredit-quality borrowers to refinance their prime mortgages in order to take advantage of relatively low mortgage rates. A tendency of high-credit-quality borrowers to refinance when rates are low and to refrain when rates are high may explain why the incidence of adjusted higher-priced refinancing lending exhibits more variation than home-purchase lending. A comparison of the incidence of adjusted higherpriced lending and volume of refinancing suggests that increases (decreases) in refinancing activity often occur at the same time as decreases (increases) in the incidence of adjusted higher-priced lending (figures 3 and 4).

Figure 4 also shows the share of home-purchase and refinance lending that was composed of loans with PMMS spreads of more than 2.75 percentage points (shown in the figure as "PMMS + 2.75") and more than 3.75 percentage points ("PMMS + 3.75"). Most of the adjusted higher-priced loans had PMMS spreads in excess of 2.75 percentage points for most of 2006. In 2007, this circumstance changed dramatically as the shares of both home-purchase and refinance lending accounted for by these loans fell precipitously. While starting 2008 from much lower levels than previous years, the share of loans made up of these loans that were very higher priced continued to fall in 2008, though the decline seems to have slowed somewhat. Nevertheless, loans with PMMS spreads in excess of 2.75 percentage points now account for a negligible share of home-purchase lending and for a very small share of refinance lending. This suggests that, as in 2007, the decline in the incidence of adjusted higher-priced lending has been greater for the highest-risk borrowers.

\section{Higher-Priced Lending by Lender Type}

Higher-priced lending activity can also differ by type of lender. Three types of lender are considered here: depository institutions, subsidiaries or affiliates of depository institutions, and independent mortgage companies. In 2006, independent mortgage companies originated almost one-half of all higher-priced loans and accounted for 31.7 percent of all first-lien loans (table 12). For that year, depository institutions accounted for a smaller share of higher-priced lending (26.8 percent of adjusted higher-priced lending) than independent mortgage companies.

Since 2006, the share of higher-priced loans originated by independent mortgage companies has fallen dramatically. Independent mortgage companies accounted for 18.2 percent of reported higher-priced loans in HMDA in 2008, down from 45.7 percent of such loans in 2006. When using the adjusted higherpriced loan definition, the decline has been even steeper (particularly between 2007 and 2008), with the share of higher-priced loans extended to independent mortgage companies falling to 11.9 percent.

The share of adjusted higher-priced loans originated by depository institutions has increased substantially from 26.8 percent in 2006 to 61.6 percent in 2008 , though the incidence of adjusted higher-priced lending has also fallen for depository institutions over this period from 14.7 percent to 5.6 percent. These numbers suggest that the increased share of adjusted higher-priced lending of depository institutions reflects the sharp decline in high-risk lending by independent mortgage companies and not an increased focus on high-risk lending by depository institutions. Some of the increased share for the depository insti- 
12. Distribution of reported higher-priced lending, by type of lender, and incidence at each type of lender, 2006-08

Percent except as noted

\begin{tabular}{|c|c|c|c|c|c|c|c|c|}
\hline \multirow[t]{2}{*}{ Type of lender } & \multicolumn{3}{|c|}{ Higher-priced loans } & \multicolumn{3}{|c|}{ Adjusted higher-priced loans ${ }^{1}$} & \multicolumn{2}{|c|}{$\begin{array}{l}\text { Memo: } \\
\text { All loans }\end{array}$} \\
\hline & Number & Distribution & Incidence & Number & Distribution & Incidence & Number & Distribution \\
\hline & \multicolumn{8}{|c|}{2006} \\
\hline Independent mortgage company & $1,287,869$ & 45.7 & 39.1 & $1,163,602$ & 47.7 & 35.3 & $3,292,281$ & 31.7 \\
\hline Depository & 802,125 & 28.5 & 18.0 & 653,985 & 26.8 & 14.7 & $4,455,331$ & 42.9 \\
\hline Affiliate or subsidiary of depository & 725,953 & 25.8 & 27.6 & 624,179 & 25.6 & 23.7 & $2,633,237$ & 25.4 \\
\hline \multirow[t]{2}{*}{ 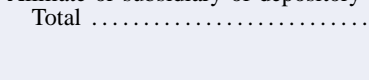 } & $2,815,947$ & 100 & 27.1 & $2,441,766$ & 100 & 23.5 & $10,380,849$ & 100 \\
\hline & \multicolumn{8}{|c|}{2007} \\
\hline Independent mortgage company & 306,675 & 21.1 & 18.2 & 264,893 & 21.7 & 15.7 & $1,685,948$ & 20.5 \\
\hline Depository $\ldots \ldots \ldots \ldots \ldots \ldots \ldots \ldots$ & 660,744 & 45.5 & 14.2 & 519,662 & 42.6 & 11.2 & $4,648,082$ & 56.5 \\
\hline Affiliate or subsidiary of depository & 485,287 & 33.4 & 25.7 & 436,425 & 35.7 & 23.1 & $1,888,347$ & 23.0 \\
\hline \multirow[t]{2}{*}{ 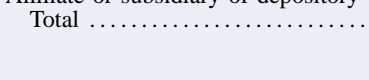 } & $1,452,706$ & 100 & 17.7 & $1,220,980$ & 100 & 14.8 & $8,222,377$ & 100 \\
\hline & \multicolumn{8}{|c|}{2008} \\
\hline Independent mortgage company & 120,605 & 18.2 & 9.1 & 43,894 & 11.9 & 3.3 & $1,319,714$ & 21.3 \\
\hline 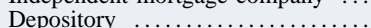 & 401,594 & 60.8 & 9.9 & 228,252 & 61.6 & 5.6 & $4,044,889$ & 65.3 \\
\hline Affiliate or subsidiary of depository & 138,709 & 21.0 & 16.8 & 98,232 & 26.5 & 11.9 & 826,848 & 13.4 \\
\hline 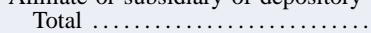 & 660,908 & 100 & 10.7 & 370,378 & 100 & 6.0 & $6,191,451$ & 100 \\
\hline
\end{tabular}

NoTE: First-lien mortgages for site-built properties; excludes business loans. For definition of higher-priced lending, see text.

1. Adjusted higher-priced loans are those with annual percentage rates

(APRs) 1.75 percentage points or more above the 30-year fixed-rate APR from the Freddie Mac Primary Mortgage Market Survey.

tutions may reflect acquisitions of previously independent mortgage companies.

\section{THE SURGE IN FHA AND VA LENDING}

Figure 5 illustrates the changing structure of the mortgage market between 2006 and 2008. It groups first-lien owner-occupied site-built mortgages for home purchase and refinance into six distinct categories: (1) loans sold to an affiliate or held in the portfolio of the originating lender ("Portfolio"), (2) loans sold into the private securitization market or to unaffiliated institutions ("Private"), (3) loans sold to Fannie Mae or Freddie Mac (GSEs), (4) loans insured by the FHA, (5) loans backed by the VA, and (6) loans insured by the Farm Service Agency or Rural Housing Service. The data show that approximately 40 percent of loans in early 2006 were sold into the private securitization market or to an unaffiliated institution. ${ }^{34}$ By the end of 2008, nearly one-half

34. Classifying loans by their ultimate disposition is complicated by HMDA reporting rules. A loan is classified as sold if the sale takes place within the HMDA reporting year. In other words, a loan originated in December must be sold within the same month to be classified as sold. Since lenders often hold loans for several months before selling them, there is an "underreporting" in loan sales in HMDA for loans originated toward the end of the year. Analysis of the HMDA data indicates that most loans are sold within three months if they were sold. To adjust for the underreporting in October-December, we used an imputation formula based on the allocation of loans originated in September (and the following January for 2006 and 2007 data) to allocate conventional loans among the first three groups shown in figure 5. Data in all of the tables presented in this section are based on this imputation. of home-purchase loans and one-quarter of refinance loans were backed by either the FHA or the VA, and fewer than 15 percent of originations were sold to unaffiliated institutions or into the private securitization market (however, recall table 4, which indicates that almost no loans were sold into the private securitization market in 2008). The two GSEs increased their market share in 2007, but then relinquished much of these gains during 2008.

While the decline of the subprime-based private securitization market was well under way by 2007 , FHA and VA lending did not surge until 2008. At least two events in early 2008 may help explain the timing of this surge. First, as part of the Economic Stimulus Act passed in February, the Congress authorized an increase in the loan-size limits applicable for the FHA and VA programs and GSE purchases. Second, beginning in the early part of 2008, PMI companies started limiting their issuance of insurance and raising prices because of rising claims and binding capital restrictions in certain states. As a consequence, Fannie Mae and Freddie Mac substantially reduced their purchases of loans with loan-to-value ratios (LTV) above 80 percent, which by statute require PMI (or other credit enhancement). Both GSEs also raised their credit guarantee fees for such loans at this time as well. We examine the effects of these events in the following two sections. 
5. Adjusted share of owner-occupied first-lien lending, by type of loan, 2006-08

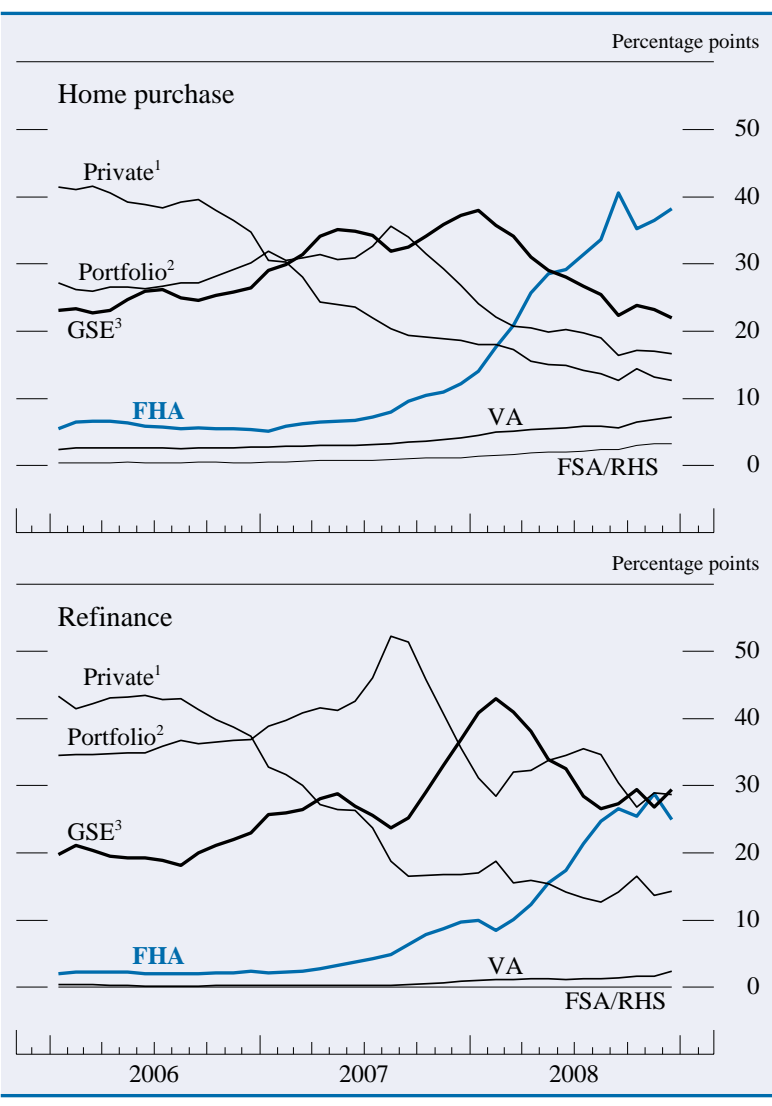

NotE: The data are monthly. Loans are for site-built properties and exclude business loans. For each year, the fourth quarter is adjusted for the government-sponsored entity (GSE), private, and portfolio loans. See text note 34 for details.

1. Private loans are conventional loans sold to a nongovernment-related or non-affiliate institution.

2. Portfolio loans are conventional loans held by the lender or sold to an affiliate institution.

3. GSE loans are all originations categorized as conventional and sold to Fannie Mae, Freddie Mac, Ginnie Mae, or Farmer Mac.

FHA Federal Housing Administration-insured.

VA Department of Veterans Affairs-guaranteed.

FSA/RHS Farm Service Agency or Rural Housing Service-guaranteed.

\section{The Effect of Higher Loan-Size Limits}

New standards released on March 6, 2008, raised the GSE and FHA loan-size limits up to $\$ 729,750$ in certain areas designated by the Department of Housing and Urban Development as "high cost." 35 FHA loan limits were also raised above their 2007 levels in many other areas to new levels. Prior to these changes, the GSEs could not purchase single-family home loans above $\$ 417,000$ in most states, while

35. More than one-half of the 2008 loans in the high-cost areas were in California. One-third of the loans were in the mid-Atlantic states of New York, New Jersey, Maryland, and Virginia. the FHA could not insure single-family home loans above $\$ 271,050$ in most areas of the country. ${ }^{36}$

VA loans do not have a size limit, but they do have a guarantee limit that is tied to GSE loan limits. ${ }^{37}$ The VA guarantees the smaller of 25 percent of the loan amount or 25 percent of the applicable GSE loan limit. As such, increases to the GSE loan limit raise the maximum VA guarantee amount.

To understand the potential effect of the higher limits, we divided loans originated in 2008 into four categories based on the size of the loan and the location of the property securing the loan: (1) loans smaller than the applicable 2007 FHA limit; (2) loans larger than the applicable 2007 FHA loan limit, but less than $\$ 417,000$ and the applicable 2008 FHA limit; (3) loans larger than $\$ 417,000$ but under the 2008 high-cost area limit common to the FHA, VA, and GSEs; and (4) all other loans. Changes in the loan-size limits directly affected the options available to borrowers for loans in categories 2 and 3 but did not affect those in categories 1 and 4 .

Table 13 displays the share of loans in these four categories by month, loan purpose, and loan product type (FHA, VA, GSE, and other). ${ }^{38}$ Among FHA loans, there is a noticeable rise in the share of "newly FHA-eligible" loans (categories 2 and 3) in the first half of the year when the limits were increased for both home-purchase and refinance loans. For 2008 overall, the share of FHA-insured home-purchase loans in categories 2 and 3 was 9.7 percent, compared with 2.4 percent in 2007.39 This increase implies that the limit changes lifted FHA home-purchase lending by 7.4 percent in 2008 ,

36. The GSE loan limits were higher in Alaska and Hawaii; the maximum loan size for the FHA program was as low as \$201,160 in some low-cost areas.

37. VA loans larger than the GSE limits, however, cannot be sold into Ginnie Mae security pools.

38. The other category includes portfolio loans, private loans, and loans insured by the Farm Service Agency or the Rural Housing Service (a very small part of the category).

Loan growth during 2008 (particularly for the first half of the year), shown in table 13, is likely understated because of the omission of data from the 15 lenders who failed to report HMDA data, as discussed earlier. In December 2007, these lenders accounted for 3.4 percent of home-purchase loans and 6.0 percent of refinance loans in HMDA; however, these loans were not proportionately distributed among the four loan types examined here. For the same period, these lenders represented less than 2 percent of FHA loans and 0.01 percent of VA loans. Their market share of GSE loans was 3.1 percent for homepurchase loans and 5.7 percent for refinance loans; for "other" loans, their share was 4.1 percent for home-purchase loans and 6.7 percent for refinance loans.

39. FHA-insured loans in the 2007 HMDA data for amounts that exceed the single-family loan limit can be attributed to recording errors in the data or to loans for two-, three-, or four-family structures, which have higher loan limits and are not identified separately in the HMDA data. 
13. Percent of home-purchase and refinance loans, by category of FHA and GSE eligibility, by type of loan and month of origination

Percent except as noted

\begin{tabular}{|c|c|c|c|c|c|c|c|c|c|c|c|c|c|c|}
\hline \multirow[b]{2}{*}{$\begin{array}{l}\text { Type of loan } \\
\text { by month } \\
\text { of origination }\end{array}$} & \multicolumn{7}{|c|}{ Home purchase } & \multicolumn{7}{|c|}{ Refinance } \\
\hline & $\begin{array}{c}\text { Number of } \\
\text { loans }\end{array}$ & Growth & $\begin{array}{c}\text { Market } \\
\text { share }\end{array}$ & $\begin{array}{c}\text { FHA } \\
\text { eligible, } \\
\text { no change }\end{array}$ & $\begin{array}{l}\text { Newly } \\
\text { FHA } \\
\text { eligible }\end{array}$ & \begin{tabular}{|c|} 
Newly \\
GSE and \\
FHA \\
eligible \\
\end{tabular} & $\begin{array}{c}\text { Other } \\
\text { eligibility } \\
\text { or no } \\
\text { change }^{1}\end{array}$ & $\begin{array}{c}\text { Number of } \\
\text { loans }\end{array}$ & Growth & $\begin{array}{c}\text { Market } \\
\text { share }\end{array}$ & $\begin{array}{c}\text { FHA } \\
\text { eligible, } \\
\text { no change }\end{array}$ & $\begin{array}{l}\text { Newly } \\
\text { FHA } \\
\text { eligible }\end{array}$ & \begin{tabular}{|c|} 
Newly \\
GSE and \\
FHA \\
eligible \\
\end{tabular} & \begin{tabular}{|c|} 
Other \\
eligibility \\
or no \\
change $^{1}$
\end{tabular} \\
\hline \multirow{2}{*}{\multicolumn{15}{|c|}{ FHA }} \\
\hline & & & & & & & & & & & & & & \\
\hline January & 21,857 & 100.0 & 14.1 & 96.0 & 3.1 & .2 & .7 & 25,634 & 100.0 & 9.9 & 93.9 & 5.0 & .3 & .9 \\
\hline February & 31,099 & 142.3 & 17.6 & 95.7 & 3.4 & .2 & .7 & 35,100 & 136.9 & 8.5 & 93.8 & 5.1 & .3 & 8 \\
\hline March .. & 43,193 & 197.6 & 20.9 & 94.1 & 4.8 & .3 & .7 & 38,896 & 151.7 & 10.1 & 92.2 & 6.5 & .4 & .9 \\
\hline April . & 56,654 & 259.2 & 25.7 & 90.3 & 7.5 & 1.1 & 1.0 & 43,173 & 168.4 & 12.4 & 85.7 & 12.0 & .9 & 1.4 \\
\hline May . & 70,554 & 322.8 & 28.5 & 88.1 & 9.1 & 1.6 & 1.3 & 39,700 & 154.9 & 15.5 & 83.6 & 13.4 & 1.3 & 1.7 \\
\hline June & 75,493 & 345.4 & 29.1 & $\begin{array}{l}8.1 \\
87.0\end{array}$ & 9.5 & 1.8 & 1.6 & 37,073 & 144.6 & 17.4 & $\begin{array}{l}03.0 \\
83.4\end{array}$ & 13.1 & 1.4 & 2.2 \\
\hline July ... & 79,949 & 365.8 & 31.4 & 87.1 & 9.4 & 1.9 & 1.6 & 35,697 & 139.3 & 21.4 & 83.5 & 12.8 & 1.4 & 2.2 \\
\hline August .... & 80,968 & 370.4 & 33.7 & 87.3 & 9.0 & 1.9 & 1.8 & 34,773 & 135.7 & 24.7 & 83.7 & 12.6 & 1.6 & 2.1 \\
\hline September & 90,597 & 414.5 & 40.5 & 88.2 & 8.4 & 1.8 & 1.7 & 37,068 & 144.6 & 26.6 & 83.5 & 12.8 & 1.6 & 2.2 \\
\hline October .. & 72,304 & 330.8 & 35.3 & 87.3 & 8.6 & 2.1 & 2.0 & 46,682 & 182.1 & 25.5 & 82.6 & 13.3 & 1.3 & 2.9 \\
\hline November & 54,914 & 251.2 & 36.5 & 88.0 & 8.2 & 1.9 & 1.9 & 33,774 & 131.8 & 28.8 & 83.0 & 13.2 & 1.2 & 2.7 \\
\hline December & 64,245 & 293.9 & 38.2 & 87.3 & $\begin{array}{l}.0 .2 \\
8.5\end{array}$ & 2.1 & 2.2 & 51,327 & 200.2 & 24.9 & 80.8 & 14.5 & 1.2 & 3.5 \\
\hline Total..... & 741,827 & & 29.6 & 88.7 & 8.1 & 1.6 & 1.6 & 458,897 & $\ldots$ & 16.2 & 85.4 & 11.5 & 1.1 & 2.0 \\
\hline \multicolumn{15}{|l|}{2007} \\
\hline Second half & 149,428 & . & 9.4 & 96.3 & 2.7 & .2 & .8 & 108,094 & $\ldots$ & 7.0 & 94.5 & 4.3 & .3 & 1.0 \\
\hline Total ....... & 257,674 & & 7.8 & 96.7 & 2.4 & .2 & .7 & 164,063 & & 4.6 & 94.9 & 3.9 & .3 & 1.0 \\
\hline \multirow{2}{*}{\multicolumn{15}{|c|}{ VA }} \\
\hline & & & & & & & & & & & & & & \\
\hline January .. & 6,976 & 100.0 & 4.5 & 77.2 & 17.4 & .6 & 4.8 & 2,625 & 100.0 & 1.0 & 74.7 & 17.9 & .3 & 7.2 \\
\hline February . & 8,747 & 125.4 & 5.0 & 76.7 & 17.4 & .6 & 5.3 & 5,026 & 191.5 & 1.2 & 70.7 & 21.8 & .2 & 7.2 \\
\hline March ... & 10,661 & 152.8 & 5.2 & 75.8 & 18.0 & 1.1 & 5.0 & 4,709 & 179.4 & 1.2 & 71.7 & 21.0 & .4 & 6.9 \\
\hline April.. & 11,710 & 167.9 & 5.3 & 75.1 & 17.9 & 1.4 & 5.7 & 4,437 & 169.0 & 1.3 & 74.8 & 18.2 & .4 & 6.7 \\
\hline May. & 13,651 & 195.7 & 5.5 & 73.6 & 18.5 & 1.3 & 6.5 & 3,441 & 131.1 & 1.3 & 77.5 & 16.4 & .6 & 5.5 \\
\hline June & $\begin{array}{l}14,707 \\
14,71\end{array}$ & 210.8 & 5.7 & 72.0 & 19.8 & 1.2 & 7.1 & 2,565 & 97.7 & 1.2 & 77.4 & $\begin{array}{l}16.4 \\
16.4\end{array}$ & .4 & 5.8 \\
\hline July..... & 14,948 & 214.3 & 5.9 & 73.0 & 18.8 & 1.3 & 6.9 & 2,071 & 78.9 & 1.2 & 80.6 & 14.1 & .6 & 4.7 \\
\hline August..... & 14,071 & 201.7 & 5.9 & 73.7 & 18.5 & 1.4 & 6.5 & 1,746 & 66.5 & 1.2 & 82.4 & 12.8 & .5 & 4.4 \\
\hline September. & 12,532 & 179.6 & 5.6 & 75.2 & 17.4 & 1.4 & 6.0 & 1,906 & 72.6 & 1.4 & 78.5 & 14.4 & .7 & 6.4 \\
\hline October.... & 13,202 & 189.2 & 6.4 & 76.0 & 16.2 & 1.5 & 6.3 & 3,111 & 118.5 & 1.7 & 73.9 & 18.1 & .9 & 7.2 \\
\hline Noven & 10,307 & 147.7 & 6.9 & 77.0 & 15.7 & 1.6 & 5.6 & 1,939 & 73.9 & 1.7 & 73.4 & 16.8 & 1.4 & 8.4 \\
\hline December.. & 12,131 & 173.9 & 7.2 & 76.2 & 15.4 & 1.8 & 6.7 & 4,953 & 188.7 & 2.4 & 67.5 & $\begin{array}{l}11.6 \\
21.6\end{array}$ & $\begin{array}{r}.4 \\
.9\end{array}$ & $\begin{array}{r}0.4 \\
10.0\end{array}$ \\
\hline \multirow{2}{*}{\multicolumn{15}{|c|}{2007}} \\
\hline & & & & & & & & & & & & & & \\
\hline Second half & 56,002 & & 3.5 & 75.8 & 18.8 & .1 & 5.3 & 8,129 & $\ldots$ & .5 & 79.6 & 15.3 & .2 & 4.8 \\
\hline Total........ & 106,710 & & 3.2 & 76.2 & 18.7 & .1 & 5.1 & 15,019 & $\ldots$ & .4 & 80.5 & 14.9 & .2 & 4.4 \\
\hline \multirow{2}{*}{\multicolumn{15}{|c|}{$\mathrm{GSE}^{2}$}} \\
\hline 2008 & & & & & & & & & & & & & & \\
\hline January . & 59,029 & 100.0 & 38.0 & 72.1 & 19.9 & .6 & 7.4 & 105,505 & 100.0 & 40.9 & 74.3 & 18.6 & .2 & 6.9 \\
\hline February. & 63,165 & 107.0 & 35.8 & 71.9 & 20.1 & .5 & 7.5 & 177,617 & 168.3 & 43.0 & 71.9 & 20.1 & .2 & 7.8 \\
\hline Marc & 70,510 & 119.4 & 34.1 & 70.9 & 20.9 & .4 & 7.8 & 157,348 & 149.1 & 40.9 & 74 & 18.0 & .2 & 6.8 \\
\hline April. & 68,462 & 116.0 & 31.1 & 70.6 & 20.8 & .6 & 8.0 & 132,992 & 126.1 & 38.1 & 76 & 16.9 & .2 & 6.5 \\
\hline May. & 71,840 & 121.7 & 29.0 & 69.4 & 20.6 & 1.2 & $\begin{array}{l}0.0 \\
8.8\end{array}$ & 86,447 & 81.9 & 33.9 & 76.7 & 16.3 & .5 & 6.6 \\
\hline June & $\begin{array}{l}11,040 \\
72,736\end{array}$ & 123.2 & 28.1 & $\begin{array}{l}68.0 \\
68.0\end{array}$ & 20.1 & 2.4 & $\begin{array}{l}.0 \\
9.5\end{array}$ & $\begin{array}{l}80,441 \\
69,358\end{array}$ & 65.7 & 32.6 & 74 & $\begin{array}{l}15.3 \\
15.8\end{array}$ & 2.7 & $\begin{array}{l}6.0 \\
6.8\end{array}$ \\
\hline $\mathrm{Ju}$ & 67,790 & 114.8 & 26.6 & 68 & 19.2 & 3.3 & 9.2 & 47,377 & 44.9 & 28.4 & 76 & 14.3 & 2.5 & 6.4 \\
\hline & 61,150 & $\begin{array}{l}103.6 \\
10.6\end{array}$ & 25.4 & 68 & 18.6 & 3.7 & 9.3 & 37,482 & 35.5 & 26.6 & 77 & 13.7 & 2.2 & 6.7 \\
\hline September. . & 50,053 & 84.8 & 22.4 & 70.4 & 17.3 & 3.8 & 8.4 & 38,002 & 36.0 & 27.3 & 76.0 & 14.5 & 2.4 & 7.1 \\
\hline October.... & 48,782 & 82.6 & 23.8 & 71.0 & 16.3 & 4.2 & 8.4 & 54,018 & 51.2 & 29.5 & 71.4 & 16.6 & 3.9 & 8.2 \\
\hline November.. & 34,849 & $\begin{array}{l}0.0 \\
59.0\end{array}$ & 23.2 & 71.2 & 16.7 & 3.9 & $\begin{array}{l}. .4 \\
8.3\end{array}$ & 31,474 & 29.8 & 26.8 & $\begin{array}{l}1.4 \\
75.1\end{array}$ & 14.8 & 2.6 & $\begin{array}{l}0.2 \\
7.5\end{array}$ \\
\hline December.. & $\begin{array}{l}54,049 \\
36,962\end{array}$ & 62.6 & 22.0 & 70.3 & 17.1 & 3.8 & $\begin{array}{l}.3 \\
8.9\end{array}$ & $\begin{array}{l}50,730 \\
60\end{array}$ & 57.6 & 29.5 & 68.2 & $\begin{array}{l}19.8 \\
19.8\end{array}$ & $\begin{array}{l}. .0 \\
2.3\end{array}$ & 9.7 \\
\hline \multirow{2}{*}{\multicolumn{15}{|c|}{2007}} \\
\hline & & & & & & & & & & & & & & \\
\hline Second half & 539,637 & . & 32.5 & 75.4 & 17.8 & .3 & 6.4 & 449,999 & $\ldots$ & 25.2 & 78.3 & 16.1 & .3 & 5.3 \\
\hline Total....... & $1,109,069$ & & 32.6 & 77.1 & 16.7 & .3 & 6.0 & 995,889 & & 26.2 & 79.4 & 15.1 & .3 & 5.1 \\
\hline
\end{tabular}

assuming that the share of FHA lending in each of these categories would have remained at its 2007 level in the absence of limit changes (derived from table). This same assumption would imply that FHA refinance lending was 8.9 percent higher because of the limit changes.

In contrast to the patterns for FHA lending, the proportion of VA loans in the four categories changed little over the course of the year, suggesting that the limit increases had little effect on VA lending. GSE lending showed only a modest boost from the limit increases (category 3). Under the same assumption used above, we estimate that GSE home-purchase lending would have been 1.9 percent lower and GSE refinance lending only 0.8 percent lower in 2008 had the GSE limits not been changed.

In sum, the effect of the limit increases on FHA, VA, and GSE lending appears to have been modest; the vast majority of the overall growth in both FHA and VA lending was in the categories in which there was no change in the eligibility standards. 
13. Percent of home-purchase and refinance loans, by category of FHA and GSE eligibility, by type of loan and month of origination-Continued

Percent except as noted

\begin{tabular}{|c|c|c|c|c|c|c|c|c|c|c|c|c|c|c|}
\hline \multirow[b]{2}{*}{$\begin{array}{l}\text { Type of loan } \\
\text { by month } \\
\text { of origination }\end{array}$} & \multicolumn{7}{|c|}{ Home purchase } & \multicolumn{7}{|c|}{ Refinance } \\
\hline & $\begin{array}{c}\text { Number of } \\
\text { loans }\end{array}$ & Growth & $\begin{array}{c}\text { Market } \\
\text { share }\end{array}$ & $\begin{array}{c}\text { FHA } \\
\text { eligible, no } \\
\text { change }\end{array}$ & $\begin{array}{c}\text { Newly } \\
\text { FHA } \\
\text { eligible }\end{array}$ & \begin{tabular}{|c|} 
Newly \\
GSE and \\
FHA \\
eligible \\
\end{tabular} & $\begin{array}{c}\text { Other } \\
\text { eligibility } \\
\text { or no } \\
\text { change }^{1}\end{array}$ & $\begin{array}{c}\text { Number of } \\
\text { loans }\end{array}$ & Growth & $\begin{array}{c}\text { Market } \\
\text { share }\end{array}$ & $\begin{array}{c}\text { FHA } \\
\text { eligible, no } \\
\text { change }\end{array}$ & $\begin{array}{l}\text { Newly } \\
\text { FHA } \\
\text { eligible }\end{array}$ & \begin{tabular}{|c|} 
Newly \\
GSE and \\
FHA \\
eligible \\
\end{tabular} & $\begin{array}{c}\text { Other } \\
\text { eligibility } \\
\text { or no } \\
\text { change }^{1}\end{array}$ \\
\hline \multicolumn{15}{|l|}{$\begin{array}{c}\text { Other }^{3} \\
2008\end{array}$} \\
\hline January . & 67,503 & 100.0 & 43.4 & 67.8 & 14.3 & 3.9 & 13.9 & 124,272 & 100.0 & 48.2 & 72.5 & 13.9 & 2.8 & 7.2 \\
\hline February & 73,628 & 109.1 & 41.7 & 68.4 & 14.7 & 3.3 & 13.7 & 195,520 & 157.3 & 47.3 & 71.0 & 15.7 & 2.1 & 10.7 \\
\hline March .. & 82,163 & 121.7 & 39.8 & 67.7 & 14.9 & 3.3 & 14.1 & 183,400 & 147.6 & 47.7 & 72.4 & 13.9 & 2.3 & 11.2 \\
\hline April.. & 83,434 & 123.6 & 37.9 & 68.2 & 14.5 & 3.4 & 13.9 & 168,781 & 135.8 & 48.3 & 74.1 & 13.2 & 2.0 & 11.4 \\
\hline May .. & 91,289 & 135.2 & 36.9 & 67.9 & 14.7 & 3.2 & 14.2 & 125,791 & 101.2 & 49.3 & 75.1 & 12.3 & 2.2 & 10.7 \\
\hline June . & 96,353 & 142.7 & 37.2 & 66.4 & 15.2 & 3.3 & 15.2 & 103,786 & 83.5 & 48.8 & 75.3 & 11.6 & 2.7 & 10.4 \\
\hline July.... & 91,786 & 136.0 & 36.1 & 67.5 & 14.5 & 3.5 & 14.5 & 81,715 & 65.8 & 49.0 & 76.3 & 10.6 & 2.7 & 10.4 \\
\hline August.. & 84,186 & 124.7 & 35.0 & 68.1 & 13.9 & 3.6 & 14.3 & 66,685 & 53.7 & 47.4 & 78.1 & 9.8 & 2.6 & 10.4 \\
\hline September. & 70,329 & 104.2 & 31.5 & 70.1 & 13.4 & 3.4 & 13.1 & 62,133 & 50.0 & 44.7 & 77.2 & 10.6 & 2.6 & 9.6 \\
\hline October.... & 70,623 & 104.6 & 34.5 & 70.8 & 13.3 & 3.2 & 12.7 & 79,514 & 64.0 & 43.4 & 74.0 & 13.2 & 2.9 & 9.6 \\
\hline November. . & 50,385 & 74.7 & 33.5 & 71.5 & 12.6 & 3.3 & 12.6 & 50,156 & 40.4 & 42.7 & 75.9 & 11.0 & 2.9 & 9.8 \\
\hline December. & 54,709 & 81.1 & 32.6 & 71.0 & 12.8 & 3.2 & 13.0 & 88,828 & 71.5 & 43.2 & 70.3 & 15.4 & 2.8 & 10.2 \\
\hline Total...... & 916,388 & $\ldots$ & 36.6 & 68.5 & 14.2 & 3.4 & 13.9 & $1,330,581$ & $\ldots$ & 47.1 & 73.8 & 13.1 & 2.4 & 11.5 \\
\hline 2007 & & & & & & & & & & & & & & \\
\hline Second half & 838,703 & $\ldots$ & 54.6 & 67.6 & 14.3 & 5.1 & 13.1 & 983,519 & . & 67.3 & 74.4 & 12.0 & 4.6 & 9.1 \\
\hline Total........ & $1,847,598$ & $\ldots$ & 56.4 & 67.5 & 13.2 & 6.3 & 13.0 & $2,396,004$ & $\ldots$ & 68.7 & 72.1 & 11.4 & 6.5 & 9.9 \\
\hline \multicolumn{15}{|l|}{$\begin{array}{l}\text { Total market } \\
2008\end{array}$} \\
\hline January . & 155,365 & 100.0 & 100 & 73.8 & 15.0 & 2.0 & 9.2 & 258,036 & 100.0 & 100 & 75.4 & 15.0 & 1.5 & 8.1 \\
\hline February & 176,639 & 113.7 & 100 & 74.9 & 14.8 & 1.6 & 8.8 & 413,263 & 160.2 & 100 & 73.3 & 16.7 & 1.1 & 8.8 \\
\hline March .. & 206,527 & 132.9 & 100 & 74.8 & 15.0 & 1.6 & 8.7 & 384,353 & 149.0 & 100 & 75.4 & 14.9 & 1.2 & 8.4 \\
\hline April... & 220,260 & 141.8 & 100 & 75.0 & 14.9 & 1.8 & 8.3 & 349,383 & 135.4 & 100 & 76.4 & 14.5 & 1.2 & 7.9 \\
\hline May .. & 247,334 & 159.2 & 100 & 74.4 & 15.0 & 2.0 & 8.5 & 255,379 & 99.0 & 100 & 77.0 & 13.9 & 1.5 & 7.7 \\
\hline June . . & 259,289 & 166.9 & 100 & 73.2 & 15.1 & 2.5 & 9.2 & 212,782 & 82.5 & 100 & 76.5 & 13.3 & 2.4 & 7.8 \\
\hline July..... & 254,473 & 163.8 & 100 & 74.2 & 14.4 & 2.8 & 8.6 & 166,860 & 64.7 & 100 & 78.1 & 12.2 & 2.3 & 7.4 \\
\hline August.... & 240,375 & 154.7 & 100 & 75.0 & 13.7 & 2.9 & 8.4 & 140,686 & 54.5 & 100 & 79.3 & 11.6 & 2.2 & 6.9 \\
\hline September. & 223,511 & 143.9 & 100 & 77.8 & 12.5 & 2.7 & 7.0 & 139,109 & 53.9 & 100 & 78.6 & 12.3 & 2.2 & 6.9 \\
\hline October.... & 204,911 & 131.9 & 100 & 77.0 & 12.5 & 3.0 & 7.5 & 183,325 & 71.0 & 100 & 75.4 & 14.3 & 2.8 & 7.5 \\
\hline November. . & 150,455 & 96.8 & 100 & 77.8 & 12.1 & 2.8 & 7.2 & 117,343 & 45.5 & 100 & 77.7 & 12.7 & 2.3 & 7.3 \\
\hline December. & 168,047 & 108.2 & 100 & 77.4 & 12.3 & 2.8 & 7.5 & 205,838 & 79.8 & 100 & 72.3 & 16.6 & 2.2 & 8.9 \\
\hline Total...... & $2,507,186$ & $\ldots$ & 100 & 75.3 & 14.0 & 2.4 & 8.3 & $2,826,357$ & $\cdots$ & 100 & 75.8 & 14.5 & 1.7 & 8.0 \\
\hline 2007 & & & & & & & & & & & & & & \\
\hline Second half & $1,583,770$ & $\ldots$ & 100 & 73.1 & 14.5 & 2.9 & 9.5 & $1,549,741$ & & 100 & 76.8 & 12.5 & 3.2 & 7.6 \\
\hline Total....... & $3,321,051$ & $\ldots$ & 100 & 73.2 & 13.7 & 3.6 & 9.5 & $3,570,975$ & & 100 & 75.1 & 12.0 & 4.6 & 8.3 \\
\hline
\end{tabular}

Note: First-lien mortgages for owner-occupied, 1-4 family, site-built properties; excludes business loans. Government-sponsored entity (GSE) and other loans have been adjusted for the fourth quarter of 2008; for more details, see text.

1. Includes loans that were not FHA or GSE eligible or were always GSE eligible.

2. GSE loans include all originations categorized as conventional and sold

\section{Pullback by PMI Companies and Its Implication for FHA and VA Lending}

With losses mounting in 2007 and 2008, PMI companies started raising prices and limiting coverage in some areas in the spring of 2008. These changes likely reduced the ability of the GSEs to purchase higher-LTV loans (loans with LTVs above 80 percent) because of the statutory requirement that such loans carry PMI (or a comparable credit enhancement) in order to be eligible for GSE purchase. The GSEs also raised their own underwriting fees for relatively high-LTV loans in March 2008 and further in June. 40

40. PMI annual premiums for loans with LTVs above 80 percent range from 0.50 percentage points to greater than 1.00 percentage point. On March 1, 2008, Fannie Mae and Freddie Mac raised their one-time delivery fees for 30 -year loans with LTVs above 70 percent to Fannie Mae, Freddie Mac, Ginnie Mae, or Farmer Mac by the end of the calendar year.

3. Other loans include loans originated with a Farm Service Agency or Rural Housing Service guarantee and conventional loans not sold to a government-related institution.

.. Not applicable.

Both the FHA and VA loan programs offer a form of credit insurance and, consequently, compete with the PMI companies. The two government programs likely increased their market share, at least to some extent, because the PMI and GSE price increases pushed the price of conventional higher-LTV loans above that for the FHA and VA programs for some

to a range of 0.75 to 2.00 percentage points, depending on the borrower's credit score. On March 9, 2008, both GSEs added a 0.25 percentage point additional fee for "market conditions." In June 2008 , the GSEs raised their fees again, by an average of 0.50 percentage points. In the summer of 2008, many PMI companies announced further increases in their rates, particularly in markets they defined as "distressed." In some areas, it became almost impossible to obtain PMI for loans with LTVs of greater than 90 percent. 
14. Disposition of home-purchase and refinance applications for private mortgage insurance, conventional loans, and nonconventional loans, by month of action taken, 2008

\begin{tabular}{|c|c|c|c|c|c|c|c|c|}
\hline \multirow{2}{*}{$\begin{array}{l}\text { Purpose of loan and month } \\
\text { of origination }\end{array}$} & \multicolumn{4}{|c|}{ Private mortgage insurance } & \multicolumn{4}{|c|}{ Conventional } \\
\hline & $\begin{array}{l}\text { Number of } \\
\text { applications }\end{array}$ & $\begin{array}{c}\text { Number of } \\
\text { loans covered }\end{array}$ & $\begin{array}{c}\text { Percent } \\
\text { withdrawn }\end{array}$ & Percent denied & $\begin{array}{l}\text { Number of } \\
\text { applications }\end{array}$ & $\begin{array}{c}\text { Number of } \\
\text { loans }\end{array}$ & $\begin{array}{c}\text { Percent } \\
\text { withdrawn }\end{array}$ & Percent denied \\
\hline \multicolumn{9}{|l|}{ Home purchase } \\
\hline January ....... & 102,859 & 73,644 & 3.2 & 3.0 & 217,027 & 124,433 & 14.2 & 21.2 \\
\hline February . & 89,047 & 59,372 & 3.9 & 4.2 & 217,777 & 134,085 & 13.0 & 19.4 \\
\hline March ... & 95,190 & 61,160 & 4.7 & 7.1 & 238,353 & 149,236 & 11.9 & 18.6 \\
\hline April. . & 96,396 & 65,874 & 4.2 & 4.8 & 239,885 & 147,684 & 13.2 & 19.7 \\
\hline May .. & 86,310 & 56,563 & 4.9 & 5.7 & 241,888 & 158,238 & 12.3 & 16.5 \\
\hline June . & 83,544 & 54,739 & 3.8 & 6.4 & 246,414 & 163,806 & 11.8 & 16.1 \\
\hline July... & 82,427 & 53,663 & 3.7 & 6.7 & 238,464 & 154,109 & 12.9 & 16.4 \\
\hline August.... & 71,505 & 45,766 & 4.5 & 6.2 & 213,776 & 139,688 & 12.8 & 16.3 \\
\hline September & 59,115 & 36,044 & 7.1 & 7.3 & 183,792 & 115,074 & 13.5 & 18.0 \\
\hline October.... & 69,844 & 32,936 & 12.6 & 7.6 & 183,889 & 113,280 & 14.3 & 18.4 \\
\hline November. . & 47,634 & 26,140 & 7.9 & 7.3 & 133,188 & 80,344 & 14.3 & 19.2 \\
\hline December.. & 44,118 & 24,680 & 6.3 & 8.4 & 138,183 & 86,176 & 14.0 & 17.6 \\
\hline \multicolumn{9}{|l|}{ Refinance } \\
\hline January & 53,565 & 37,895 & 3.3 & 3.1 & 562,486 & 229,794 & 16.7 & 40.6 \\
\hline February. & 56,450 & 39,379 & 5.6 & 3.9 & 721,408 & 373,119 & 15.4 & 30.3 \\
\hline March ... & 65,040 & 45,036 & 5.9 & 5.4 & 675,958 & 340,698 & 14.0 & 31.8 \\
\hline April. . & 56,452 & 36,362 & 6.5 & 5.6 & 632,885 & 301,741 & 14.6 & 34.2 \\
\hline May .. & 46,880 & 27,504 & 7.6 & 6.5 & 481,145 & 212,236 & 15.0 & 36.6 \\
\hline June . & 35,281 & 17,956 & 5.6 & 6.7 & 401,895 & 173,151 & 14.9 & 37.5 \\
\hline July....... & 31,766 & 13,779 & 6.8 & 7.5 & 344,968 & 129,109 & 16.6 & 43.0 \\
\hline August..... & 25,533 & 8,976 & 7.2 & 6.9 & 281,635 & 104,170 & 16.8 & 44.6 \\
\hline September . & 19,050 & 7,310 & 9.2 & 8.8 & 266,415 & 100,132 & 16.7 & 45.2 \\
\hline October.... & 30,028 & 8,841 & 17.7 & 7.1 & 311,590 & 133,495 & 15.9 & 41.0 \\
\hline November... & 17,166 & 6,464 & 12.4 & 7.5 & 216,267 & 81,625 & 18.4 & 44.6 \\
\hline December... & 16,166 & 7,187 & 11.8 & 15.9 & 332,578 & 149,506 & 21.2 & 34.6 \\
\hline
\end{tabular}

NotE: First-lien mortgages for owner-occupied, 1-4 family, site-built properties; excludes business loans.

borrowers. ${ }^{41}$ Consistent with this account, figure 5 indicates that the increase in FHA's home-purchase and refinance market shares accelerated just as GSE market shares began falling in early 2008. VA market shares, however, rose more steadily over time.

To further examine the potential link between PMI issuance and FHA and VA lending, we take advantage

41. For the first half of 2008 , the FHA charged a flat delivery fee of 1.50 percentage points and an annual premium of 0.50 percentage points to insure 30-year mortgages. On July 14, 2008, the FHA implemented a risk-based insurance system with upfront fees for 30 -year mortgages ranging from 1.25 to 2.25 percentage points and annual premiums from 0 to 0.55 percentage points, depending on the LTV and credit score of the borrower. The price changes were rolled back by the Congress, however, which passed legislation prohibiting the use of a risk-based pricing system after October 1, 2008. On that date, the FHA announced a new fee schedule with an upfront fee of 1.75 percentage points and an annual premium of 0.55 percentage points for 30-year loans with LTVs of 90 percent and higher and 0.50 percentage points for those with lower LTVs. During the period in which the FHA charged risk-based rates (and during the post-March fixed-rate period), FHA fees were lower than those of the GSEs with PMI for all borrowers except those with high credit scores.

The VA charged a 2.15 percentage point upfront fee and no annual premium for a veteran using the program for the first time with no down payment (the dominant choice); the fee was reduced to 1.50 percentage points with a 5 percent down payment and to 1.25 percentage points with a down payment of 10 percent or more. Fees were higher (at least 3.3 percentage points) for veterans using the program for a second or third time (there are also lifetime limits on coverage, which discourage or eliminate multiple usages). The VA has a streamlined refinance program that allows the refinancing of a VA loan into another VA loan with little documentation and a refinance fee of 0.50 percentage points (other refinance loans have the standard fees). VA statistics state that the average VA premium in 2008 was 2.13 percentage points. of the HMDA data filed by the PMI industry (appen$\operatorname{dix} B)$. These data reflect the disposition of applications for mortgage insurance received by the eight large PMI companies in 2008. These applications are arrayed by month, disposition, and loan type (table 14). For context, we also provide monthly information on application disposition for conventional (GSE, portfolio, and private) and nonconventional (FHA, VA, and Farm Service Agency or Rural Housing Service) lending.

The data on PMI denial and withdrawal rates reveal only mild evidence of a change in PMI companies' underwriting practices. Nevertheless, the sharp reduction in PMI issuance during 2008 (for instance, the ratio of PMI issuance to conventional homepurchase lending was almost 0.60 in January and fell to 0.27 in December) is consistent with the view that much of the high-LTV market shifted from the conventional market to the FHA and VA during 2008. In fact, on a county-by-county basis, we find a strong correlation between declines in PMI issuance and increases in FHA lending. ${ }^{42}$

42. Care must be exercised in comparing the PMI and loan data reported in HMDA. Only the largest PMI companies report HMDA data, but those that do report provide information on all their issuances, regardless of property location. HMDA loan reporting requirements favor urban areas, implying different underreporting patterns than the PMI data. Further, some PMI policies are written "after the fact" for loans that have already been originated, and as a result, the 
14. Disposition of home-purchase and refinance applications for private mortgage insurance, conventional loans, and nonconventional loans, by month of action taken, 2008-Continued

\begin{tabular}{|c|c|c|c|c|}
\hline \multirow{2}{*}{ Purpose of loan and month of origination } & \multicolumn{4}{|c|}{ Nonconventional } \\
\hline & Number of applications & Number of loans & Percent withdrawn & Percent denied \\
\hline \multicolumn{5}{|l|}{ Home purchase } \\
\hline January ....... & 48,005 & 31,019 & 12.4 & 21.0 \\
\hline February..... & 60,525 & 42,643 & 10.4 & 17.4 \\
\hline March ... & 82,971 & 57,397 & 11.1 & 18.1 \\
\hline April .. & 106,114 & 72,723 & 11.5 & 18.6 \\
\hline May... & 124,497 & 89,270 & 10.3 & 16.2 \\
\hline June .. & 135,951 & 95,696 & 10.7 & 16.9 \\
\hline July .... & 145,238 & 100,593 & 11.3 & 17.1 \\
\hline August.... & 145,820 & 100,914 & 11.5 & 16.6 \\
\hline September . & 156,340 & 108,708 & 11.4 & 16.2 \\
\hline October.... & 140,518 & 91,831 & 13.1 & 18.6 \\
\hline November. & 106,654 & 70,271 & 12.8 & 18.2 \\
\hline December.. & 119,790 & 82,030 & 12.0 & 16.2 \\
\hline \multicolumn{5}{|l|}{ Refinance } \\
\hline January .... & 58,180 & 28,355 & 15.0 & 36.4 \\
\hline February $\ldots \ldots \ldots \ldots \ldots$ & 72,641 & 40,302 & 15.3 & 29.1 \\
\hline March ......... & 85,825 & 43,779 & 17.0 & 32.5 \\
\hline April ... & 104,206 & 47,801 & 18.8 & 37.2 \\
\hline May ........ & 101,399 & 43,284 & 19.5 & 40.4 \\
\hline June ........ & 100,743 & 39,739 & 20.8 & 43.0 \\
\hline July ........ & 104,345 & 37,863 & 21.8 & 46.4 \\
\hline August....... & 101,003 & 36,617 & 22.5 & 46.2 \\
\hline September.. & 105,068 & 39,094 & 23.0 & 45.7 \\
\hline October...... & 126,943 & 49,935 & 22.2 & 43.5 \\
\hline November...$\ldots \ldots \ldots \ldots \ldots \ldots \ldots$ & 101,505 & 35,798 & 23.9 & 47.9 \\
\hline December.......................... & 130,673 & 56,460 & 22.8 & 38.9 \\
\hline
\end{tabular}

Data collected by LPS from the large mortgage servicers provide more direct evidence that high-LTV borrowers shifted to government-backed loans during 2008. These data show that the FHA share of firstlien, home-purchase loans with LTVs in excess of 80 percent rose sharply in 2008 from just over 20 percent to about 70 percent (figure 6). Similar to figure 5, the share of high-LTV loans sold to the GSEs began falling sharply just as the FHA's share began accelerating. The GSE share fell from more than 50 percent to 20 percent during 2008 .

The FHA share of loans with LTVs of 80 percent or below in the LPS data also increased yet remained at a low level, rising from 1 percent to almost 9 percent in 2008 (data not shown in figure). At the same time, the share of loans with LTVs of 80 percent or below that were sold to the GSEs held relatively constant throughout this period (after a brief increase early in 2007) at levels just over 80 percent. These patterns observed for home-purchase loans are also generally observed for refinance loans in the LPS data.

The VA share of high-LTV home-purchase loans grew modestly during most of 2007 and 2008, with a somewhat sharper increase at the end of 2008. By December 2008, this share exceeded 11 percent. Somewhat differently, the VA share of high-LTV

timing of the two data sources may not align perfectly. Nevertheless, the general relationship patterns between the two series should be informative. refinance loans peaked during the refinancing boom in early 2008. This share declined somewhat after that, but remained at higher levels than in 2007. For both home-purchase and refinance loans with LTVs of 80 percent or less, the VA market share was higher in 2008 than in 2007, but was consistently under 1 percent.

6. Share of LPS home-purchase lending with loan-to-value ratios greater than 80 percent, by type of loan, 2007-08

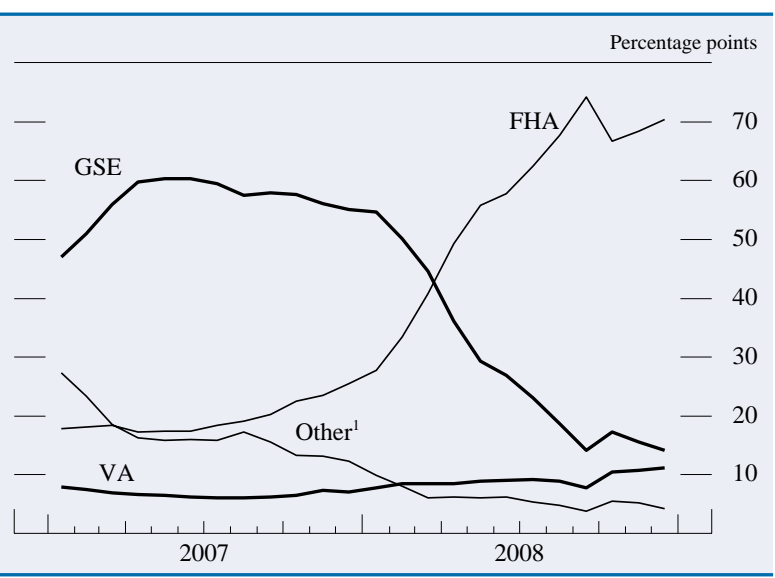

Note: The data are monthly. Loans are first liens. For more information about Lender Processing Services, Inc. (LPS), see text.

1. Other loans are Farm Service Agency or Rural Housing Service-guaranteed loans and conventional loans not sold to a GSE.

FHA Federal Housing Administration-insured.

GSE Government-sponsored entity-owned.

VA Department of Veterans Affairs-guaranteed.

Source: Lender Processing Services, Inc. 
15. Percent of home-purchase and refinance loans that are higher priced, by threshold and by type of loan and month of origination, 2008

Percent

\begin{tabular}{|c|c|c|c|c|c|c|c|c|}
\hline \multirow{2}{*}{$\begin{array}{l}\text { Type of loan by month } \\
\text { of origination }\end{array}$} & \multicolumn{4}{|c|}{ Home purchase } & \multicolumn{4}{|c|}{ Refinance } \\
\hline & Above HMDA & \begin{tabular}{|c|}
$\begin{array}{c}\text { Above PMMS } \\
+1.75^{1}\end{array}$ \\
\end{tabular} & \begin{tabular}{|c|}
$\begin{array}{c}\text { Above PMMS } \\
+2.75^{1}\end{array}$ \\
\end{tabular} & $\begin{array}{l}\text { High payment- } \\
\text { to-income ratio }\end{array}$ & Above HMDA & \begin{tabular}{|c|}
$\begin{array}{c}\text { Above PMMS } \\
+1.75^{1}\end{array}$ \\
\end{tabular} & $\begin{array}{l}\text { Above PMMS } \\
+2.75^{1}\end{array}$ & $\begin{array}{l}\begin{array}{l}\text { High payment- } \\
\text { to-income ratio }\end{array} \\
\end{array}$ \\
\hline \multicolumn{9}{|l|}{ FHA } \\
\hline 2008 & & & & & & & & \\
\hline January ... & 5.8 & 3.3 & .2 & 7.9 & 8.9 & 5.0 & .2 & 9.8 \\
\hline February. & 4.6 & 3.0 & .2 & 7.5 & 7.4 & 5.0 & .2 & 8.2 \\
\hline March ... & 4.0 & 1.7 & .2 & 9.0 & 7.1 & 3.5 & .3 & 10.5 \\
\hline April .. & 4.4 & 1.7 & .2 & 8.6 & 7.4 & 3.1 & .2 & 10.1 \\
\hline May.. & 3.8 & 1.3 & .2 & 9.4 & 7.2 & 2.6 & .3 & 10.8 \\
\hline June.. & 4.1 & 1.2 & .2 & 10.1 & 8.2 & 2.8 & .2 & 12.0 \\
\hline July ..... & 6.0 & 1.3 & .3 & 11.2 & 11.7 & 3.0 & .3 & 13.3 \\
\hline August .... & $\begin{array}{l}0.0 \\
15.7\end{array}$ & 1.3 & .3 & 13.1 & $\begin{array}{l}11.1 \\
23.9\end{array}$ & 2.5 & .2 & 16.0 \\
\hline September & 17.3 & 1.9 & .3 & 13.2 & 22.7 & 3.0 & .2 & 15.4 \\
\hline October.... & 20.7 & 2.8 & .3 & 13.7 & 22.1 & 3.4 & .2 & 15.6 \\
\hline November . & 23.2 & 3.1 & .3 & 13.8 & 25.9 & 3.9 & .2 & 16.1 \\
\hline December. . & 19.1 & 6.7 & 1.0 & 11.6 & 17.1 & 6.3 & .8 & 11.6 \\
\hline \multirow{2}{*}{\multicolumn{9}{|c|}{2007}} \\
\hline & & & & & & & & \\
\hline Second half. & 5.2 & 2.4 & .3 & 9.7 & 8.8 & 4.0 & .4 & 11.8 \\
\hline Total ....... & 4.3 & 2.1 & .3 & 9.4 & 7.2 & 3.4 & .5 & 11.2 \\
\hline \multirow{2}{*}{\multicolumn{9}{|c|}{ VA }} \\
\hline & & & & & & & & \\
\hline January.. & .4 & .2 & .0 & 15.9 & .6 & .3 & .1 & 3.5 \\
\hline February. & .3 & .2 & .0 & 14.2 & .0 & .1 & .0 & 3.0 \\
\hline March ... & .2 & .2 & .1 & 16.2 & .2 & .1 & .0 & 3.4 \\
\hline April ...... & .4 & .2 & .2 & 14.9 & .4 & .2 & .1 & 3.0 \\
\hline May........ & .3 & .2 & .2 & 14.9 & .4 & .1 & .0 & 2.9 \\
\hline June... & .3 & .1 & .1 & 16.3 & .3 & .1 & .0 & 3.6 \\
\hline July .... & .5 & .3 & .2 & 17.2 & .7 & .1 & .0 & 4.7 \\
\hline August & 1.0 & 2 & .1 & 17.8 & 1.2 & .2 & .1 & 5.3 \\
\hline September & 1.5 & .3 & .2 & $\begin{array}{l}17.0 \\
17.4\end{array}$ & 1.5 & .1 & .1 & 5.0 \\
\hline October.... & 2.6 & .3 & .2 & 16.4 & 1.0 & .2 & .1 & 4.0 \\
\hline November. & 3.6 & .2 & .2 & 15.2 & 1.1 & .1 & .0 & 4.8 \\
\hline December..... & 4.1 & 1.5 & .3 & 12.5 & 1.4 & .4 & .1 & 4.1 \\
\hline \multirow{2}{*}{\multicolumn{9}{|c|}{2007}} \\
\hline & & & & & & & & \\
\hline Second half... & .2 & .1 & .0 & 18.9 & .3 & .1 & .0 & 6.7 \\
\hline Total ....... & .2 & .1 & .1 & 17.9 & .3 & .1 & .1 & 6.6 \\
\hline \multicolumn{9}{|l|}{$\mathrm{GSE}^{2}$} \\
\hline 2008 & & & & & & & & \\
\hline January... & 8.2 & 6.1 & 1.2 & 13.7 & 3.5 & 2.7 & .5 & 13.8 \\
\hline February. & 7.2 & 5.3 & 1.0 & 12.3 & 1.9 & 1.5 & .3 & 10.5 \\
\hline March ... & 6.8 & 3.6 & .5 & 13.3 & 2.4 & 1.4 & .3 & 12.0 \\
\hline April .. & 5.2 & 2.4 & .2 & 12.5 & 2.7 & 1.5 & .3 & 11.7 \\
\hline May.. & 3.1 & 1.1 & .1 & 12.8 & 3.1 & 1.5 & .2 & 13.6 \\
\hline June.. & 2.3 & $\begin{array}{l}1.1 \\
.8\end{array}$ & .0 & 13.8 & 3.0 & 1.5 & .2 & 15.1 \\
\hline July .... & 2.3 & .5 & .0 & 14.7 & 2.8 & .8 & .1 & 16.6 \\
\hline August ... & 5.3 & .4 & .0 & 14.7 & 5.6 & .5 & .0 & 17.0 \\
\hline September & 5.1 & .5 & .0 & 14.4 & 5.7 & .5 & .0 & 15.8 \\
\hline October.... & 6.4 & .7 & .0 & $\begin{array}{l}14.4 \\
14.0\end{array}$ & 4.8 & .6 & .0 & 14.2 \\
\hline November . & 5.8 & .5 & .0 & 13.6 & 5.4 & .4 & .0 & 14.6 \\
\hline December. . & 4.1 & .8 & .0 & 12.2 & 2.1 & .3 & .0 & 10.4 \\
\hline \multirow{2}{*}{\multicolumn{9}{|c|}{2007}} \\
\hline & & & & & & & & \\
\hline Second half. & 10.0 & 7.2 & 2.5 & 15.8 & 6.6 & 4.8 & 1.3 & 18.2 \\
\hline Total ........ & 9.0 & 6.6 & 2.2 & 14.9 & 5.1 & 3.6 & .9 & 17.1 \\
\hline
\end{tabular}

\section{Evidence on the Quality of FHA and VA Loans}

The HMDA data contain only limited information indicative of the credit risk posed by borrowers. First, a payment-to-income (PTI) ratio can be estimated using reported income and loan size (if assumptions are made about interest rates on loans based on the date of loan origination). Second, loan pricing information reported in the HMDA data might also be used to infer risk.

We examine the monthly profiles of both of these risk measures by loan purpose and by the four loan product types (table 15). For each loan purpose and type, we show the proportion of loans that were reported in HMDA as higher priced, those with a PMMS spread (defined earlier) of at least 1.75 percentage points, and those with a PMMS spread greater than 2.75 percentage points (likely subprime loans). We also show the proportion of loans with estimated PTIs above 30 percent-the edge of an acceptable range in many loan underwriting programs.

Table 15 shows a striking increase in the incidence of HMDA-reported higher-priced FHA homepurchase and refinance lending. However, these increases seem to be driven largely by the widening gap between Treasury and mortgage market interest rates during 2008. When incidence was calculated 
15. Percent of home-purchase and refinance loans that are higher priced, by threshold and by type of loan and month of origination, 2008-Continued

Percent

\begin{tabular}{|c|c|c|c|c|c|c|c|c|}
\hline \multirow{2}{*}{$\begin{array}{l}\text { Type of loan by month } \\
\text { of origination }\end{array}$} & \multicolumn{4}{|c|}{ Home purchase } & \multicolumn{4}{|c|}{ Refinance } \\
\hline & Above HMDA & \begin{tabular}{|c|}
$\begin{array}{c}\text { Above PMMS } \\
+1.75^{1}\end{array}$ \\
\end{tabular} & \begin{tabular}{|l} 
Above PMMS \\
$+2.75^{1}$
\end{tabular} & $\begin{array}{l}\text { High payment- } \\
\text { to-income ratio }\end{array}$ & Above HMDA & \begin{tabular}{|c|}
$\begin{array}{c}\text { Above PMMS } \\
+1.75^{1}\end{array}$ \\
\end{tabular} & \begin{tabular}{|c|}
$\begin{array}{c}\text { Above PMMS } \\
+2.75^{1}\end{array}$ \\
\end{tabular} & $\begin{array}{l}\text { High payment- } \\
\text { to-income ratio }\end{array}$ \\
\hline \multicolumn{9}{|l|}{ Other ${ }^{3}$} \\
\hline \multicolumn{9}{|l|}{2008} \\
\hline January... & 12.0 & 9.6 & 3.7 & 15.6 & 19.7 & 17.8 & 11.3 & 16.1 \\
\hline February.. & 10.2 & 8.5 & 3.2 & 13.4 & 12.1 & 10.9 & 6.6 & 12.4 \\
\hline March ... & 9.5 & 6.9 & 3.1 & 14.7 & 13.3 & 10.8 & 6.7 & 13.9 \\
\hline April .. & 8.7 & 6.2 & 2.9 & 13.9 & 14.6 & 11.7 & 7.0 & 12.8 \\
\hline May.. & 7.1 & 4.9 & 2.3 & 13.8 & 15.5 & 11.8 & 7.3 & 13.2 \\
\hline June.. & 5.6 & 3.7 & 1.7 & 13.8 & 14.5 & 11.0 & 6.9 & 14.1 \\
\hline July . & 5.9 & 3.5 & 1.6 & 14.4 & 16.8 & 12.1 & 7.9 & 14.8 \\
\hline August ... & 8.9 & 3.6 & 1.6 & 14.7 & 22.7 & 13.7 & 9.2 & 14.5 \\
\hline September . & 9.2 & 4.2 & 2.0 & 14.5 & 24.5 & 16.5 & 10.8 & 14.6 \\
\hline October.... & 10.2 & 4.4 & 2.1 & 13.6 & 19.2 & 11.8 & 7.8 & 14.2 \\
\hline November & 10.7 & 4.6 & 2.5 & 13.6 & 22.2 & 14.2 & 9.7 & 14.5 \\
\hline December. . & 10.4 & 6.9 & 3.6 & 11.8 & 14.3 & 11.2 & 7.4 & 11.8 \\
\hline Total ...... & 8.8 & 5.4 & 2.5 & 14.0 & 16.1 & 12.4 & 7.8 & 13.7 \\
\hline \multicolumn{9}{|l|}{2007} \\
\hline Second half. & 12.7 & 9.7 & 4.5 & 18.1 & 23.1 & 19.7 & 12.0 & 20.7 \\
\hline Total ........ & 16.8 & 14.1 & 8.7 & 17.8 & 28.0 & 24.7 & 16.3 & 21.9 \\
\hline \multicolumn{9}{|l|}{ Total market } \\
\hline \multicolumn{9}{|l|}{2008} \\
\hline January... & 9.1 & 7.0 & 2.1 & 13.8 & 11.8 & 10.2 & 5.7 & 14.4 \\
\hline February.. & 7.7 & 6.0 & 1.7 & 12.0 & 7.2 & 6.3 & 3.3 & 11.1 \\
\hline March.... & 7.0 & 4.3 & 1.5 & 13.1 & 8.0 & 6.1 & 3.3 & 12.6 \\
\hline April .... & 6.1 & 3.5 & 1.2 & 12.1 & 9.0 & 6.6 & 3.5 & 11.9 \\
\hline May.......... & 4.6 & 2.5 & .9 & 12.3 & 9.8 & 6.7 & 3.7 & 12.8 \\
\hline June...... & 3.9 & 2.0 & .7 & 12.9 & 9.5 & 6.3 & 3.5 & 13.9 \\
\hline July ........ & 4.7 & 1.8 & .7 & 13.7 & 11.5 & 6.8 & 4.0 & 14.8 \\
\hline August ..... & 9.8 & 1.8 & .7 & 14.3 & 18.2 & 7.2 & 4.4 & 15.4 \\
\hline September... & 11.1 & 2.2 & .8 & 14.1 & 18.6 & 8.3 & 4.9 & 15.0 \\
\hline October........... & 12.5 & 2.7 & .9 & 13.9 & 15.4 & 6.2 & 3.4 & 14.4 \\
\hline November ......... & 13.6 & 2.8 & 1.0 & 13.8 & 18.4 & 7.3 & 4.2 & 14.8 \\
\hline December.......... & 11.9 & 5.1 & 1.6 & 11.9 & 11.1 & 6.5 & 3.4 & 11.1 \\
\hline Total $\ldots \ldots \ldots$ & 8.1 & 3.3 & 1.1 & 13.2 & 11.0 & 6.9 & 3.8 & 13.1 \\
\hline \multicolumn{9}{|l|}{2007} \\
\hline Second half.. & 10.7 & 7.8 & 3.3 & 16.6 & 17.8 & 14.7 & 8.5 & 19.4 \\
\hline Total ......... & 12.7 & 10.3 & 5.6 & 16.2 & 28.0 & 24.7 & 16.3 & 21.9 \\
\hline
\end{tabular}

NoTE: First-lien mortgages for owner-occupied, 1-4 family, site-built properties; excludes business loans. Government-sponsored entity (GSE) and other loans have been adjusted for the fourth quarter of 2008; for more details, see text. For explanation of Home Mortgage Disclosure Act (HMDA) pricereporting threshold, see text. The threshold and annual percentage rates (APRs) are for conventional first-lien 30-year prime mortgages.

1. PMMS is the prime APR from the Freddie Mac Primary Mortgage Market Survey; see notes to figure 1.

2. See note 2 , table 13 .

3. See note 3 , table 13 .

using the PMMS-adjusted spreads, which better reflect the true credit-risk premium, higher-priced lending rose far less dramatically. While the incidence of HMDA reported higher-priced FHA home-purchase loans more than doubled between 2007 and 2008 (4.3 percent versus 11.6 percent), the incidence of loans with a PMMS spread greater than 1.75 percentage points was small and nearly unchanged ( 2.1 percent versus 2.3 percent). Virtually none of the FHA or VA loans had PMMS spreads above 2.75 percentage points.

Nevertheless, both FHA and VA show a significant percentage of their loans with APRs in the range of prime plus 1.00 to 1.75 percentage points, which results in their being flagged as "higher priced" in HMDA; these loans are clearly not priced as prime loans. Much of the pricing can be attributed to FHA and VA insurance and guarantee fees. By our estimates, the average FHA loan in October and Novem- ber only had to be priced 0.25 percentage points above prime to be reported as higher priced in HMDA after insurance fees were factored into the APR ${ }^{43}$ VA loans only had to be priced 0.55 percentage points above prime to be reported as higher priced during this period.

Caution must be exercised in drawing too strong an inference about the quality of FHA and VA loans on the basis of a low incidence of PMMS-spread, higherpriced loans. The FHA (and to a lesser extent, the VA) cover most of the credit risk in a loan and, except for the brief period in the summer of 2008, charged flat rates. Consequently, pricing on FHA loans may not be particularly sensitive to the loan's credit risk. ${ }^{44}$

43. FHA fees added about 0.65 percentage points to an APR at the beginning of 2008 and rose slightly during the year.

44. Even though the FHA and VA cover most of the credit risk in a loan, they do not cover all of it. Lenders face recourse risk in the case 
Table 15 also shows an increase in the percentage of FHA borrowers with high PTI ratios for both home-purchase and refinance lending during 2008 as well as relative to 2007 , a potential sign of an increased risk profile for the FHA program. We note that this increase stems primarily from borrowers whose loans were newly eligible for FHA financing because of the limit increases. The incidence of high PTI ratios for borrowers that would have been eligible for FHA loans under 2007 limits rose only modestly (data not shown in tables).

LPS data provide more precise information on the credit quality of government-backed loans. In addition to LTV, these data provide borrower FICO scores, a commonly used credit score. Credit scores, such as FICO, provide a numeric ranking of the relative credit risk posed by a borrower and are a widely used measure of the credit risk of a loan. ${ }^{45}$

In 2007, the median FICO score of an FHA home-purchase loan in the LPS data at time of origination was approximately 625 , just above the range of credit scores often associated with subprime borrowers and about 100 points below the median FICO score for conventional loans in the LPS data (data not shown in tables). Similarly, the median LTV on 2007 FHA loans was 97.6 percent-more than 15 percentage points higher than the median for conventional loans in 2007. ${ }^{46}$

A comparison of the FICO scores of FHA borrowers in 2007 and 2008 suggests that the growth of FHA loans has predominantly involved loans to borrowers with higher credit scores. The median credit score rose to 664 in 2008. The share of FHA homepurchase loans to prime borrowers (those with scores greater than 660) grew from 30 percent in 2007 to more than 50 percent in 2008. In addition, the LPS data suggest that over 60 percent of the increase in FHA home-purchase activity between 2007 and 2008 was to borrowers with prime-quality FICO scores.

of fraud and servicing costs in the case of borrowers who do not make their payments. VA coverage may also be limited if the loan size is above the loan's coverage cap.

45. FICO scores are one summary measure of the credit risk posed by an individual based solely on the information contained in the credit reports maintained by the three national credit reporting agencies. FICO scores are produced using statistical models developed by Fair Isaac Corporation. A FICO score of 660 or more is often viewed as a score range associated with prime quality borrowers; a score under 620 is often associated with borrowers with subprime credit quality. For more information, see www.myfico.com/CreditEducation.

46. The LPS data tend to underrepresent the share of subprime loans; therefore, the median FICO score for conventional loans may be overstated. Also, LPS does not collect information on the combined LTV ratio of loans in its database. Because conventional loans may be more likely to involve junior liens, median LTVs for conventional loans will not accurately reflect the amount of borrower equity in the home.
The LPS data also indicate that FHA lending in 2008 continued to involve very low levels of borrower equity in the home. While the share of FHA home-purchase loans with LTVs exceeding 95 percent fell modestly from 72.3 percent in 2007 to 67.4 percent in 2008, the median LTV on these loans remained above 97 percent. Nevertheless, there is evidence that the credit scores of high-LTV borrowers improved as well. For example, while one-third of 2007 FHA home-purchase loans went to borrowers with LTVs in excess of 95 percent and FICO scores below 620, this share declined to 15 percent in 2008 . The numbers for FHA-insured refinancing are somewhat different, but they show a very similar trend toward borrowers with higher credit scores. Taken together, the FICO scores and LTVs reported in the LPS data for 2008 suggest that the growth of FHA loans has predominantly involved loans with lowerrisk characteristics than in 2007.

For VA loans, the LPS data indicate that 90 percent of VA first-lien, home-purchase loans had LTVs in excess of 95 percent in 2007, compared with 86 percent in 2008. Like FHA loans, while LTVs have remained high on VA loans, the credit scores of VA borrowers in the LPS data increased in 2008. The median credit score for first-lien, home-purchase VA borrowers was 672 in 2007 (within the range generally considered to be prime quality), and rose to 687 in 2008 .

It is important to keep in mind when interpreting the LPS data on FICO scores and LTVs that while these data suggest that the expansion of the FHA and VA programs has been primarily to borrowers with higher credit scores, the performance of these loans depends on many factors, including the future path of house prices and economic activity. Predicting how FHA and VA loans will perform is beyond the scope of this article.

\section{CHANGES IN TOTAL LENDING BY BORROWER AND AREA CHARACTERISTICS}

As highlighted in a previous article, the mortgage market experienced a severe contraction in lending from the beginning of 2006 to the end of 2007 related primarily to the collapse of the subprime mortgage market. ${ }^{47}$ As discussed above, 2008 was characterized by the increased role of FHA and VA as the overall mortgage market continued to decline. This section examines whether these changes had a differ-

47. See Avery, Brevoort, and Canner, "The 2007 HMDA Data." 
ential effect across borrower groups. As before, particular focus is paid to the effect of the surge in FHA and VA lending.

\section{Overall Changes from 2006 through 2008}

On the whole, lending for first-lien, site-built, owneroccupied home purchases reported in HMDA fell 22.3 percent from 2006 through 2007 and dropped an additional 24.5 percent from 2007 through 2008. Refinance lending fell 18.3 percent from 2006 through 2007, and 20.9 percent from 2007 through $2008 .{ }^{48}$ Although lending to all groups fell considerably during these years, some groups experienced steeper declines than others. Market shares for both black and Hispanic white borrowers fell from 2006 through 2007 and further declined in 2008, implying that lending to these groups fell more quickly than average between 2006 and 2008 (column 1, labeled "market share" in tables 16.A and 16.B). In contrast, the share of lending to Asian and non-Hispanic white borrowers rose.

Overall patterns for lower-income lending (borrowers with incomes below 80 percent of the median family income in their area or borrowers who live in census tracts with median family incomes in the year 2000 that were less than 80 percent of the median family income of their area) differ between homepurchase and refinance lending and between lowerincome borrowers and lower-income census tracts. The share of home-purchase loans made to lowerincome borrowers increased each year, while the share made to borrowers living in lower-income census tracts consistently fell. The share of refinance lending made to both lower-income groups decreased each year with the exception of a slight uptick of lending to lower-income borrowers in $2008 .{ }^{49}$

48. The decline in lending from 2006 to 2007 is likely to be overstated and the decline from 2007 to 2008 understated because of a serious reporting problem in the 2007 data. Federal Reserve tracking reports indicated that 169 lenders that reported HMDA data for 2006 and ceased operations sometime in 2007 or 2008 did not report HMDA data for 2007 (in an earlier section, we discuss the more limited problem of 15 nonreporting lenders in the 2008 HMDA data). Overall, these lenders accounted for about 8 percent of the site-built conventional first-lien loans in 2006. Since many of these lenders went out of business at or before the middle of 2007 , there is reason to believe that loan activity in the first half of 2007 is understated in the HMDA data (by up to 8 percent), though lending activity reported in HMDA in the second half of the year is likely to be more accurate. Since these lenders specialized in higher-priced subprime loans and disproportionately served blacks and Hispanic whites, the undercounts in the 2007 HMDA data were likely larger for these groups. For additional information, see Avery, Brevoort, and Canner, "The 2007 HMDA Data."

49. Monthly data suggest that the refinance boom in the beginning of 2008 may account for some of the overall decline in lower-income refinance lending for 2008 . The overall incidence of lower-income
Borrowers of different demographic groups showed large differences in their propensity to use different types of lenders with significant changes from year to year. All groups showed significant increases in their reliance on loans from banking institutions within their assessment areas. ${ }^{50}$ The substantial increase in market share by banks in their assessment areas (see bottom three rows) appears to have come from a decline in independent mortgage companies' market share between 2006 and 2007, and then a significant shift by banks from outside their assessment areas (where their past lending activity was more similar to that of independent mortgage companies) to lending within assessment areas between 2007 and 2008.

Borrowers of different demographic groups showed large differences in their propensity to use different types of loans, with significant changes from year to year. All groups showed significant increases in their use of FHA and VA programs from 2006 through 2008, especially black and Hispanic white borrowers. In 2008, more than 60 percent of home-purchase loans and almost 40 percent of refinance loans to black borrowers were government-backed. For Hispanic white borrowers, nearly 50 percent of homepurchase loans and 21 percent of refinance loans in 2008 were government-backed. ${ }^{51}$

In contrast, the share of loans sold to a nongovernment entity fell sharply, particularly so among loans to black and Hispanic white borrowers. About one-half of their home-purchase and refinance loans were sold in the nongovernment secondary market in

refinance lending fell from 31.7 percent in January to 27.2 percent in February and increased to 28.7 percent in March, suggesting that the refinance boom disproportionately involved higher-income borrowers. The damping of the incidence of lower-income refinance lending during this period was sufficiently large to explain much of the difference in the 2007-08 overall changes between home-purchase and refinance lending.

50. The Community Reinvestment Act (CRA) requires commercial banks and savings institutions to identify the geographic areas that they designate as their assessment areas, which are areas in which the institution has special responsibilities under the CRA. Typically, assessment areas correspond to the counties or markets in which the institution has banking branches. Each year, larger banking institutions file a list of the census tracts that compose their assessment areas. We use this list to determine whether a loan originated by a banking institution (or an affiliate) and reported in HMDA is within the institution's assessment area. For smaller institutions who do not supply a list, we approximate their assessment area by taking into account the counties in which they have banking offices.

51. One can derive from table 16 that there was a disproportionate increase in higher-income FHA lending. The expansion of FHA loan limits helps explain this disproportionate increase. For instance, only 8.6 percent of the FHA home-purchase loans originated in 2008 that would not have been eligible under 2007 loan limits were made to lower-income borrowers or tracts. In contrast, 48.0 percent of the 2008 FHA home-purchase loans that would have been eligible in earlier years were deemed lower income, numbers largely unchanged from 2007 (47.5 percent and 41.5 percent, respectively). 
16. Market share of home-purchase and refinance loans, by type of originator, type of loan, and loan pricing and by characteristic of borrower, of census tract, and of loan, 2006-08

A. Home purchase

Percent

\begin{tabular}{|c|c|c|c|c|c|c|c|c|c|c|c|c|}
\hline \multirow{3}{*}{$\begin{array}{l}\text { Characteristic of borrower, } \\
\text { of census tract, and of loan }\end{array}$} & \multirow{3}{*}{ Year } & \multirow{3}{*}{$\begin{array}{l}\text { Market } \\
\text { share }\end{array}$} & \multicolumn{4}{|c|}{ Originating institution } & \multicolumn{6}{|c|}{ Type of loan } \\
\hline & & & \multicolumn{2}{|c|}{$\begin{array}{l}\text { Depository (excluding } \\
\text { credit unions), by } \\
\text { property location }\end{array}$} & \multirow{2}{*}{$\begin{array}{l}\text { Credit } \\
\text { union }\end{array}$} & \multirow{2}{*}{$\begin{array}{l}\text { Independent } \\
\text { mortgage } \\
\text { company }\end{array}$} & \multirow[b]{2}{*}{ FHA } & \multirow[b]{2}{*}{ VA } & \multirow[b]{2}{*}{ RHS/FSA } & \multirow[b]{2}{*}{ GSE } & \multirow{2}{*}{$\begin{array}{c}\text { Sold to a } \\
\text { non- } \\
\text { government } \\
\text { entity }^{2}\end{array}$} & \multirow{2}{*}{$\begin{array}{l}\text { Held in } \\
\text { portfolio }\end{array}$} \\
\hline & & & $\begin{array}{c}\text { Within CRA } \\
\text { assessment } \\
\text { area }^{1}\end{array}$ & \begin{tabular}{|c} 
Outside CRA \\
assessment \\
area
\end{tabular} & & & & & & & & \\
\hline Minority status ${ }^{4}$ & & & & & & & & & & & & \\
\hline Black or African American ... & 2006 & 8.7 & 20.8 & 33.3 & 1.3 & 44.4 & 9.1 & 4.2 & .2 & 13.1 & 51.1 & 22.4 \\
\hline & 2007 & 7.6 & 32.4 & 36.4 & 2.0 & 29.1 & 15.0 & 6.0 & .6 & 25.9 & 20.8 & 31.6 \\
\hline & 2008 & 6.3 & 40.8 & 21.2 & 2.7 & 35.3 & 51.4 & 10.8 & 2.1 & 15.0 & 7.9 & 12.9 \\
\hline Hispanic white & 2006 & 12.1 & 23.8 & 32.0 & .9 & 43.2 & 5.6 & 1.4 & .3 & 13.8 & 52.4 & 26.5 \\
\hline & 2007 & 9.5 & 38.0 & 34.0 & 1.6 & 26.5 & 9.7 & 2.2 & .8 & 27.5 & 21.6 & 38.2 \\
\hline & 2008 & 8.5 & 47.0 & 16.2 & 2.2 & 34.6 & 44.7 & 4.5 & 2.3 & 22.9 & 9.1 & 16.5 \\
\hline Asian........... & 2006 & 4.5 & 31.8 & 32.3 & 1.4 & 34.4 & 1.5 & .5 & .0 & 26.4 & 41.4 & 30.2 \\
\hline & 2007 & 4.5 & 41.7 & 32.4 & 2.1 & 23.7 & 1.9 & .6 & .1 & 33.9 & 23.3 & 40.3 \\
\hline & 2008 & 4.9 & 55.7 & 17.2 & 3.2 & 24.0 & 11.9 & 1.3 & .2 & 46.2 & 17.4 & 23.0 \\
\hline Other minority ${ }^{5}$ & 2006 & 1.0 & 24.5 & 33.6 & 1.7 & 40.0 & 6.4 & 2.5 & .4 & 17.4 & 48.1 & 25.2 \\
\hline & 2007 & .9 & 37.5 & 35.4 & 2.8 & 24.5 & 10.1 & 3.6 & .8 & 27.9 & 22.2 & 35.4 \\
\hline & 2008 & .9 & 46.3 & 21.2 & 3.7 & 28.8 & 39.1 & 7.3 & 2.1 & 25.3 & 11.2 & 14.9 \\
\hline Non-Hispanic white & 2006 & 62.7 & 31.0 & 34.9 & 2.7 & 31.5 & 6.1 & 2.7 & .6 & 28.5 & 35.1 & 26.9 \\
\hline & 2007 & 66.8 & 36.5 & 36.3 & 3.5 & 23.7 & 7.3 & 3.1 & 1.0 & 34.3 & 23.9 & 30.4 \\
\hline & 2008 & 69.1 & 44.6 & 24.8 & 4.4 & 26.2 & 27.4 & 5.5 & 2.6 & 28.2 & 16.3 & 20.1 \\
\hline Missing ${ }^{6}$. & 2006 & 10.9 & 23.5 & 30.3 & 3.0 & 43.0 & 4.0 & 2.6 & .1 & 21.8 & 42.3 & 29.2 \\
\hline & 2007 & 10.6 & 33.2 & 34.7 & 3.7 & 28.3 & 6.0 & 3.6 & .3 & 31.5 & 23.4 & 35.1 \\
\hline & 2008 & 10.4 & 47.2 & 21.3 & 4.7 & 26.7 & 26.7 & 7.1 & .9 & 31.5 & 13.6 & 20.2 \\
\hline Borrower Income & & & & & & & & & & & & \\
\hline Lower .......... & 2006 & 23.5 & 31.6 & 32.7 & 2.8 & 33.0 & 11.4 & 2.4 & 1.0 & 25.7 & 34.1 & 25.4 \\
\hline & 2007 & 24.8 & 38.3 & 33.6 & 3.5 & 24.6 & 11.7 & 2.6 & 1.6 & 33.6 & 21.6 & 28.8 \\
\hline & 2008 & 28.1 & 44.3 & 22.9 & 3.9 & 28.9 & 37.6 & 4.3 & 4.2 & 23.4 & 14.0 & 16.5 \\
\hline Middle... & 2006 & 24.7 & 26.2 & 35.1 & 2.6 & 36.0 & 8.0 & 4.0 & .6 & 26.4 & 38.4 & 22.6 \\
\hline & 2007 & 25.2 & 33.3 & 36.4 & 3.5 & 26.7 & 10.8 & 4.8 & 1.2 & 33.7 & 22.2 & 27.4 \\
\hline & 2008 & 27.1 & 42.5 & 23.5 & 4.1 & 30.0 & 35.6 & 7.7 & 2.8 & 25.6 & 13.5 & 14.7 \\
\hline High. . & 2006 & 46.8 & 28.9 & 34.6 & 2.1 & 34.4 & 2.6 & 2.2 & .1 & 24.1 & 42.2 & 28.8 \\
\hline & 2007 & 47.0 & 37.2 & 36.6 & 2.9 & 23.3 & 4.4 & 2.9 & .3 & 32.2 & 24.2 & 36.1 \\
\hline & 2008 & 43.1 & 48.4 & 23.0 & 4.2 & 24.3 & 20.6 & 5.5 & .6 & 33.2 & 16.3 & 23.9 \\
\hline Missing ${ }^{6}$. & 2006 & 5.0 & 19.6 & 24.2 & 1.1 & 54.7 & 1.1 & .4 & .2 & 11.6 & 50.9 & 35.8 \\
\hline & 2007 & 3.1 & 29.0 & 33.1 & 2.2 & 35.8 & 3.3 & 9 & .5 & 21.7 & 33.2 & 40.4 \\
\hline & 2008 & 1.7 & 33.2 & 19.2 & 4.4 & 43.2 & 30.4 & 3.8 & 3.0 & 17.2 & 16.5 & 29.1 \\
\hline Census-tract income ${ }^{8}$ & & & & & & & & & & & & \\
\hline Lower ............ & 2006 & 15.7 & 25.6 & 33.0 & 1.7 & 39.6 & 7.6 & 1.7 & .3 & 18.3 & 46.0 & 26.2 \\
\hline & 2007 & 14.4 & 37.7 & 34.8 & 2.6 & 24.9 & 10.8 & 2.3 & .7 & 30.1 & 21.3 & 34.9 \\
\hline & 2008 & 13.1 & 46.8 & 20.6 & 3.4 & 29.2 & 39.2 & 4.5 & 1.9 & 24.4 & 11.8 & 18.2 \\
\hline Middle. & 2006 & 49.6 & 27.8 & 34.9 & 2.5 & 34.8 & 6.9 & 3.2 & .7 & 24.9 & 38.7 & 25.7 \\
\hline & 2007 & 49.7 & 35.0 & 37.1 & 3.4 & 24.5 & 9.0 & 3.9 & 1.2 & 33.0 & 22.4 & 30.4 \\
\hline & 2008 & 49.9 & 44.1 & 24.3 & 4.2 & 27.3 & 32.8 & 6.6 & 3.3 & 25.8 & 13.6 & 17.9 \\
\hline High. . . & 2006 & 33.8 & 31.4 & 33.0 & 2.2 & 33.5 & 3.7 & 2.2 & .2 & 27.0 & 38.5 & 28.5 \\
\hline & 2007 & 35.1 & 38.2 & 34.3 & 2.9 & 24.6 & 4.7 & 2.6 & .3 & 33.4 & 25.2 & 33.8 \\
\hline & 2008 & 35.9 & 48.0 & 22.1 & 3.9 & 26.0 & 21.6 & 5.0 & .8 & 33.1 & 17.6 & 21.8 \\
\hline Missing ${ }^{6}$. & 2006 & 1.0 & 2.1 & 15.2 & 9.6 & 72.3 & 3.8 & 2.2 & 1.2 & 11.2 & 43.5 & 38.1 \\
\hline & 2007 & .8 & 2.5 & 23.9 & 14.5 & 59.2 & 10.2 & 3.3 & 2.3 & 19.0 & 32.5 & 32.8 \\
\hline & 2008 & 1.1 & 2.3 & 24.4 & 12.3 & 61.1 & 33.4 & 3.9 & 5.1 & 15.0 & 18.7 & 23.9 \\
\hline Subprime indicators & & & & & & & & & & & & \\
\hline High PTI $^{9} \ldots . .$. & 2006 & 16.4 & 25.4 & 31.8 & 2.0 & 40.6 & 3.7 & 2.8 & .3 & 17.7 & 47.3 & 28.1 \\
\hline & 2007 & 16.2 & 35.1 & 34.6 & 2.9 & 27.4 & 4.5 & 3.6 & .6 & 30.0 & 25.9 & 35.5 \\
\hline & 2008 & 13.2 & 43.4 & 21.7 & 3.2 & 31.7 & 25.4 & 6.9 & 1.8 & 28.8 & 17.9 & 19.2 \\
\hline Piggyback & 2006 & 22.2 & 15.9 & 34.0 & .4 & 49.4 & .0 & .0 & .0 & 13.4 & 66.1 & 20.4 \\
\hline & 2007 & 10.8 & 33.3 & 38.5 & 1.0 & 27.4 & .0 & .0 & .0 & 33.0 & 33.6 & 33.4 \\
\hline & 2008 & 1.7 & 68.3 & 18.0 & 4.8 & 8.9 & .0 & .0 & .0 & 56.7 & 18.6 & 24.7 \\
\hline Total & 2006 & 100 & 28.4 & 33.8 & 2.3 & 35.5 & 5.9 & 2.6 & .4 & 24.4 & 39.8 & 26.8 \\
\hline & 2007 & 100 & 36.2 & 35.7 & 3.2 & 24.9 & 7.8 & 3.2 & .8 & 32.6 & 23.3 & 32.2 \\
\hline & 2008 & 100 & 45.4 & 23.0 & 4.1 & 27.5 & 29.6 & 5.7 & 2.2 & 28.1 & 14.9 & 19.4 \\
\hline
\end{tabular}

Note: First-lien mortgages for owner-occupied, 1-4 family, site-built properties; excludes business loans.

1. Includes lending by nondepository affiliates in the assessment areas of depository institutions covered by the Community Reinvestment Act of 1977 (CRA).

2. Includes loans sold into a private security, to another commercial bank, savings bank or savings association, or a life insurance company.

3. Freddie Mac Primary Mortgage Market Survey annual percentage rate (PMMS APR) is for a 30-year fixed-rate mortgage; for more details, see text.

4. Categories for race and ethnicity reflect revised standards established in 1997 by the Office of Management and Budget. Applicants are placed under only one category for race and ethnicity, generally according to the race and ethnicity of the person listed first on the application. However, under race, the application is designated joint if one applicant reported the single designation of white and the other reported one or more minority races. If the application is not joint but more than one race is reported, the following designations are made: If at least two minority races are reported, the application is designated as two or more minority races; if the first person listed on the application reports as two races, and one is white, the application is categorized under the minority race. For loans with two or more applicants, lenders covered under the Home Mortgage Disclosure Act report data on only two.

5. Other minority consists of American Indian or Alaskan Native, and $\mathrm{Na}-$ tive Hawaiian or other Pacific Islander.

6. Information for the characteristic was missing on the application

7. Borrower income is the total income relied upon by the lender in the loan underwriting. Income is expressed relative to the median family income of the metropolitan statistical area (MSA) or statewide non-MSA in which the property being purchased is located. "Lower" is less than 80 percent of the median; "middle" is 80 to 119 percent; and "high" is 120 percent or more.

8. The income category of a census tract is the median family income of the tract relative to that of the MSA or statewide non-MSA in which the tract is located. "Lower" is less than 80 percent of the median; "middle" is 20 to 119 percent; and "high" is 120 percent or more.

9. High payment-to-income ratio (PTI) is 30 percent or more.

FSA Farm Service Agency.

RHS Rural Housing Service. 
16. Market share of home-purchase and refinance loans, by type of originator, type of loan, and loan pricing and by characteristic of borrower, of census tract, and of loan, 2006-08

A. Home purchase-Continued

Percent

\begin{tabular}{|c|c|c|c|c|c|c|}
\hline \multirow{3}{*}{$\begin{array}{l}\text { Characteristic of borrower, } \\
\text { of census tract, and of loan }\end{array}$} & \multirow{3}{*}{ Year } & \multirow{3}{*}{ Market share } & \multicolumn{4}{|c|}{ Loan pricing } \\
\hline & & & \multirow{2}{*}{ Lower priced } & \multicolumn{3}{|c|}{ Higher priced, by percentage points above PMMS APR ${ }^{3}$} \\
\hline & & & & Less than 1.75 & $1.75-2.74$ & 2.75 or more \\
\hline \multicolumn{7}{|l|}{ Minority status ${ }^{4}$} \\
\hline \multirow[t]{3}{*}{ American ...... } & 2006 & 8.7 & 53.3 & 3.4 & 5.8 & 37.6 \\
\hline & 2007 & 7.6 & 72.3 & 3.9 & 8.4 & 15.3 \\
\hline & 2008 & 6.3 & 85.6 & 8.8 & 4.2 & 1.5 \\
\hline \multirow[t]{3}{*}{ Hispanic white....... } & 2006 & 12.1 & 57.6 & 4.6 & 6.8 & 31.0 \\
\hline & 2007 & 9.5 & 75.1 & 4.7 & 9.1 & 11.1 \\
\hline & 2008 & 8.5 & 84.8 & 9.3 & 4.2 & 1.6 \\
\hline \multirow[t]{3}{*}{ Asian .. } & 2006 & 4.5 & 83.6 & 2.5 & 2.9 & 11.0 \\
\hline & 2007 & 4.5 & 92.4 & 1.8 & 3.0 & 2.8 \\
\hline & 2008 & 4.9 & 96.0 & $\begin{array}{l}2.0 \\
2.6\end{array}$ & 1.0 & .4 \\
\hline \multirow[t]{3}{*}{ Other minority ${ }^{5}$. } & 2006 & 1.0 & 68.8 & 3.8 & 5.3 & 22.1 \\
\hline & 2007 & .9 & 83.4 & 3.3 & 6.0 & 7.3 \\
\hline & 2008 & .9 & 90.5 & 5.8 & 2.3 & 1.4 \\
\hline \multirow[t]{3}{*}{ Non-Hispanic white. } & 2006 & 62.7 & 83.9 & 2.4 & 3.3 & 10.4 \\
\hline & 2007 & 66.8 & 90.4 & 2.1 & 3.7 & 3.8 \\
\hline & 2008 & 69.1 & 92.8 & 4.2 & 1.9 & 1.1 \\
\hline \multirow[t]{3}{*}{ Missing ${ }^{6}$} & 2006 & 10.9 & 74.4 & 2.5 & 3.6 & 19.6 \\
\hline & 2007 & 10.6 & 87.6 & 2.2 & 4.1 & 6.1 \\
\hline \multirow{2}{*}{\multicolumn{7}{|c|}{ Borrower income ${ }^{7}$}} \\
\hline & & & & & & \\
\hline \multirow[t]{3}{*}{$\begin{array}{l}\text { Dorrower............ } \\
\quad \text { Lower.... }\end{array}$} & 2006 & 23.5 & 74.5 & 2.9 & 4.3 & 18.3 \\
\hline & 2007 & 24.8 & 85.0 & 3.1 & 5.6 & 6.3 \\
\hline & 2008 & 28.1 & 89.0 & 6.8 & 3.0 & 1.2 \\
\hline \multirow[t]{3}{*}{ Middle . } & 2006 & 24.7 & 75.6 & 2.4 & 3.5 & 18.6 \\
\hline & 2007 & 25.2 & 87.4 & 2.4 & 4.2 & 6.0 \\
\hline & 2008 & 27.1 & 92.1 & 5.0 & 2.0 & .9 \\
\hline High ........... & 2006 & 46.8 & 79.0 & 2.3 & 3.2 & 15.5 \\
\hline & 2007 & 47.0 & 89.3 & 1.9 & 3.6 & 5.1 \\
\hline & 2008 & 43.1 & 93.7 & 3.5 & 1.7 & 1.1 \\
\hline Missing $^{6}$ & 2006 & 5.0 & 74.4 & 8.9 & 11.4 & 5.3 \\
\hline & 2007 & 3.1 & 74.0 & 6.2 & 14.5 & 5.3 \\
\hline & 2008 & 1.7 & 91.7 & 3.7 & 2.2 & 2.5 \\
\hline Census-tract income ${ }^{8}$ & & & & & & \\
\hline Lower............. & 2006 & 15.7 & 62.5 & 3.7 & 5.5 & 28.3 \\
\hline & 2007 & 14.4 & 79.1 & 3.7 & 7.3 & 9.9 \\
\hline & 2008 & 13.1 & 87.0 & 7.9 & 3.7 & 1.4 \\
\hline Middle & 2006 & 49.6 & 75.8 & 3.0 & 4.2 & 17.1 \\
\hline & 2007 & 49.7 & 86.4 & 2.7 & 5.0 & 5.9 \\
\hline & 2008 & 49.9 & 91.0 & 5.4 & 2.4 & 1.2 \\
\hline High . & 2006 & 33.8 & 84.7 & 2.1 & 2.8 & 10.3 \\
\hline & 2007 & 35.1 & 91.7 & 1.7 & 3.1 & 3.5 \\
\hline & 2008 & 35.9 & 94.8 & 3.1 & 1.3 & .8 \\
\hline Missing ${ }^{6}$ & 2006 & 1.0 & 90.2 & 2.2 & 3.4 & 4.2 \\
\hline & 2007 & .8 & 93.1 & 1.7 & 3.5 & 1.7 \\
\hline & 2008 & 1.1 & 92.4 & 4.1 & 1.8 & 1.7 \\
\hline Subprime indicators & & & & & & \\
\hline High TII $^{9} \ldots . . .$. & 2006 & 16.4 & 63.2 & 1.6 & 2.6 & 32.6 \\
\hline & 2007 & 16.2 & 82.4 & 2.4 & 4.7 & 10.6 \\
\hline & 2008 & 13.2 & 93.9 & 3.2 & 1.6 & 1.3 \\
\hline Piggyback ....... & 2006 & 22.2 & 55.3 & 3.4 & 4.8 & 36.5 \\
\hline & 2007 & 10.8 & 84.0 & 2.0 & 2.9 & 11.0 \\
\hline & 2008 & 1.7 & 97.0 & 1.5 & 1.1 & .4 \\
\hline Total. & 2006 & 100 & 76.9 & 2.8 & 3.9 & 16.4 \\
\hline & 2007 & 100 & 87.3 & 2.5 & 4.6 & 5.6 \\
\hline & 2008 & 100 & 91.9 & 4.9 & 2.2 & 1.1 \\
\hline
\end{tabular}

2006, compared to less than 10 percent in 2008. In 2007, the GSEs and portfolio lenders captured market share among virtually all demographic groups. In 2008, the GSEs and portfolio lenders gave way in the home purchase lending market to the FHA and VA; however, the GSEs continued increasing their share of refinance loans made to all demographic groups that year.

The share of borrowers with income missing from home purchase loan applications fell from 2006 through 2008, but rose slightly for refinance loans in 2008 from 2007. Almost 60 percent of these refinance loans were FHA- or VA-backed, indicative of "streamlined" refinance programs in both agencies for which income data are not used.

The incidence of higher-priced lending significantly declined among all groups from 2006 to 2008 (last three columns, tables 16.A and 16.B). In total, the share of home-purchase loans priced 1.75 percentage points over PMMS fell from 20.3 percent in 2006 
16. Market share of home-purchase and refinance loans, by type of originator, type of loan, and loan pricing and by characteristic of borrower, of census tract, and of loan, 2006-08

\section{B. Refinance}

Percent

\begin{tabular}{|c|c|c|c|c|c|c|c|c|c|c|c|c|}
\hline \multirow{3}{*}{$\begin{array}{l}\text { Characteristic of borrower, } \\
\text { of census tract, and of loan }\end{array}$} & \multirow{3}{*}{ Year } & \multirow{3}{*}{$\begin{array}{l}\text { Market } \\
\text { share }\end{array}$} & \multicolumn{4}{|c|}{ Originating institution } & \multicolumn{6}{|c|}{ Type of loan } \\
\hline & & & \multicolumn{2}{|c|}{$\begin{array}{l}\text { Depository (excluding } \\
\text { credit unions), by } \\
\text { property location }\end{array}$} & \multirow{2}{*}{$\begin{array}{l}\text { Credit } \\
\text { union }\end{array}$} & \multirow{2}{*}{$\begin{array}{l}\text { Independent } \\
\text { mortgage } \\
\text { company }\end{array}$} & \multirow{2}{*}{ FHA } & \multirow{2}{*}{ VA } & \multirow{2}{*}{ RHS/FSA } & \multirow{2}{*}{ GSE } & \multirow{2}{*}{$\begin{array}{c}\text { Sold to a } \\
\text { non- } \\
\text { government } \\
\text { entity }^{2}\end{array}$} & \multirow{2}{*}{$\begin{array}{l}\text { Held in } \\
\text { portfolio }\end{array}$} \\
\hline & & & $\begin{array}{c}\text { Within CRA } \\
\text { assessment }^{1} \\
\text { area }^{1}\end{array}$ & \begin{tabular}{|c|}
$\begin{array}{c}\text { Outside CRA } \\
\text { assessment } \\
\text { area }\end{array}$ \\
\end{tabular} & & & & & & & & \\
\hline \multirow{3}{*}{$\begin{array}{l}\text { Minority status } \\
\text { Black or African American ... }\end{array}$} & & & & & & & & & & & & \\
\hline & $\begin{array}{l}2006 \\
2007\end{array}$ & $\begin{array}{l}9.5 \\
8.3\end{array}$ & $\begin{array}{l}20.9 \\
27.9\end{array}$ & $\begin{array}{l}37.3 \\
44.2\end{array}$ & $\begin{array}{l}2.1 \\
3.2\end{array}$ & 39.5 & 3.7 & .7 & .0 & 12.5 & 48.9 & 34.3 \\
\hline & 2008 & 6.0 & 39.9 & 27.8 & 5.4 & 26.9 & 35.1 & 4.0 & .0 & 22.4 & $\begin{array}{r}2.1 \\
8.5\end{array}$ & $\begin{array}{l}4.0 \\
29.9\end{array}$ \\
\hline \multirow[t]{3}{*}{ Hispanic white } & 2006 & 10.5 & 29.4 & 28.7 & 1.6 & 40.2 & 1.8 & .1 & .0 & 14.7 & 49.2 & 34.2 \\
\hline & 2007 & 9.2 & 40.4 & 34.6 & 2.7 & 22.3 & 3.8 & .2 & .0 & 24.7 & 23.9 & 47.3 \\
\hline & 2008 & 5.7 & 52.9 & 19.0 & 5.7 & 22.5 & 19.5 & 1.2 & .0 & 36.3 & 11.8 & 31.2 \\
\hline Asian... & 2006 & 3.0 & 34.8 & 30.6 & 1.8 & 32.6 & .5 & .0 & .0 & 20.2 & 41.5 & 37.8 \\
\hline & 2007 & 3.1 & 42.3 & 33.8 & 2.8 & 21.0 & .9 & .1 & .0 & 26.8 & 22.8 & 49.5 \\
\hline & 2008 & 3.1 & 55.4 & 20.5 & 5.7 & 18.4 & 4.4 & .3 & .0 & 48.4 & 16.2 & 30.7 \\
\hline Other minority ${ }^{5}$ & 2006 & 1.2 & 29.0 & 32.3 & 2.3 & 36.4 & 2.0 & .2 & .0 & 16.5 & 44.8 & 36.4 \\
\hline & 2007 & 1.0 & 37.4 & 38.5 & 3.4 & 20.7 & 3.7 & .3 & .0 & 23.8 & 23.3 & 48.9 \\
\hline & 2008 & .7 & 47.9 & 25.2 & 6.6 & 20.2 & 16.0 & 1.5 & .0 & 35.2 & 13.1 & 34.2 \\
\hline Non-Hispanic white & 2006 & 61.3 & 29.5 & 35.2 & 3.7 & 31.8 & 2.3 & .3 & .0 & 22.4 & 38.2 & 36.8 \\
\hline & 2007 & 64.4 & 33.8 & 39.1 & 4.8 & 22.3 & 4.5 & .4 & .0 & 27.7 & 23.9 & 43.6 \\
\hline & 2008 & 72.5 & 44.7 & 27.1 & 7.4 & 20.7 & 14.7 & 1.2 & .0 & 35.3 & 16.9 & 31.8 \\
\hline Missing ${ }^{6}$. & 2006 & 14.5 & 21.4 & 32.7 & 3.0 & 42.6 & 1.6 & .3 & .0 & 17.4 & 49.4 & 31.3 \\
\hline & 2007 & 14.0 & 27.7 & 40.5 & 3.7 & 28.1 & 3.8 & .5 & .0 & 24.3 & 28.4 & 43.0 \\
\hline Borrower income 7 & 2008 & 12.0 & 45.2 & 25.2 & 7.1 & 22.6 & 17.5 & 1.7 & .0 & 37.8 & 14.4 & 28.6 \\
\hline $\begin{array}{l}\text { Dorrower ........... } \\
\text { Lower }\end{array}$ & 2006 & 24.6 & 27.1 & 34.9 & 3.8 & 34.2 & 2.8 & .1 & .0 & 20.5 & 40.7 & 35.9 \\
\hline 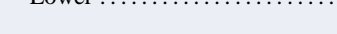 & 2007 & 23.3 & 32.0 & 40.0 & 4.8 & 23.2 & 5.6 & .2 & .0 & 26.5 & 22.9 & 44.8 \\
\hline & 2008 & 23.5 & 44.0 & 26.7 & 7.3 & 22.1 & 17.9 & .3 & .1 & 32.7 & 15 & 33.9 \\
\hline Middle. . & 2006 & 26.2 & 25.5 & 34.8 & 3.4 & 36.2 & 2.5 & .2 & .0 & 21.3 & 42.3 & 33.7 \\
\hline & 2007 & 25.6 & 30.7 & 40.2 & 4.6 & 24.6 & 6.0 & .2 & .0 & 27.7 & 24.0 & 42.2 \\
\hline & 2008 & 25.5 & 43.3 & 26.4 & 7.4 & 22.9 & 19.2 & .4 & .0 & 35.3 & 15.8 & 29.3 \\
\hline High. . & 2006 & 43.8 & 29.5 & 33.3 & 2.9 & 34.4 & 1.0 & .1 & .0 & 18.7 & 43.3 & 37.0 \\
\hline & 2007 & 46.2 & 35.8 & 38.0 & 4.0 & 22.2 & 2.5 & .1 & .0 & 25.6 & 25 & 46.2 \\
\hline & 2008 & 44.9 & 48.3 & 25.5 & 7.5 & 18.7 & 10.2 & .3 & .0 & 38.4 & 17 & 33.5 \\
\hline Missing ${ }^{6}$. & 2006 & 5.4 & 24.8 & 35.1 & 1.2 & 38.8 & 7.7 & 3.5 & .0 & 17.9 & 40.1 & 30.7 \\
\hline & 2007 & 5.0 & 31.2 & 40.9 & 1.7 & 26.5 & 11.7 & 5.5 & .0 & 23.1 & 23.2 & 36.5 \\
\hline Consus tract income 8 & 2008 & 6.2 & 37.0 & 29.3 & 2.1 & 31.7 & 41.7 & 17.0 & .0 & 23.3 & 5.0 & 13.0 \\
\hline $\begin{array}{l}\text { Censustract income } \\
\text { Lower .................. }\end{array}$ & 2006 & 17.9 & 24.9 & 33.1 & 2.4 & 39.3 & 2.6 & .2 & .0 & 15.2 & 47.2 & 34.7 \\
\hline & 2007 & 16.0 & 33.0 & 39.5 & 3.5 & 24.0 & 5.9 & .3 & .0 & 22.9 & 24.3 & 46.6 \\
\hline & 2008 & 11.9 & 44.8 & 25.6 & 6.4 & 23.3 & 23.4 & 1.2 & .0 & 30.5 & 12.5 & 32.3 \\
\hline Middle. . & 2006 & 52.0 & 26.9 & 35.2 & 3.3 & 34.6 & 2.5 & .4 & .0 & 20.6 & 41.1 & 35.5 \\
\hline & 2007 & 52.2 & 31.9 & 40.6 & 4.4 & 23.1 & 5.3 & .5 & .0 & 26.7 & 23 & 43.8 \\
\hline & 2008 & 52.0 & 43.7 & 27.6 & 7.3 & 21.4 & 18.6 & 1.6 & .0 & 33.9 & 14.9 & 31.0 \\
\hline High.. & 2006 & 29.5 & 31.1 & 33.2 & 3.0 & 32.8 & 1.4 & .2 & .0 & 21.4 & 40.8 & 36.2 \\
\hline Higni. & 2007 & 31.0 & 36.8 & 37.0 & 3.9 & 22.3 & 2.7 & .3 & .0 & 27.3 & 25.6 & 44.1 \\
\hline & 2008 & 35.1 & 49.2 & 24.5 & 6.5 & 19.8 & 10.2 & 1.1 & .0 & 39.5 & 18.1 & 31.1 \\
\hline Missing ${ }^{6}$. & 2006 & .6 & 2.7 & 21.1 & 17.8 & 57.2 & 1.6 & 1.0 & .1 & 10.3 & 57.7 & 29.4 \\
\hline & 2007 & .7 & 2.4 & 24.6 & 19.1 & 54.1 & 8.2 & .6 & .0 & 19.1 & 29.1 & 43.1 \\
\hline & 2008 & 1.0 & 2.2 & 24.9 & 22.3 & 50.9 & 22.1 & 1.6 & .1 & 20.5 & 19.7 & 36.0 \\
\hline $\begin{array}{l}\text { Subprime indicators } \\
\text { High PTI }^{9}\end{array}$ & & & & & & & & & & & & \\
\hline & $\begin{array}{l}2000 \\
2007\end{array}$ & 20.1 & $\begin{array}{l}28.3 \\
28.2\end{array}$ & 40.5 & $\begin{array}{l}1.0 \\
2.5\end{array}$ & $\begin{array}{l}44.8 \\
28.6\end{array}$ & 2.6 & .1 & .0 & 22.3 & $\begin{array}{l}50.2 \\
31.6\end{array}$ & 43.4 \\
\hline & 2008 & 13.1 & 39.5 & 27.3 & 4.5 & 28.6 & 15.5 & .4 & .0 & 34.8 & 20.3 & 29.0 \\
\hline Piggyback $^{10}$. & 2006 & $\ldots$ & 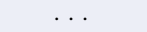 & & $\ldots$ & & $\ldots$ & & $\cdots$ & $\ldots$ & & $\ldots$ \\
\hline & $\begin{array}{l}2007 \\
2008\end{array}$ & $\ldots$ & $\ldots$ & $\cdots$ & $\cdots$ & $\cdots$ & $\cdots$ & & $\cdots$ & $\ldots$ & $\cdots$ & $\cdots$ \\
\hline Total... & 2006 & & 276 & & & 35.1 & 2.2 & .3 & & 19.8 & 42.2 & \\
\hline & 2007 & 100 & 33.4 & 39.2 & 4.2 & 23.2 & 4.6 & .4 & .0 & 26.2 & 24.4 & 44.3 \\
\hline & 2008 & 100 & 45.3 & 26.2 & 7.1 & 21.3 & 16.3 & 1.4 & .0 & 35.3 & 15.8 & 31.3 \\
\hline
\end{tabular}

Note: See notes to table 16.A

10. Piggyback data for refinance loans are omitted due to possibly significant underreporting of such loans.

... Not applicable.

to 10.2 percent in 2007 and further to 3.3 percent in 2008, reflecting the collapse of the subprime market. This trend was driven primarily by the striking decline in very high-priced lending (2.75 percentage points or more above PMMS). Black and Hispanic white borrowers and borrowers in lower-income tracts recorded the highest incidence of very high-priced home-purchase lending in 2006, and saw outsized declines in the incidence of these loans by 2008.

Other indicators of subprime lending also show declines from 2006 through 2008. For example, there was a reduction in the number of borrowers with PTIs above 30 percent and a virtual elimination of piggyback loans. In 2006, more than 22 percent of home- 
16. Market share of home-purchase and refinance loans, by type of originator, type of loan, and loan pricing and by characteristic of borrower, of census tract, and of loan, 2006-08

\section{B. Refinance-Continued}

Percent

\begin{tabular}{|c|c|c|c|c|c|c|}
\hline \multirow{3}{*}{$\begin{array}{l}\text { Characteristic of borrower, } \\
\text { of census tract, and of loan }\end{array}$} & \multirow{3}{*}{ Year } & \multirow{3}{*}{ Market share } & \multicolumn{4}{|c|}{ Loan pricing } \\
\hline & & & \multirow{2}{*}{ Lower priced } & \multicolumn{3}{|c|}{ Higher priced, by percentage points above $\mathrm{PMMS} \mathrm{APR}^{3}$} \\
\hline & & & & Less than 1.75 & $1.75-2.74$ & 2.75 or more \\
\hline \multicolumn{7}{|l|}{ Minority status ${ }^{4}$} \\
\hline \multirow[t]{3}{*}{ Black or African American } & 2006 & 9.5 & 49.4 & 4.2 & 9.5 & 37.0 \\
\hline & 2007 & 8.3 & 62.1 & 3.7 & 9.9 & 24.3 \\
\hline & 2008 & 6.0 & 77.1 & 7.4 & 5.6 & 9.9 \\
\hline \multirow[t]{3}{*}{ Hispanic white.. } & 2006 & 10.5 & 63.5 & 4.6 & 7.6 & 24.3 \\
\hline & 2007 & 9.2 & 74.1 & 4.2 & 8.5 & 13.3 \\
\hline & 2008 & 5.7 & 85.3 & 5.5 & 4.4 & 4.9 \\
\hline \multirow[t]{3}{*}{ Asian } & 2006 & 3.0 & 80.5 & 3.2 & 4.8 & 11.4 \\
\hline & 2007 & 3.1 & 87.6 & 2.4 & 5.4 & 4.6 \\
\hline & 2008 & 3.1 & 96.8 & 1.4 & 1.0 & .7 \\
\hline \multirow[t]{3}{*}{ Other minority ${ }^{5}$. } & 2006 & $\begin{array}{l}1.2 \\
1.2\end{array}$ & 67.4 & 4.0 & 7.4 & 21.2 \\
\hline & 2007 & 1.0 & 75.6 & 3.4 & 7.7 & 13.3 \\
\hline & 2008 & .7 & 84.5 & 4.3 & 3.9 & 7.3 \\
\hline \multirow[t]{3}{*}{ Non-Hispanic white.. } & 2006 & 61.3 & 75.0 & 3.2 & 6.1 & 15.7 \\
\hline & 2007 & 64.4 & 82.5 & 2.4 & 5.9 & 9.3 \\
\hline & 2008 & 72.5 & 89.8 & 3.8 & 2.9 & 3.6 \\
\hline \multirow[t]{3}{*}{ Missing $^{6}$} & 2006 & 14.5 & 63.2 & 3.6 & 7.7 & 25.6 \\
\hline & 2007 & 14.0 & 75.3 & 3.1 & 7.5 & 14.2 \\
\hline & 2008 & 12.0 & 90.3 & 4.4 & 3.1 & 2.3 \\
\hline \multirow{3}{*}{$\begin{array}{l}\text { Borrower income } \\
\text { Lower............ }\end{array}$} & 2006 & 24.6 & 624 & 36 & 79 & 261 \\
\hline & 2007 & $\begin{array}{l}23.0 \\
23.3\end{array}$ & $\begin{array}{l}6.4 \\
73.8\end{array}$ & $\begin{array}{l}3.6 \\
3.0\end{array}$ & $\begin{array}{l}7.9 \\
7.7\end{array}$ & $\begin{array}{l}26.1 \\
15.6\end{array}$ \\
\hline & 2008 & 23.5 & 82.9 & 5.9 & 4.7 & 6.5 \\
\hline \multirow[t]{3}{*}{ Middle . } & 2006 & 26.2 & 66.7 & 3.3 & 6.9 & 23.1 \\
\hline & 2007 & 25.6 & 77.3 & 2.8 & 6.6 & 13.3 \\
\hline & 2008 & 25.5 & 88.0 & 4.6 & 3.3 & 4.0 \\
\hline \multirow[t]{3}{*}{ High . } & 2006 & 43.8 & 74.2 & 3.3 & 6.0 & 16.6 \\
\hline & 2007 & 46.2 & 82.1 & 2.6 & 6.1 & 9.2 \\
\hline & 2008 & 44.9 & 91.8 & 3.1 & 2.4 & 2.7 \\
\hline Missing $^{6}$ & 2006 & 5.4 & 81.2 & 5.8 & 8.0 & 4.9 \\
\hline & 2007 & 5.0 & 84.7 & 3.7 & 7.7 & 3.9 \\
\hline & 2008 & 6.2 & 95.7 & 2.1 & 1.1 & 1.1 \\
\hline Census-tract income $e^{8}$ & & & & & & \\
\hline Lower............ & 2006 & 17.9 & 57.7 & 4.3 & 8.6 & 29.5 \\
\hline & 2007 & 16.0 & 69.1 & 3.7 & 9.0 & 18.1 \\
\hline & 2008 & 11.9 & 81.2 & 6.5 & 5.2 & 7.1 \\
\hline Middle .... & 2006 & 52.0 & 68.6 & 3.6 & 7.2 & 20.6 \\
\hline & 2007 & 52.2 & 77.9 & 2.9 & 7.0 & 12.2 \\
\hline & 2008 & 52.0 & 87.3 & 4.7 & 3.6 & 4.5 \\
\hline High .. & 2006 & 29.5 & 78.7 & 2.9 & 5.0 & 13.5 \\
\hline П1І & 2007 & 31.0 & 85.9 & 2.2 & 4.9 & 7.0 \\
\hline & 2008 & 35.1 & 94.1 & 2.4 & 1.8 & 1.7 \\
\hline Missing $^{6}$ & 2006 & .6 & 85.0 & 3.0 & 5.3 & 6.7 \\
\hline & 2007 & .7 & 90.3 & 1.8 & 4.6 & 3.3 \\
\hline & 2008 & 1.0 & 91.8 & 3.0 & 2.4 & 2.8 \\
\hline Subprime indicators & & & & & & \\
\hline${\text { High } \text { PTI }^{9} \ldots \ldots \ldots}^{9}$ & 2006 & 24.0 & 54.3 & 2.4 & 5.4 & 37.9 \\
\hline & 2007 & 20.1 & 70.6 & 2.3 & 6.3 & 20.7 \\
\hline & 2008 & 13.1 & 89.7 & 3.0 & 2.6 & 4.7 \\
\hline Piggyback $^{10}$. & 2006 & $\ldots$ & & $\ldots$ & $\ldots$ & $\ldots$ \\
\hline & 2007 & $\ldots$ & $\ldots$ & $\ldots$ & $\ldots$ & $\ldots$ \\
\hline & 2008 & $\cdots$ & $\ldots$ & $\cdots$ & $\cdots$ & $\cdots$ \\
\hline Total... & 2006 & 100 & 69.7 & 3.5 & 6.8 & 20.0 \\
\hline & 2007 & 100 & 79.1 & 2.8 & 6.7 & 11.5 \\
\hline & 2008 & 100 & 89.0 & 4.1 & 3.1 & 3.8 \\
\hline
\end{tabular}

purchase loans had piggyback loans. Two-thirds of these loans were sold into the private secondary market, and more than 36 percent were very high priced (PMMS spread of more than 2.75 percentage points). By 2008, virtually none of the piggyback loans that remained were higher priced, and most were sold to the GSEs.

\section{Borrower Incomes and Loan Sizes}

More detailed information on borrower incomes and loan sizes by year and loan type is shown in tables 17.A, 17.B, 18.A, and 18.B. The data show that the mean income for borrowers using FHA, VA, and "other" loans (almost all of which are conventional 
17. Cumulative distribution of home loans, by borrower income and by purpose, type, and pricing of loan, 2007-08

A. Home purchase

Percent

\begin{tabular}{|c|c|c|c|c|c|c|c|c|c|c|c|c|}
\hline \multirow{2}{*}{$\begin{array}{l}\text { Upper bound of } \\
\text { borrower income } \\
\text { (thousands of dollars) }^{1}\end{array}$} & \multicolumn{2}{|c|}{ FHA } & \multicolumn{2}{|c|}{ VA } & \multicolumn{2}{|c|}{ Other $^{2}$} & \multicolumn{2}{|c|}{ Total } & \multicolumn{2}{|c|}{ Higher priced } & \multicolumn{2}{|c|}{$\begin{array}{l}\text { Adjusted higher } \\
\text { priced }^{3}\end{array}$} \\
\hline & 2007 & 2008 & 2007 & 2008 & 2007 & 2008 & 2007 & 2008 & 2007 & 2008 & 2007 & 2008 \\
\hline 24 & 4.6 & 3.0 & .8 & .6 & 2.9 & 3.0 & 3.0 & 2.9 & 5.4 & 6.6 & 5.4 & 8.1 \\
\hline 49. & 43.5 & 35.7 & 28.2 & 24.1 & 26.2 & 25.1 & 27.6 & 28.2 & 35.6 & 42.2 & 35.2 & 42.8 \\
\hline 74 & 78.1 & 68.9 & 66.3 & 60.5 & 50.4 & 48.2 & 53.1 & 55.1 & 61.6 & 68.8 & 61.3 & 67.2 \\
\hline 99 . & 92.4 & 86.5 & 87.5 & 82.3 & 67.7 & 65.5 & 70.3 & 72.7 & 77.1 & $\begin{array}{l}82.9 \\
82.9\end{array}$ & 76.9 & 80.7 \\
\hline 124 & 96.9 & $\begin{array}{l}\text { o.J } \\
93.9\end{array}$ & $\begin{array}{l}85.7 \\
95.7\end{array}$ & $\begin{array}{l}8.5 \\
92.5\end{array}$ & $\begin{array}{l}0.1 \\
78.7\end{array}$ & $\begin{array}{l}76.9 \\
76.9\end{array}$ & 80.7 & 82.9 & 85.7 & $\begin{array}{l}8.9 \\
89.7\end{array}$ & 85.6 & 87.7 \\
\hline 149 . & 98.4 & 96.9 & 98.5 & 96.8 & 85.1 & 83.8 & 86.6 & 88.4 & 90.3 & 93.2 & 90.3 & 91.4 \\
\hline 199. & 99.3 & 99.0 & 99.8 & 99.3 & 92.0 & 91.2 & 92.9 & 94.0 & 95.0 & $\begin{array}{l}93.2 \\
96.3\end{array}$ & 95.1 & 95.1 \\
\hline 249 . & 99.6 & 99.6 & 99.9 & 99.8 & 95.1 & 94.5 & 95.6 & 96.3 & 97.0 & 97.6 & 97.1 & 96.7 \\
\hline $299 \ldots \ldots \ldots$ & 99.7 & 99.8 & 100.0 & 99.9 & 96.6 & 96.2 & 96.9 & 97.5 & 97.8 & 98.2 & 97.9 & 97.6 \\
\hline More than 299 & 100.0 & 100.0 & 100.0 & 100.0 & 100.0 & 100.0 & 100.0 & 100.0 & 100.0 & 100.0 & 100.0 & 100.0 \\
\hline $\begin{array}{l}\text { Meмо } \\
\text { Borrower income } \\
\text { by selected loan type } \\
\text { (thousands of dollars })^{1}\end{array}$ & & & & & & & & & & & & \\
\hline Mean ................. & 59.8 & 67.1 & 68.3 & 73.7 & 102.2 & 107.1 & 97.7 & 93.3 & 84.6 & 77.0 & 84.6 & 83.1 \\
\hline Median & 53.0 & 59.0 & 62.0 & 66.0 & 74.0 & 77.0 & 71.0 & 69.0 & 62.0 & 55.0 & 62.0 & 55.0 \\
\hline
\end{tabular}

NoTE: Includes only first-lien originations for owner-occupied, 1-4-family, site-built properties; excludes business-related loans. For loans with two or more applicants, lenders covered under the Home Mortgage Disclosure Act (HMDA) report data on only two. Income for two applicants is reported jointly. For definitions of lower- and higher-priced lending, see text.

1. Income amounts are reported under HMDA to the nearest $\$ 1,000$.
2. Other loans include loans originated with a Farm Service Agency or Rural Housing Service guarantee and conventional loans.

3. Adjusted higher-priced loans are those with annual percentage rates (APRs) 1.75 percentage points or more above the 30-year fixed-rate APR from the Freddie Mac Primary Mortgage Market Survey.

17. Cumulative distribution of home loans, by borrower income and by purpose, type, and pricing of loan, 2007-08

\section{B. Refinance \\ Percent}

\begin{tabular}{|c|c|c|c|c|c|c|c|c|c|c|c|c|}
\hline \multirow{2}{*}{$\begin{array}{c}\text { Upper bound of } \\
\text { borrower income } \\
\text { (thousands of dollars) }^{1}\end{array}$} & \multicolumn{2}{|c|}{ FHA } & \multicolumn{2}{|c|}{ VA } & \multicolumn{2}{|c|}{ Other $^{2}$} & \multicolumn{2}{|c|}{ Total } & \multicolumn{2}{|c|}{ Higher priced } & \multicolumn{2}{|c|}{$\begin{array}{l}\text { Adjusted higher } \\
\text { priced }^{3}\end{array}$} \\
\hline & 2007 & 2008 & 2007 & 2008 & 2007 & 2008 & 2007 & 2008 & 2007 & 2008 & 2007 & 2008 \\
\hline 24 . & 2.9 & 2.6 & 3.6 & 2.7 & 3.2 & 3.3 & 3.2 & 3.2 & 5.1 & 8.5 & 5.2 & 9.9 \\
\hline 49 . & 34.2 & 30.5 & 29.4 & 23.9 & 25.0 & 23.1 & 25.4 & 24.2 & 33.7 & 42.1 & 34.5 & 44.4 \\
\hline 74. & 72.2 & 65.9 & 65.9 & 57.3 & 51.2 & 47.7 & 52.1 & 50.4 & 62.1 & 70.5 & 63.2 & 71.7 \\
\hline 99 . & 91.1 & 86.3 & 86.4 & 80.1 & 69.9 & 66.5 & 70.8 & 69.5 & 79.1 & 85.5 & 80.0 & 86.0 \\
\hline 124. & 97.4 & 94.8 & 95.5 & 91.6 & 81.2 & 78.8 & 81.9 & 81.2 & 87.9 & 82.3 & 88.6 & 92.5 \\
\hline 149 . & 99.1 & 97.8 & 98.5 & 96.4 & 87.3 & 85.7 & 87.8 & 87.5 & 92.1 & 95.4 & 92.6 & 95.4 \\
\hline 199. & 96.7 & 99.5 & 99.6 & 99.2 & 93.5 & 92.8 & 93.7 & 93.8 & 96.1 & 97.7 & 96.4 & 97.7 \\
\hline 249 . & 99.8 & 99.8 & 99.9 & 99.7 & 96.0 & 95.7 & 96.2 & 96.3 & 97.7 & 98.6 & 97.9 & 98.6 \\
\hline 299. & 99.8 & 99.9 & 99.9 & 99.8 & 97.2 & 97.1 & 97.3 & 97.5 & 98.4 & 99.0 & 98.5 & 99.0 \\
\hline More than 299 & 100.0 & 100.0 & 100.0 & 100.0 & 100.0 & 100.0 & 100.0 & 100.0 & 100.0 & 100.0 & 100.0 & 100.0 \\
\hline $\begin{array}{l}\text { Mемо } \\
\text { Borrower income } \\
\text { by selected loan type } \\
\text { (thousands of dollars) }\end{array}$ & & & & & & & & & & & & \\
\hline Mean $\ldots \ldots \ldots \ldots \ldots \ldots$ & 64.2 & 68.3 & 67.7 & 75.3 & 96.8 & 101.7 & 95.3 & 96.7 & 80.3 & 69.1 & 78.7 & 67.5 \\
\hline Median ....... & 59.0 & 62.0 & 63.0 & 68.0 & 73.0 & 77.0 & 72.0 & 74.0 & 62.0 & 55.0 & 62.0 & 54.0 \\
\hline
\end{tabular}

NotE: See notes to table 17.A.

loans) increased for both home-purchase and refinance lending from 2007 through 2008. Though the income of FHA and VA borrowers rose relative to borrowers using other loans, FHA and VA borrowers continued to have relatively low income levels. Meanwhile, the incomes of borrowers with higher-priced loans, already lower than that of borrowers with lower-priced loans, fell relatively more in 2008.

Loan amounts also differed across loan types, with government-insured or guaranteed loans generally being smaller than conventional loans. In 2008, though, the upward shift in the distribution of loan amounts for both FHA-insured and VA-guaranteed loans contrasted with a downward shift in the distribution for other loans. Overall, average loan amounts for all loans fell for both home-purchase and refinance lending, but the drop was largest among higherpriced loans. 
18. Cumulative distribution of home loans, by loan amount and by type, 2007-08

A. Home purchase

Percent

\begin{tabular}{|c|c|c|c|c|c|c|c|c|c|c|c|c|}
\hline \multirow{2}{*}{$\begin{array}{c}\text { Upper bound of } \\
\text { loan amount } \\
\text { (thousands of dollars) }^{1}\end{array}$} & \multicolumn{2}{|c|}{ FHA } & \multicolumn{2}{|c|}{ VA } & \multicolumn{2}{|c|}{ Other $^{2}$} & \multicolumn{2}{|c|}{ Total } & \multicolumn{2}{|c|}{ Higher priced } & \multicolumn{2}{|c|}{$\begin{array}{l}\text { Adjusted higher } \\
\text { priced }^{3}\end{array}$} \\
\hline & 2007 & 2008 & 2007 & 2008 & 2007 & 2008 & 2007 & 2008 & 2007 & 2008 & 2007 & 2008 \\
\hline 24 & .1 & .1 & .0 & .0 & .4 & .5 & .3 & .3 & 1.0 & 2.0 & 1.1 & 3.9 \\
\hline 49 & 2.2 & 1.5 & .4 & .3 & 2.3 & 2.8 & 2.3 & 2.3 & 5.6 & 10.0 & 5.8 & 15.0 \\
\hline 74 & 11.4 & 7.9 & 2.5 & 2.2 & 7.8 & 8.4 & 7.9 & 7.9 & 15.9 & 23.6 & 16.3 & 29.6 \\
\hline 99. & 26.6 & 18.9 & 8.8 & 7.3 & 15.5 & 16.0 & 16.1 & 16.3 & 27.1 & 37.8 & 27.6 & 42.5 \\
\hline 149 & 60.6 & 47.6 & 32.9 & 28.7 & 35.9 & 35.6 & 37.7 & 38.7 & 48.1 & 61.8 & 48.7 & 63.3 \\
\hline 199. & 85.1 & 71.4 & 60.6 & 55.4 & 53.4 & 52.4 & 56.1 & 58.2 & 63.1 & 76.4 & 63.5 & 75.8 \\
\hline 274. & 96.3 & 89.1 & 85.0 & 80.2 & 71.4 & 70.6 & 73.8 & 76.6 & 77.7 & 87.1 & 78.0 & 86.1 \\
\hline 417. & 99.8 & 98.2 & 98.9 & 97.0 & 88.6 & 89.0 & 89.8 & 92.2 & 91.2 & 95.3 & 91.4 & 94.4 \\
\hline 625 & 100.0 & 99.7 & 100.0 & 99.8 & 96.1 & 96.5 & 96.5 & 97.6 & 97.5 & 98.4 & 97.7 & 98.0 \\
\hline $729 \ldots \ldots \ldots \ldots$ & 100.0 & 99.9 & 100.0 & 100.0 & 97.4 & 97.6 & 97.7 & 98.4 & 98.5 & 98.9 & 98.7 & 98.6 \\
\hline More than 799 & 100.0 & 100.0 & 100.0 & 100.0 & 100.0 & 100.0 & 100.0 & 100.0 & 100.0 & 100.0 & 100.0 & 100.0 \\
\hline $\begin{array}{l}\text { МЕмо } \\
\text { Loan amount } \\
\text { (thousands of dollars) }\end{array}$ & & & & & & & & & & & & \\
\hline Mean .............. & 142.3 & 171.3 & 193.1 & 207.3 & 241.1 & 238.4 & 231.9 & 216.8 & 205.5 & 164.5 & 202.6 & 164.6 \\
\hline Median & 134.0 & 154.0 & 179.0 & 188.0 & 188.0 & 190.0 & 180.0 & 176.0 & 155.0 & 124.0 & 152.0 & 116.0 \\
\hline
\end{tabular}

NoTE: Includes only first-lien originations for owner-occupied, 1-4 family, site-built properties; excludes business-related loans. For definitions of lowerand higher-priced lending, see text.

1. Loan amounts are reported under the Home Mortgage Disclosure Act to

the nearest $\$ 1,000$. [Text of column heading was revised on August 30, 2010 , to correct a printing error.-Ed.]

2. See note 2 , table 17.A.

8. Cumulative distribution of home loans, by loan amount and by type, 2007-08

B. Refinance

Percent

\begin{tabular}{|c|c|c|c|c|c|c|c|c|c|c|c|c|}
\hline \multirow{2}{*}{$\begin{array}{c}\text { Upper bound of } \\
\text { loan amount } \\
\text { (thousands of dollars) }^{1}\end{array}$} & \multicolumn{2}{|c|}{ FHA } & \multicolumn{2}{|c|}{ VA } & \multicolumn{2}{|c|}{ Other $^{2}$} & \multicolumn{2}{|c|}{ Total } & \multicolumn{2}{|c|}{ Higher priced } & \multicolumn{2}{|c|}{$\begin{array}{c}\text { Adjusted higher } \\
\text { priced }^{3}\end{array}$} \\
\hline & 2007 & 2008 & 2007 & 2008 & 2007 & 2008 & 2007 & 2008 & 2007 & 2008 & 2007 & 2008 \\
\hline 24 . & .1 & .0 & .1 & .0 & 1.1 & 1.1 & 1.0 & .9 & 2.2 & 5.3 & 2.3 & 7.1 \\
\hline 49 & 1.0 & .7 & .9 & .7 & 4.1 & 4.8 & 3.9 & 4.0 & 7.0 & 17.7 & 7.1 & 21.5 \\
\hline 74. & 6.1 & 4.7 & 4.7 & 4.0 & 10.5 & 11.7 & 10.3 & 10.5 & 16.0 & 33.1 & 16.3 & 37.7 \\
\hline 99 . & 17.3 & 13.5 & 13.5 & 10.9 & 18.5 & 20.2 & 18.4 & 19.0 & 26.2 & 46.8 & 26.8 & 51.1 \\
\hline 149. & 50.2 & 41.3 & 40.1 & 32.6 & 37.2 & 39.7 & 37.8 & 39.8 & 47.2 & 68.7 & 48.4 & 71.6 \\
\hline 199. & 76.5 & 66.7 & 64.5 & 56.1 & 53.7 & 56.4 & 54.8 & 58.1 & 63.2 & 81.8 & 64.4 & 83.5 \\
\hline 274 . & 93.4 & 88.1 & 87.5 & 81.1 & 71.4 & 74.2 & 72.5 & 76.5 & 78.2 & 91.1 & 79.3 & 91.8 \\
\hline 417 . & 99.7 & 98.7 & 99.3 & 98.1 & 88.9 & 92.0 & 89.4 & 93.1 & 91.5 & 97.2 & 92.1 & 97.3 \\
\hline 625 & 100.0 & 99.8 & 100.0 & 99.9 & 96.4 & 97.7 & 96.6 & 98.1 & 97.7 & 99.1 & 97.9 & 99.1 \\
\hline $729 \ldots \ldots \ldots$ & 100.0 & 100.0 & 100.0 & 100.0 & 97.7 & 98.4 & 97.8 & 98.7 & 98.6 & 99.4 & 98.8 & 99.4 \\
\hline More than 799 & 100.0 & 100.0 & 100.0 & 100.0 & 100.0 & 100.0 & 100.0 & 100.0 & 100.0 & 100.0 & 100.0 & 100.0 \\
\hline \multirow{2}{*}{\multicolumn{13}{|c|}{$\begin{array}{l}\text { МЕмо } \\
\text { Loan amount } \\
\text { (thousands of dollars) }\end{array}$}} \\
\hline & & & & & & & & & & & & \\
\hline Mean ................. & 160.3 & 179.6 & 181.7 & 200.2 & 235.0 & 217.2 & 231.4 & 210.8 & 202.3 & 138.0 & 197.0 & 130.6 \\
\hline Median ... & 149.0 & 164.0 & 168.0 & 186.0 & 186.0 & 178.0 & 183.0 & 175.0 & 157.0 & 105.0 & 153.0 & 97.0 \\
\hline
\end{tabular}

NotE: See notes to table 18.A.

\section{DIFFERENCES IN LENDING OUTCOMES BY RACE, ETHNICITY, AND SEX OF THE BORROWER}

Analyses of HMDA data from earlier years revealed substantial differences in the incidence of higherpriced lending and in denial rates across racial and ethnic lines; analyses further showed that such differences could not be fully explained by factors included in the HMDA data. ${ }^{52}$ Studies also found that differ-

52. See Avery, Brevoort, and Canner, "The 2006 HMDA Data"; Avery, Brevoort, and Canner, "Higher-Priced Home Lending and the 2005 HMDA Data"; and Avery, Canner, and Cook, "New Information Reported under HMDA." ences across groups in mean APR spreads paid by those with higher-priced loans were generally small..$^{53}$ Here we examine the 2008 HMDA data to determine the extent to which these differences persist, comparing results for 2008 with those for 2007.

Although the HMDA data include a variety of detailed information about mortgage transactions,

53. See, for example, Andrew Haughwout, Christopher Mayer, and Joseph Tracy (2009), Subprime Mortgage Pricing: The Impact of Race, Ethnicity, and Gender on the Cost of Borrowing, Staff Report no. 368 (New York: Federal Reserve Bank of New York, April); and Marsha Courchane (2007), "The Pricing of Home Mortgage Loans to Minority Borrowers: How Much of the APR Differential Can We Explain?" Journal of Real Estate Research, vol. 29 (4), pp. 400-39. 
many key factors that are considered by lenders in credit underwriting and pricing are not included. Accordingly, it is not possible to determine from HMDA data alone whether racial and ethnic pricing disparities reflect illegal discrimination. However, analysis using the HMDA data can account for some factors that are likely related to the lending process. Given that lenders offer a wide variety of loan products for which basic terms can differ substantially, the analysis here can only be viewed as suggestive.

Comparisons of average outcomes for each racial, ethnic, or gender group are made both before and after accounting for differences in the borrowerrelated factors contained in the HMDA data (income, loan amount, location of the property or MSA, and presence of a co-applicant) and for differences in borrower-related factors plus the specific lending institution used by the borrower. ${ }^{54}$ Comparisons for lending outcomes across groups are of three types: gross (or "unmodified"), modified to account for borrower-related factors (or "borrower modified"), and modified to account for borrower-related factors plus lender (or "lender modified").

As described earlier, changes in the interest rate environment over the course of 2008 may have affected whether a loan's APR exceeded the reporting threshold set by the rules governing HMDA, making comparisons of unadjusted data on reported higher-priced lending potentially misleading. To cor-

54. Excluded from the analysis are applicants residing outside the 50 states and the District of Columbia as well as applications deemed to be business related.

Borrower-related factors are controlled for as follows: Loans are placed in cells based on their size (arrayed into buckets), the borrower's income (also arrayed into buckets), the product type, MSA, number of applicants (one or two), whether the loan was originated through a preapproval program, and, for home-purchase loans, whether a piggyback junior lien was associated with it. The applicant's (and co-applicant's) gender was further used to define cells in the analyses of differences among racial and ethnic groups, and the applicant's (and co-applicant's) race was used in the analyses of gender differences.

Once loans are placed in cells, "within cell" differences in the incidence of higher-priced lending (or APR spreads or denial rates) are computed. These differences are averaged across cells to create a modified disparity controlling for borrower-related characteristics. For the second stage of the analyses, cells are further defined by the HMDA lender, and again, average within-cell disparities are computed. These disparities control for both borrower-related characteristics and lender.

For purposes of presentation, the average borrower- and lendercontrolled within-cell disparities for each comparison group are added to the average gross incidence (or APR spread or denial rate) of the base comparison group (non-Hispanic whites in the case of comparison by race and ethnicity, and males in the case of comparison by sex). An interpretation of this number is that it is the best guess as to the incidence of higher-priced lending (or APR or denial rate) that the comparison group would have if it had the same average borrower characteristics (and lender) as the base comparison group. rect for the distortions introduced by these changes, we rely on the PMMS spread, which was defined in an earlier section as the difference between the APR on a loan and the interest rate available on loans to prime borrowers with the best credit quality, assuming the loan is a 30-year fixed-rate loan. In the tables presented in this section, we report disparities in the incidence and level of pricing using the reported HMDA pricing definition of higher-priced lending, labeled "unadjusted," and the PMMSspread definition, labeled "PMMS-spread adjusted." A loan with a PMMS spread of greater than 1.75 percentage points is treated as higher priced in the adjusted analysis.

Finally, in previous years, analyses were conducted only for conventional loans, because the incidence of higher-priced lending for FHA and VA loans was so low that a meaningful statistical comparison across different groups was not possible. As discussed earlier, this was not the case in 2008 when at least the unadjusted incidence levels for nonconventional lending were at almost the same levels as conventional lending. Consequently, the analysis for 2008 (but not 2007) was conducted separately for both conventional and nonconventional lending. ${ }^{55}$

\section{Incidence of Higher-Priced Lending by Race and Ethnicity}

The frequency of reported higher-priced lending varies across racial and ethnic groups. The 2008 HMDA data, like those from earlier years, indicate that black and Hispanic white borrowers are more likely, and Asian borrowers less likely, to obtain conventional loans with prices above the HMDA price-reporting thresholds than are non-Hispanic white borrowers (tables 19.A and 19.B). These relationships hold for both home-purchase and refinance lending and persist whether the analysis focuses on unadjusted or PMMSspread-adjusted data. However, relative to 2007, incidences declined in 2008, and differences among groups appear to be narrowing. For example, the gross PMMS-spread-adjusted home-purchase incidence was 29.7 percent for black borrowers in 2007, falling to 10.5 percent in 2008. The PMMS-spreadadjusted incidence declined as well for non-Hispanic white borrowers but by a smaller amount, from 8.4 percent to 3.7 percent.

55. Although results are reported for nonconventional lending as a whole, the analysis controls for the specific type of governmentbacked loan program (FHA, VA, or Farm Service Agency/Rural Housing Service) used. 
19. Incidence of higher-priced lending, unmodified and modified for borrower- and lender-related factors, for first liens on owner-occupied, one- to four-family, site-built homes, by race, ethnicity, and sex of borrower

A. Conventional home purchase, adjusted and unadjusted for changes in interest rates, 2007-08

Percent except as noted

\begin{tabular}{|c|c|c|c|c|c|c|c|c|}
\hline \multirow[b]{2}{*}{ Race, ethnicity, and sex } & \multirow{2}{*}{$\begin{array}{l}\text { Number of } \\
\text { loans }\end{array}$} & \multirow{2}{*}{$\begin{array}{l}\text { Unmodified } \\
\text { incidence }\end{array}$} & \multicolumn{2}{|c|}{$\begin{array}{l}\text { Modified incidence, by } \\
\text { modification factor }\end{array}$} & \multirow{2}{*}{$\begin{array}{l}\text { Number of } \\
\text { loans }\end{array}$} & \multirow{2}{*}{$\begin{array}{l}\text { Unmodified } \\
\text { incidence }\end{array}$} & \multicolumn{2}{|c|}{$\begin{array}{l}\text { Modified incidence, by } \\
\text { modification factor }\end{array}$} \\
\hline & & & $\begin{array}{l}\text { Borrower- } \\
\text { related }\end{array}$ & $\begin{array}{l}\text { Borrower- } \\
\text { related } \\
\text { plus lender }\end{array}$ & & & $\begin{array}{l}\text { Borrower- } \\
\text { related }\end{array}$ & $\begin{array}{l}\text { Borrower- } \\
\text { related } \\
\text { plus lender }\end{array}$ \\
\hline & \multicolumn{8}{|c|}{2007} \\
\hline & \multicolumn{4}{|c|}{ Unadjusted spread } & \multicolumn{4}{|c|}{ Adjusted spread } \\
\hline 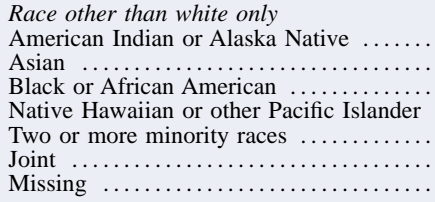 & $\begin{array}{r}13,678 \\
146,411 \\
196,967 \\
11,757 \\
1,876 \\
36,550 \\
277,348\end{array}$ & $\begin{array}{r}19.9 \\
7.7 \\
34.1 \\
17.7 \\
13.0 \\
8.9 \\
14.2\end{array}$ & $\begin{array}{r}17.9 \\
8.3 \\
29.7 \\
17.0 \\
12.8 \\
13.4 \\
18.7\end{array}$ & $\begin{array}{r}15.8 \\
9.5 \\
22.5 \\
14.2 \\
13.3 \\
12.0 \\
14.4\end{array}$ & $\begin{array}{r}13,678 \\
146,411 \\
196,967 \\
11,757 \\
1,876 \\
36,550 \\
277,348\end{array}$ & $\begin{array}{r}16.4 \\
5.9 \\
29.7 \\
14.1 \\
10.8 \\
7.3 \\
11.7\end{array}$ & $\begin{array}{r}15.0 \\
6.5 \\
25.9 \\
14.0 \\
10.4 \\
11.1 \\
15.9\end{array}$ & $\begin{array}{r}13.0 \\
7.6 \\
18.6 \\
11.4 \\
10.7 \\
9.6 \\
11.8\end{array}$ \\
\hline $\begin{array}{l}\text { White, by ethnicity } \\
\text { Hispanic white } \ldots \ldots \ldots \ldots \ldots \ldots \ldots \\
\text { Non-Hispanic white } \ldots \ldots \ldots \ldots \ldots \ldots\end{array}$ & $\begin{array}{r}261,935 \\
1,950,566\end{array}$ & $\begin{array}{l}28.7 \\
10.6\end{array}$ & $\begin{array}{l}21.3 \\
10.6\end{array}$ & $\begin{array}{l}16.5 \\
10.6\end{array}$ & $\begin{array}{r}261,935 \\
1,950,566\end{array}$ & $\begin{array}{r}23.6 \\
8.4\end{array}$ & $\begin{array}{r}17.5 \\
8.4\end{array}$ & $\begin{array}{r}13.0 \\
8.4\end{array}$ \\
\hline 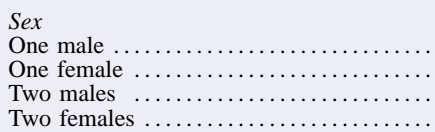 & $\begin{array}{r}906,127 \\
664,102 \\
28,649 \\
24,439\end{array}$ & $\begin{array}{l}18.6 \\
17.1 \\
14.6 \\
15.3\end{array}$ & $\begin{array}{l}18.6 \\
16.4 \\
14.6 \\
13.3\end{array}$ & $\begin{array}{l}18.6 \\
17.2 \\
14.6 \\
14.0\end{array}$ & $\begin{array}{r}906,127 \\
664,102 \\
28,649 \\
24,439\end{array}$ & $\begin{array}{l}15.2 \\
13.9 \\
11.9 \\
12.9\end{array}$ & $\begin{array}{l}15.2 \\
13.4 \\
11.9 \\
11.0\end{array}$ & $\begin{array}{l}15.2 \\
14.1 \\
11.9 \\
12.0\end{array}$ \\
\hline \multirow{2}{*}{ Two females...$\ldots \ldots \ldots \ldots \ldots \ldots \ldots$} & \multicolumn{8}{|c|}{2008} \\
\hline & \multicolumn{4}{|c|}{ Unadjusted spread } & \multicolumn{4}{|c|}{ Adjusted spread } \\
\hline 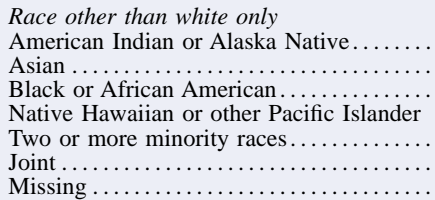 & $\begin{array}{r}5,969 \\
105,156 \\
55,987 \\
4,986 \\
1,132 \\
21,215 \\
146,339\end{array}$ & \begin{tabular}{r|r}
11.7 \\
3.3 \\
17.1 \\
7.2 \\
5.0 \\
4.9 \\
4.9
\end{tabular} & $\begin{array}{r}10.1 \\
5.9 \\
14.4 \\
8.3 \\
5.4 \\
7.3 \\
7.2\end{array}$ & $\begin{array}{r}9.4 \\
6.4 \\
14.0 \\
8.9 \\
8.6 \\
7.3 \\
7.5\end{array}$ & $\begin{array}{r}5,969 \\
105,156 \\
55,987 \\
4,986 \\
1,132 \\
21,215 \\
146,339\end{array}$ & $\begin{array}{r}7.2 \\
1.4 \\
10.5 \\
3.2 \\
2.0 \\
2.8 \\
2.4\end{array}$ & $\begin{array}{l}5.7 \\
3.2 \\
8.7 \\
4.5 \\
3.0 \\
4.2 \\
3.9\end{array}$ & $\begin{array}{l}5.0 \\
3.6 \\
8.0 \\
4.6 \\
4.1 \\
4.1 \\
4.3\end{array}$ \\
\hline $\begin{array}{l}\text { White, by ethnicity } \\
\text { Hispanic white } \ldots \ldots \ldots \ldots \ldots \ldots \ldots \ldots \ldots \\
\text { Non-Hispanic white. } \ldots \ldots \ldots \ldots \ldots \ldots \ldots\end{array}$ & $\begin{array}{r}91,804 \\
1,109,587\end{array}$ & $\begin{array}{r}15.4 \\
6.5\end{array}$ & $\begin{array}{r}11.9 \\
6.5\end{array}$ & $\begin{array}{r}11.1 \\
6.5\end{array}$ & $\begin{array}{r}91,804 \\
1,109,587\end{array}$ & $\begin{array}{l}8.5 \\
3.7\end{array}$ & $\begin{array}{l}6.8 \\
3.7\end{array}$ & $\begin{array}{l}5.8 \\
3.7\end{array}$ \\
\hline $\begin{array}{l}\text { Sex } \\
\text { One male } \ldots \ldots \ldots \ldots \ldots \ldots \ldots \ldots \ldots \\
\text { One female } \ldots \ldots \ldots \ldots \ldots \ldots \ldots \ldots \ldots \ldots \\
\text { Two males } \ldots \ldots \ldots \ldots \ldots \ldots \ldots \ldots \ldots \ldots \\
\text { Two females } \ldots \ldots \ldots \ldots \ldots \ldots \ldots \ldots\end{array}$ & $\begin{array}{r}440,197 \\
314,078 \\
17,547 \\
13,498\end{array}$ & $\begin{array}{l}8.9 \\
7.7 \\
9.6 \\
7.6\end{array}$ & $\begin{array}{l}8.9 \\
7.5 \\
9.6 \\
7.7\end{array}$ & $\begin{array}{l}8.9 \\
7.9 \\
9.6 \\
9.1\end{array}$ & $\begin{array}{r}440,197 \\
314,078 \\
17,547 \\
13,498\end{array}$ & $\begin{array}{l}5.0 \\
4.1 \\
5.6 \\
4.1\end{array}$ & $\begin{array}{l}5.0 \\
4.0 \\
5.6 \\
4.1\end{array}$ & $\begin{array}{l}5.0 \\
4.4 \\
5.6 \\
5.4\end{array}$ \\
\hline
\end{tabular}

NotE: Excludes transition-period loans (those for which the application was submitted before 2004). For definition of higher-priced lending and explanations of spread adjustment and modification factors, see text. Loans taken out

jointly by a male and female are not tabulated here because they would not be directly comparable with loans taken out by one borrower or by two borrowers of the same sex.

The gross differences in the incidence of higherpriced lending between non-Hispanic white borrowers, on the one hand, and black or Hispanic white borrowers, on the other, are relatively large; these differences are reduced some, but not completely, after controlling for borrower-related factors plus lender. For example, the gross 2008 PMMS-spreadadjusted difference for home-purchase lending between Hispanic white and non-Hispanic white borrowers falls 2.7 percentage points when other factors are accounted for $(8.5$ percent minus 3.7 percent versus 5.8 percent minus 3.7 percent). Differences in the incidences of higher-priced lending between Asian and non-Hispanic white borrowers are generally small and largely disappear after adjusting for borrowerrelated factors and lender.
As noted, changes in the interest rate environment had a particularly distortive effect on the incidence of higher-priced lending reported for FHA and VA loans. These distortions are apparent in comparisons across racial and ethnic groups (table 19.C). The unadjusted incidence of higher-priced home-purchase lending is 12.0 percent for black borrowers, almost 4 percentage points higher than the incidence of 8.1 percent for non-Hispanic whites. However, the PMMS-spreadadjusted incidences are only 2.6 percent and 1.5 percent for the two groups, respectively. Like conventional lending, controlling for borrower characteristics and lender narrows the differences among groups, but they do not entirely disappear. Overall, the results suggest that racial and ethnic disparities in the incidence of higher-priced lending may be less of an issue 
19. Incidence of higher-priced lending, unmodified and modified for borrower- and lender-related factors, for first liens on owner-occupied, one- to four-family, site-built homes, by race, ethnicity, and sex of borrower

B. Conventional refinance, adjusted and unadjusted for changes in interest rates, 2007-08

Percent except as noted

\begin{tabular}{|c|c|c|c|c|c|c|c|c|}
\hline \multirow[b]{2}{*}{ Race, ethnicity, and sex } & \multirow{2}{*}{$\begin{array}{c}\text { Number of } \\
\text { loans }\end{array}$} & \multirow{2}{*}{$\begin{array}{l}\text { Unmodified } \\
\text { incidence }\end{array}$} & \multicolumn{2}{|c|}{$\begin{array}{l}\text { Modified incidence, by } \\
\text { modification factor }\end{array}$} & \multirow{2}{*}{$\begin{array}{l}\text { Number of } \\
\text { loans }\end{array}$} & \multirow{2}{*}{$\begin{array}{l}\text { Unmodified } \\
\text { incidence }\end{array}$} & \multicolumn{2}{|c|}{$\begin{array}{l}\text { Modified incidence, by } \\
\text { modification factor }\end{array}$} \\
\hline & & & $\begin{array}{l}\text { Borrower- } \\
\text { related }\end{array}$ & $\begin{array}{l}\text { Borrower- } \\
\text { related } \\
\text { plus lender }\end{array}$ & & & $\begin{array}{l}\text { Borrower- } \\
\text { related }\end{array}$ & $\begin{array}{l}\text { Borrower- } \\
\text { related } \\
\text { plus lender }\end{array}$ \\
\hline & \multicolumn{8}{|c|}{2007} \\
\hline & \multicolumn{4}{|c|}{ Unadjusted spread } & \multicolumn{4}{|c|}{ Adjusted spread } \\
\hline 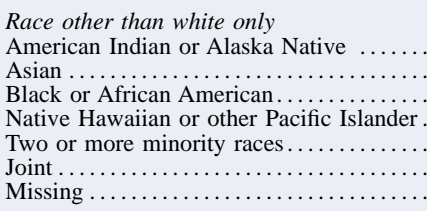 & $\begin{array}{r}19,508 \\
108,317 \\
266,661 \\
15,801 \\
2,556 \\
34,305 \\
438,423\end{array}$ & $\begin{array}{l}26.4 \\
12.5 \\
41.4 \\
23.0 \\
17.5 \\
18.6 \\
25.9\end{array}$ & $\begin{array}{l}29.2 \\
15.8 \\
38.8 \\
26.9 \\
19.3 \\
23.3 \\
31.4\end{array}$ & $\begin{array}{l}20.3 \\
17.3 \\
25.1 \\
21.9 \\
20.6 \\
19.0 \\
22.7\end{array}$ & $\begin{array}{r}19,508 \\
108,317 \\
266,661 \\
15,801 \\
2,556 \\
34,305 \\
438,423\end{array}$ & $\begin{array}{l}23.1 \\
10.1 \\
37.8 \\
19.5 \\
15.3 \\
16.4 \\
22.8\end{array}$ & $\begin{array}{l}26.1 \\
13.4 \\
35.3 \\
23.9 \\
17.5 \\
20.7 \\
28.2\end{array}$ & $\begin{array}{l}17.6 \\
14.8 \\
22.0 \\
19.0 \\
17.8 \\
16.6 \\
19.8\end{array}$ \\
\hline 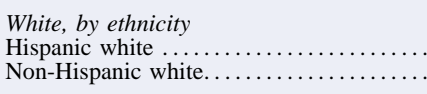 & $\begin{array}{r}302,012 \\
2,174,308\end{array}$ & $\begin{array}{l}27.0 \\
18.2\end{array}$ & $\begin{array}{l}25.3 \\
18.2\end{array}$ & $\begin{array}{l}21.4 \\
18.2\end{array}$ & $\begin{array}{r}302,012 \\
2,174,308\end{array}$ & $\begin{array}{l}22.8 \\
15.8\end{array}$ & $\begin{array}{l}21.9 \\
15.8\end{array}$ & $\begin{array}{l}18.5 \\
15.8\end{array}$ \\
\hline $\begin{array}{l}\text { Sex } \\
\text { One male } \ldots \ldots \ldots \ldots \ldots \ldots \ldots \\
\text { One female } \ldots \ldots \ldots \ldots \ldots \ldots \ldots \ldots \\
\text { Two males } \ldots \ldots \ldots \ldots \ldots \ldots \ldots \ldots \\
\text { Two females } \ldots \ldots \ldots \ldots \ldots \ldots \ldots\end{array}$ & $\begin{array}{r}927,344 \\
778,477 \\
23,147 \\
25,363 \\
\end{array}$ & $\begin{array}{l}23.8 \\
24.9 \\
19.4 \\
26.6\end{array}$ & $\begin{array}{l}23.8 \\
23.8 \\
19.4 \\
22.2 \\
\end{array}$ & $\begin{array}{l}23.8 \\
23.6 \\
19.4 \\
20.7 \\
\end{array}$ & $\begin{array}{r}927,344 \\
778,477 \\
23,147 \\
25,363 \\
\end{array}$ & $\begin{array}{l}20.6 \\
21.6 \\
17.0 \\
23.8 \\
\end{array}$ & $\begin{array}{l}20.6 \\
20.5 \\
17.0 \\
19.6 \\
\end{array}$ & $\begin{array}{l}20.6 \\
20.4 \\
17.0 \\
18.3 \\
\end{array}$ \\
\hline \multirow{2}{*}{ Two females ..................... } & \multicolumn{8}{|c|}{2008} \\
\hline & \multicolumn{4}{|c|}{ Unadjusted spread } & \multicolumn{4}{|c|}{ Adjusted spread } \\
\hline 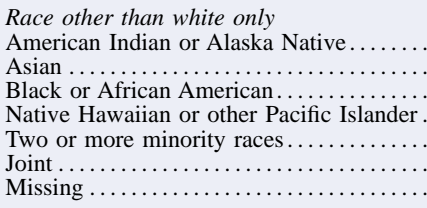 & $\begin{array}{r}9,693 \\
83,697 \\
102,119 \\
6,924 \\
2,050 \\
26,145 \\
244,501\end{array}$ & $\begin{array}{r}19.7 \\
2.9 \\
27.9 \\
10.7 \\
6.2 \\
8.1 \\
7.8\end{array}$ & $\begin{array}{r}18.8 \\
8.0 \\
24.8 \\
14.9 \\
10.4 \\
11.6 \\
10.9\end{array}$ & $\begin{array}{r}12.6 \\
9.3 \\
15.2 \\
11.0 \\
10.6 \\
10.4 \\
10.9\end{array}$ & $\begin{array}{r}9,693 \\
83,697 \\
102,119 \\
6,924 \\
2,050 \\
26,145 \\
244,501\end{array}$ & $\begin{array}{r}15.7 \\
1.7 \\
22.7 \\
7.9 \\
4.3 \\
6.1 \\
5.4\end{array}$ & $\begin{array}{r}15.4 \\
5.6 \\
20.4 \\
11.2 \\
7.4 \\
8.6 \\
7.6\end{array}$ & $\begin{array}{r}9.3 \\
6.8 \\
11.0 \\
7.7 \\
7.1 \\
7.7 \\
8.0\end{array}$ \\
\hline $\begin{array}{l}\text { White, by ethnicity } \\
\text { Hispanic white } \ldots \ldots \ldots \\
\text { Non-Hispanic white..... }\end{array}$ & $\begin{array}{r}118,457 \\
1,708,479\end{array}$ & $\begin{array}{r}14.4 \\
9.9\end{array}$ & $\begin{array}{r}13.2 \\
9.9\end{array}$ & $\begin{array}{r}11.4 \\
9.9\end{array}$ & $\begin{array}{r}118,457 \\
1,708,479\end{array}$ & $\begin{array}{r}10.2 \\
7.1\end{array}$ & $\begin{array}{l}9.5 \\
7.1\end{array}$ & $\begin{array}{l}8.1 \\
7.1\end{array}$ \\
\hline $\begin{array}{l}\text { Sex } \\
\text { One male } \ldots \ldots \ldots \ldots \ldots \ldots \ldots \ldots \ldots \\
\text { One female } \ldots \ldots \ldots \ldots \ldots \ldots \ldots \ldots \ldots \\
\text { Two males } \ldots \ldots \ldots \ldots \ldots \ldots \ldots \ldots \ldots \\
\text { Two females } \ldots \ldots \ldots \ldots \ldots \ldots \ldots \ldots \ldots\end{array}$ & $\begin{array}{r}542,449 \\
441,113 \\
16,661 \\
17,633\end{array}$ & $\begin{array}{l}11.2 \\
12.6 \\
10.3 \\
14.4\end{array}$ & $\begin{array}{l}11.2 \\
10.9 \\
10.3 \\
11.9\end{array}$ & $\begin{array}{l}11.2 \\
10.8 \\
10.3 \\
11.1\end{array}$ & $\begin{array}{r}542,449 \\
441,113 \\
16,661 \\
17,633\end{array}$ & $\begin{array}{r}8.0 \\
9.2 \\
7.3 \\
10.9\end{array}$ & $\begin{array}{l}8.0 \\
7.9 \\
7.3 \\
8.9\end{array}$ & $\begin{array}{l}8.0 \\
7.8 \\
7.3 \\
7.7\end{array}$ \\
\hline
\end{tabular}

Note: See notes to table 19.A.

for FHA or VA lending than for conventional lending, particularly when corrections are made for the distortions created by the interest rate environment. ${ }^{56}$

56. It is difficult to know how to interpret pricing disparities across groups in FHA and VA lending programs. For the most part, neither program's fees have been risk based, so it is tempting to attribute any differences in rates across groups to discrimination or other factors unrelated to credit risk. However, this may be an unwarranted simplification. Even though the FHA and VA cover most of the credit risk in a loan, they do not cover all of it. Lenders face recourse risk in the case of fraud, and elevated servicing costs in the case of borrowers who do not make their payments. Thus, FHA and VA loan rates are still likely to vary with credit risk, albeit not as much as they would if the program fees were fully risk based. Beyond credit risk, other risk factors, such as prepayment risk, may influence FHA and VA loan pricing.

\section{Rate Spreads by Race and Ethnicity}

The 2008 data indicate that among borrowers with higher-priced loans, the gross mean prices paid relative to prime (the PMMS-adjusted spread) are similar across groups for both home-purchase and refinance lending (tables 20.A, 20.B, and 20.C). This circumstance holds for both conventional and nonconventional lending. For example, for conventional homepurchase loans, the gross mean PMMS-adjusted spread was 2.76 percentage points for both Hispanic white and black borrowers, while the mean APR spread for non-Hispanic white borrowers was somewhat higher at 2.89 percentage points. Accounting for borrower-related factors or the specific lender used by 
19. Incidence of higher-priced lending, unmodified and modified for borrower- and lender-related factors, for first liens on owner-occupied, one- to four-family, site-built homes, by race, ethnicity, and sex of borrower

C. Nonconventional home purchase and refinance, 2008

Percent except as noted

\begin{tabular}{|c|c|c|c|c|c|c|c|c|}
\hline \multirow[b]{2}{*}{ Race, ethnicity, and sex } & \multirow{2}{*}{$\begin{array}{l}\text { Number of } \\
\text { loans }\end{array}$} & \multirow{2}{*}{$\begin{array}{l}\text { Unmodified } \\
\text { incidence }\end{array}$} & \multicolumn{2}{|c|}{$\begin{array}{l}\text { Modified incidence, by } \\
\text { modification factor }\end{array}$} & \multirow{2}{*}{$\begin{array}{l}\text { Number of } \\
\text { loans }\end{array}$} & \multirow{2}{*}{$\begin{array}{l}\text { Unmodified } \\
\text { incidence }\end{array}$} & \multicolumn{2}{|c|}{$\begin{array}{l}\text { Modified incidence, by } \\
\text { modification factor }\end{array}$} \\
\hline & & & $\begin{array}{l}\text { Borrower- } \\
\text { related }\end{array}$ & $\begin{array}{l}\text { Borrower- } \\
\text { related } \\
\text { plus lender }\end{array}$ & & & $\begin{array}{l}\text { Borrower- } \\
\text { related }\end{array}$ & $\begin{array}{l}\text { Borrower- } \\
\text { related } \\
\text { plus lender }\end{array}$ \\
\hline & \multicolumn{8}{|c|}{ Unadjusted spread } \\
\hline & \multicolumn{4}{|c|}{ Home purchase } & \multicolumn{4}{|c|}{ Refinance } \\
\hline 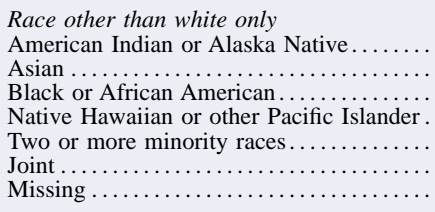 & $\begin{array}{r}7,546 \\
19,360 \\
111,375 \\
4,782 \\
802 \\
20,081 \\
87,225\end{array}$ & $\begin{array}{r}8.1 \\
7.9 \\
12.0 \\
8.8 \\
11.3 \\
7.0 \\
8.4\end{array}$ & $\begin{array}{r}9.8 \\
9.1 \\
11.9 \\
10.4 \\
12.4 \\
9.8 \\
10.7\end{array}$ & $\begin{array}{r}10.5 \\
9.2 \\
11.2 \\
9.9 \\
10.6 \\
9.7 \\
9.6\end{array}$ & $\begin{array}{r}2,270 \\
4,758 \\
73,007 \\
1,566 \\
305 \\
7,692 \\
63,069\end{array}$ & $\begin{array}{r}10.8 \\
8.2 \\
13.8 \\
12.0 \\
15.7 \\
8.8 \\
15.4\end{array}$ & $\begin{array}{r}13.3 \\
9.3 \\
16.1 \\
16.5 \\
20.5 \\
11.2 \\
16.8\end{array}$ & $\begin{array}{l}12.8 \\
10.4 \\
14.7 \\
15.1 \\
13.1 \\
11.3 \\
12.9\end{array}$ \\
\hline $\begin{array}{l}\text { White, by ethnicity } \\
\text { Hispanic white } \ldots \ldots \ldots \ldots \ldots \ldots \ldots \ldots \ldots \ldots \ldots \\
\text { Non-Hispanic white. } \ldots \ldots \ldots \ldots \ldots \ldots \ldots\end{array}$ & $\begin{array}{l}107,031 \\
719,687\end{array}$ & $\begin{array}{r}12.4 \\
8.1\end{array}$ & $\begin{array}{l}9.6 \\
8.1\end{array}$ & $\begin{array}{l}9.7 \\
8.1\end{array}$ & $\begin{array}{r}32,361 \\
368,192\end{array}$ & $\begin{array}{l}10.3 \\
11.7\end{array}$ & $\begin{array}{l}12.0 \\
11.7\end{array}$ & $\begin{array}{l}12.3 \\
11.7\end{array}$ \\
\hline 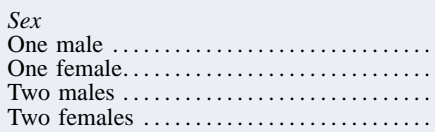 & $\begin{array}{r}328,082 \\
213,682 \\
21,843 \\
17,412\end{array}$ & $\begin{array}{r}9.6 \\
10.6 \\
12.1 \\
12.3\end{array}$ & $\begin{array}{r}9.6 \\
8.8 \\
12.1 \\
11.8\end{array}$ & $\begin{array}{r}9.6 \\
8.9 \\
12.1 \\
6.8\end{array}$ & $\begin{array}{r}148,319 \\
107,427 \\
5,988 \\
7,148\end{array}$ & $\begin{array}{l}12.5 \\
13.4 \\
12.5 \\
13.8\end{array}$ & $\begin{array}{l}12.5 \\
11.9 \\
12.5 \\
12.0\end{array}$ & $\begin{array}{l}12.5 \\
12.2 \\
12.5 \\
10.8\end{array}$ \\
\hline & \multicolumn{8}{|c|}{ Adjusted spread } \\
\hline & \multicolumn{4}{|c|}{ Home purchase } & \multicolumn{4}{|c|}{ Refinance } \\
\hline 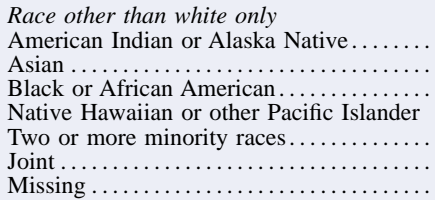 & $\begin{array}{r}7,546 \\
19,360 \\
111,375 \\
4,782 \\
802 \\
20,081 \\
87,225\end{array}$ & $\begin{array}{l}1.4 \\
1.1 \\
2.6 \\
1.5 \\
3.1 \\
1.4 \\
1.6\end{array}$ & $\begin{array}{l}1.7 \\
1.2 \\
2.4 \\
1.8 \\
4.9 \\
2.0 \\
2.5\end{array}$ & $\begin{array}{l}2.3 \\
1.5 \\
2.2 \\
1.8 \\
2.3 \\
1.9 \\
2.0\end{array}$ & $\begin{array}{r}2,270 \\
4,758 \\
73,007 \\
1,566 \\
305 \\
7,692 \\
63,069\end{array}$ & $\begin{array}{l}2.6 \\
1.4 \\
3.9 \\
3.6 \\
6.2 \\
2.4 \\
4.3\end{array}$ & $\begin{array}{l}3.2 \\
1.7 \\
4.6 \\
3.5 \\
9.7 \\
3.4 \\
4.1\end{array}$ & $\begin{array}{l}2.8 \\
2.0 \\
3.7 \\
2.7 \\
3.3 \\
3.7 \\
3.3\end{array}$ \\
\hline $\begin{array}{l}\text { White, by ethnicity } \\
\text { Hispanic white } \ldots \ldots \ldots \ldots \ldots \ldots \ldots \ldots \ldots \\
\text { Non-Hispanic white. } \ldots \ldots \ldots \ldots \ldots \ldots \ldots\end{array}$ & $\begin{array}{l}107,031 \\
719,687\end{array}$ & $\begin{array}{l}2.3 \\
1.5\end{array}$ & $\begin{array}{l}1.7 \\
1.5\end{array}$ & $\begin{array}{l}1.7 \\
1.5\end{array}$ & $\begin{array}{r}32,361 \\
368,192\end{array}$ & $\begin{array}{l}2.3 \\
2.7\end{array}$ & $\begin{array}{l}2.9 \\
2.7\end{array}$ & $\begin{array}{l}2.9 \\
2.7\end{array}$ \\
\hline 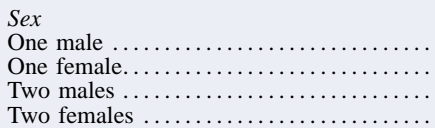 & $\begin{array}{r}328,082 \\
213,682 \\
21,843 \\
17,412\end{array}$ & $\begin{array}{l}1.8 \\
2.1 \\
2.3 \\
2.3\end{array}$ & $\begin{array}{l}1.8 \\
2.1 \\
2.3 \\
2.2\end{array}$ & $\begin{array}{l}1.8 \\
1.6 \\
2.3 \\
2.0\end{array}$ & $\begin{array}{r}148,319 \\
107,427 \\
5,988 \\
7,148\end{array}$ & $\begin{array}{l}3.1 \\
3.4 \\
2.7 \\
3.3\end{array}$ & $\begin{array}{l}3.1 \\
2.9 \\
2.7 \\
2.9\end{array}$ & $\begin{array}{l}3.1 \\
3.0 \\
2.7 \\
2.9\end{array}$ \\
\hline
\end{tabular}

NoTE: Excludes transition-period loans (those for which the application was submitted before 2004). For definition of higher-priced lending and explanation of modification factors, see text. Loans taken out jointly by a male and fe-

male are not tabulated here because they would not be directly comparable with loans taken out by one borrower or by two borrowers of the same sex. the borrowers alters the relationships, but in unpredictable ways; black and Hispanic white borrowers now have higher modified spreads relative to nonHispanic white borrowers. Patterns are similar when the analysis focuses on nonconventional loans.

\section{Pricing Differences by Sex}

The 2008 HMDA data, like those in previous years, reveal relatively little difference in pricing outcomes (PMMS-spread adjusted or spread unadjusted) when borrowers are distinguished by sex. This holds for both incidence and rate-spread comparisons (tables 19 and 20).

\section{Denial Rates by Race, Ethnicity, and Sex}

Analyses of the HMDA data from earlier years have consistently found that denial rates vary across applicants grouped by race or ethnicity. In 2008, for both home-purchase and refinance conventional lending, black and Hispanic white applicants had notably higher gross denial rates than non-Hispanic white applicants. Generally, denial rates for black applicants have been the highest, and denial rates for Hispanic white applicants were between those for black and those for non-Hispanic white applicants (tables 21.A and 21.B). The pattern for Asians was somewhat different, as the gross denial rate for this 
20. Mean APR spreads, unmodified and modified for borrower- and lender-related factors, for higher-priced loans on one- to four-family homes, by type of loan and by race, ethnicity, and sex of borrower

A. Coventional home purchase, adjusted and unadjusted for changes in interest rates, 2007-08

Percent except as noted

\begin{tabular}{|c|c|c|c|c|c|c|c|c|}
\hline \multirow[b]{2}{*}{ Race, ethnicity, and sex } & \multirow{2}{*}{$\begin{array}{c}\text { Number of } \\
\text { higher-priced } \\
\text { loans }\end{array}$} & \multirow{2}{*}{$\begin{array}{l}\text { Unmodified } \\
\text { mean spread }\end{array}$} & \multicolumn{2}{|c|}{$\begin{array}{l}\text { Modified mean spread, by } \\
\text { modification factor }\end{array}$} & \multirow{2}{*}{$\begin{array}{c}\text { Number of } \\
\text { higher-priced } \\
\text { loans }\end{array}$} & \multirow{2}{*}{$\begin{array}{l}\text { Unmodified } \\
\text { mean spread }\end{array}$} & \multicolumn{2}{|c|}{$\begin{array}{l}\text { Modified mean spread, by } \\
\text { modification factor }\end{array}$} \\
\hline & & & $\begin{array}{l}\text { Borrower- } \\
\text { related }\end{array}$ & $\begin{array}{l}\text { Borrower- } \\
\text { related plus } \\
\text { lender }\end{array}$ & & & $\begin{array}{c}\text { Borrower- } \\
\text { related }\end{array}$ & $\begin{array}{l}\text { Borrower- } \\
\text { related plus } \\
\text { lender }\end{array}$ \\
\hline & & & & & 07 & & & \\
\hline & & Unadjust & ed spread & & & Adjusted & spread & \\
\hline \multirow{2}{*}{\multicolumn{9}{|c|}{$\begin{array}{l}\text { Race other than white only } \\
\text { American Indian or Alaska Native }\end{array}$}} \\
\hline & 2,727 & 4.46 & 4.48 & 4.49 & 2,244 & 3.27 & 3.26 & 3.34 \\
\hline Asian $\ldots \ldots \ldots \ldots \ldots \ldots \ldots \ldots$ & 11,263 & 4.29 & 4.33 & 4.39 & 8,627 & 3.18 & 3.22 & 3.27 \\
\hline Black or African American .............. & 67,231 & 4.94 & 4.92 & 4.67 & 58,491 & 3.73 & 3.71 & 3.49 \\
\hline Native Hawaiian or other Pacific Islander & 2,086 & 4.52 & 4.59 & 4.53 & 1,654 & 3.42 & 3.42 & 3.40 \\
\hline Two or more minority races $\ldots \ldots \ldots \ldots$. & 243 & 4.78 & 4.83 & 4.75 & 203 & 3.62 & 3.64 & 3.67 \\
\hline Joint .................. & 3,264 & 4.65 & 4.64 & 4.52 & 2,667 & 3.52 & 3.47 & 3.38 \\
\hline Missing & 39,267 & 4.68 & 4.80 & 4.60 & 32,511 & 3.52 & 3.63 & 3.43 \\
\hline \multicolumn{9}{|l|}{ White, by ethnicity } \\
\hline Hispanic white ...... & 75,103 & 4.52 & 4.49 & 4.45 & 61,754 & 3.35 & 3.31 & 3.30 \\
\hline Non-Hispanic white . & 206,469 & 4.42 & 4.42 & 4.42 & 164,132 & 3.28 & 3.28 & 3.28 \\
\hline \multicolumn{9}{|l|}{ Sex } \\
\hline One male... & 168,684 & 4.55 & 4.55 & 4.55 & 138,085 & 3.39 & 3.39 & 3.39 \\
\hline One female & 113,427 & 4.54 & 4.54 & 4.55 & 92,374 & 3.39 & 3.40 & 3.40 \\
\hline Two males ... & 4,189 & 4.54 & 4.54 & 4.54 & 3,397 & 3.40 & 3.40 & 3.40 \\
\hline \multirow[t]{3}{*}{ Two females . } & 3,743 & 4.81 & 4.63 & 4.59 & 3,153 & 3.65 & 3.46 & 3.41 \\
\hline & \multicolumn{8}{|c|}{2008} \\
\hline & \multicolumn{4}{|c|}{ Unadjusted spread } & \multicolumn{4}{|c|}{ Adjusted spread } \\
\hline \multicolumn{9}{|l|}{ Race other than white only } \\
\hline American Indian or Alaska Native & 700 & 4.16 & 4.17 & 4.23 & 427 & 3.12 & 3.19 & 3.34 \\
\hline Asian $\ldots \ldots \ldots \ldots \ldots \ldots \ldots \ldots$ & 3,465 & 3.65 & 3.85 & 3.86 & 1,460 & 2.63 & 2.69 & 2.63 \\
\hline Black or African American............... & 9,601 & 3.88 & 4.02 & 4.10 & 5,855 & 2.76 & 2.90 & 2.99 \\
\hline Native Hawaiian or other Pacific Islander & 357 & 3.70 & 3.87 & 4.01 & 159 & 2.73 & 2.80 & 3.24 \\
\hline Two or more minority races $\ldots \ldots \ldots \ldots \ldots$ & 57 & 3.73 & 4.39 & 4.35 & 23 & 2.85 & 3.59 & 3.74 \\
\hline Joint $\ldots \ldots \ldots \ldots \ldots \ldots \ldots$ & 1,045 & 4.05 & 3.93 & 4.06 & 596 & 3.02 & 2.88 & 2.93 \\
\hline Missing ................ & 7,241 & 3.69 & 3.79 & 4.01 & 3,540 & 2.64 & 2.72 & 2.92 \\
\hline \multicolumn{9}{|l|}{ White, by ethnicity } \\
\hline Hispanic white.... & 14,130 & 3.83 & 3.96 & 4.05 & 7,776 & 2.76 & 2.84 & 2.98 \\
\hline Non-Hispanic white & 72,549 & 3.97 & 3.97 & 3.97 & 41,588 & 2.89 & 2.89 & 2.89 \\
\hline \multicolumn{9}{|l|}{ Sex } \\
\hline One male... & 39,093 & 3.87 & 3.87 & 3.87 & 21,852 & 2.79 & 2.79 & 2.79 \\
\hline One female & 24,189 & 3.80 & 3.81 & 3.83 & 12,907 & 2.72 & 2.75 & 2.76 \\
\hline Two males ... & 1,683 & 3.99 & 3.99 & 3.99 & 985 & 2.87 & 2.87 & 2.87 \\
\hline Two females . & 1,023 & 3.88 & 3.86 & 4.05 & 547 & 2.83 & 2.82 & 2.86 \\
\hline
\end{tabular}

NOTE: Unadjusted-spread annual percentage rate (APR) is the difference between the APR on the loan and the yield on a comparable-maturity Treasury security. Adjusted-spread APR is the difference between the APR on the loan and the estimated APR reported by Freddie Mac for a 30-year fixed-rate loan in its Primary Mortgage Market Survey. Excludes transition-period loans

group was higher for home-purchase loans than for non-Hispanic whites, but about the same for refinancing.

Controlling for borrower-related factors in the HMDA data reduces the differences among racial and ethnic groups. Accounting for the specific lender used by the applicant reduces differences further, although unexplained differences remain between nonHispanic whites and other racial and ethnic groups. For home-purchase conventional lending, denial rates increased only modestly for virtually all groups from 2007 through 2008 with differences between groups also changing little. Patterns for conventional refinancing are less straightforward. Denial rates for (those for which the application was submitted before 2004). For definition of higher-priced lending and explanation of modification factors, see text. Loans taken out jointly by a male and female are not tabulated here because they would not be directly comparable with loans taken out by one borrower or by two borrowers of the same sex.

virtually all minority groups (with the exception of Asians) increased by about one-tenth over the previous year while the denial rate fell for non-Hispanic white applicants. As a result, denial-rate differences between minorities and non-Hispanic whites widened.

The rank ordering of denial rates across groups is similar for nonconventional lending in 2008 (table 21.C). However, differences among groups are narrower because denial rates are uniformly lower for black and Hispanic white applicants and higher for Asians and non-Hispanic whites as compared with conventional lending. Group differences are reduced, but do not disappear, when borrower characteristics and lender are controlled for. With 
20. Mean APR spreads, unmodified and modified for borrower- and lender-related factors, for higher-priced loans on one- to four-family homes, by type of loan and by race, ethnicity, and sex of borrower

B. Conventional refinance, adjusted and unadjusted for changes in interest rates, 2007-08

Percent except as noted

\begin{tabular}{|c|c|c|c|c|c|c|c|c|}
\hline \multirow[b]{2}{*}{ Race, ethnicity, and sex } & \multirow{2}{*}{$\begin{array}{c}\text { Number of } \\
\text { higher-priced } \\
\text { loans }\end{array}$} & \multirow{2}{*}{$\begin{array}{l}\text { Unmodified } \\
\text { mean spread }\end{array}$} & \multicolumn{2}{|c|}{$\begin{array}{l}\text { Modified mean spread, by } \\
\text { modification factor }\end{array}$} & \multirow{2}{*}{$\begin{array}{c}\text { Number of } \\
\text { higher-priced } \\
\text { loans }\end{array}$} & \multirow{2}{*}{$\begin{array}{l}\text { Unmodified } \\
\text { mean spread }\end{array}$} & \multicolumn{2}{|c|}{$\begin{array}{l}\text { Modified mean spread, by } \\
\text { modification factor }\end{array}$} \\
\hline & & & $\begin{array}{l}\text { Borrower- } \\
\text { related }\end{array}$ & $\begin{array}{l}\text { Borrower- } \\
\text { related plus } \\
\text { lender }\end{array}$ & & & $\begin{array}{l}\text { Borrower- } \\
\text { related }\end{array}$ & $\begin{array}{l}\text { Borrower- } \\
\text { related plus } \\
\text { lender }\end{array}$ \\
\hline & \multicolumn{8}{|c|}{2007} \\
\hline & \multicolumn{4}{|c|}{ Unadjusted spread } & \multicolumn{4}{|c|}{ Adjusted spread } \\
\hline 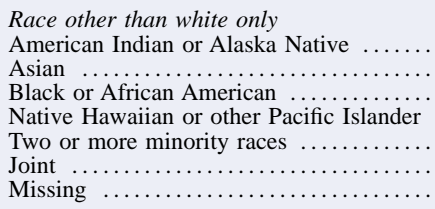 & $\begin{array}{r}5,145 \\
13,581 \\
110,464 \\
3,639 \\
447 \\
6,365 \\
113,472\end{array}$ & $\begin{array}{l}4.77 \\
4.29 \\
5.06 \\
4.63 \\
4.83 \\
4.79 \\
4.88\end{array}$ & $\begin{array}{l}4.77 \\
4.62 \\
5.04 \\
4.82 \\
4.84 \\
4.90 \\
4.97\end{array}$ & $\begin{array}{l}4.79 \\
4.69 \\
4.86 \\
4.81 \\
4.75 \\
4.82 \\
4.75\end{array}$ & $\begin{array}{r}4,515 \\
10,950 \\
100,695 \\
3,075 \\
392 \\
5,631 \\
100,081\end{array}$ & $\begin{array}{l}3.52 \\
3.11 \\
3.77 \\
3.44 \\
3.59 \\
3.53 \\
3.64\end{array}$ & $\begin{array}{l}3.50 \\
3.41 \\
3.75 \\
3.55 \\
3.58 \\
3.63 \\
3.71\end{array}$ & $\begin{array}{l}3.54 \\
3.47 \\
3.61 \\
3.56 \\
3.51 \\
3.58 \\
3.51\end{array}$ \\
\hline $\begin{array}{l}\text { White, by ethnicity } \\
\text { Hispanic white } \ldots \ldots \ldots \ldots \ldots \ldots \ldots \ldots \ldots \ldots \ldots \\
\text { Non-Hispanic white } \ldots \ldots \ldots \ldots \ldots \ldots\end{array}$ & $\begin{array}{r}81,628 \\
396,194\end{array}$ & $\begin{array}{l}4.68 \\
4.71\end{array}$ & $\begin{array}{l}4.77 \\
4.71\end{array}$ & $\begin{array}{l}4.80 \\
4.71\end{array}$ & $\begin{array}{r}68,909 \\
344,009\end{array}$ & $\begin{array}{l}3.50 \\
3.47\end{array}$ & $\begin{array}{l}3.54 \\
3.47\end{array}$ & $\begin{array}{l}3.57 \\
3.47\end{array}$ \\
\hline $\begin{array}{l}\text { Sex } \\
\text { One male } \ldots \ldots \ldots \ldots \ldots \ldots \ldots \ldots \ldots \\
\text { One female } \ldots \ldots \ldots \ldots \ldots \ldots \ldots \ldots \ldots \\
\text { Two males } \ldots \ldots \ldots \ldots \ldots \ldots \ldots \ldots \ldots \\
\text { Two females } \ldots \ldots \ldots \ldots \ldots \ldots \ldots\end{array}$ & $\begin{array}{r}221,043 \\
193,694 \\
4,502 \\
6,750 \\
\end{array}$ & $\begin{array}{l}4.77 \\
4.78 \\
4.77 \\
4.91 \\
\end{array}$ & $\begin{array}{l}4.77 \\
4.75 \\
4.77 \\
4.82\end{array}$ & $\begin{array}{l}4.77 \\
4.76 \\
4.77 \\
4.79\end{array}$ & $\begin{array}{r}191,322 \\
167,975 \\
3,937 \\
6,046 \\
\end{array}$ & $\begin{array}{l}3.55 \\
3.56 \\
3.52 \\
3.64 \\
\end{array}$ & $\begin{array}{l}3.55 \\
3.53 \\
3.52 \\
3.57\end{array}$ & $\begin{array}{l}3.55 \\
3.53 \\
3.52 \\
3.52\end{array}$ \\
\hline & & & & 20 & 08 & & & \\
\hline & & Unadjust & d spread & & & Adjustec & 1 spread & \\
\hline 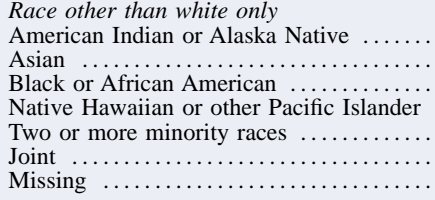 & $\begin{array}{r}1,914 \\
2,429 \\
28,476 \\
743 \\
128 \\
2,115 \\
19,179\end{array}$ & $\begin{array}{l}5.12 \\
4.08 \\
5.28 \\
4.71 \\
4.76 \\
4.72 \\
4.46\end{array}$ & $\begin{array}{l}5.00 \\
4.47 \\
5.38 \\
4.91 \\
5.12 \\
4.78 \\
4.58\end{array}$ & $\begin{array}{l}4.68 \\
4.59 \\
4.89 \\
4.70 \\
4.83 \\
4.73 \\
4.67\end{array}$ & $\begin{array}{r}1,525 \\
1,450 \\
23,191 \\
549 \\
88 \\
1,584 \\
13,155\end{array}$ & $\begin{array}{l}3.93 \\
3.08 \\
4.11 \\
3.62 \\
3.89 \\
3.58 \\
3.42\end{array}$ & $\begin{array}{l}3.79 \\
3.43 \\
4.17 \\
3.74 \\
4.28 \\
3.64 \\
3.54\end{array}$ & $\begin{array}{l}3.58 \\
3.47 \\
3.75 \\
3.66 \\
3.99 \\
3.58 \\
3.52\end{array}$ \\
\hline $\begin{array}{l}\text { White, by ethnicity } \\
\text { Hispanic white } \ldots \ldots \ldots \ldots \ldots \ldots \ldots \ldots \ldots \ldots \\
\text { Non-Hispanic white } \ldots \ldots \ldots \ldots \ldots \ldots \ldots\end{array}$ & $\begin{array}{r}17,025 \\
168,484\end{array}$ & $\begin{array}{l}4.63 \\
4.66\end{array}$ & $\begin{array}{l}4.69 \\
4.66\end{array}$ & $\begin{array}{l}4.71 \\
4.66\end{array}$ & $\begin{array}{r}12,080 \\
122,082\end{array}$ & $\begin{array}{l}3.58 \\
3.54\end{array}$ & $\begin{array}{l}3.57 \\
3.54\end{array}$ & $\begin{array}{l}3.63 \\
3.54\end{array}$ \\
\hline $\begin{array}{l}\text { Sex } \\
\text { One male } \ldots \ldots \ldots \ldots \ldots \ldots \ldots \ldots \ldots \ldots \ldots \\
\text { One female } \ldots \ldots \ldots \ldots \ldots \ldots \ldots \ldots \ldots \ldots \\
\text { Two males } \ldots \ldots \ldots \ldots \ldots \ldots \ldots \ldots \ldots \\
\text { Two females } \ldots \ldots \ldots \ldots \ldots \ldots \ldots\end{array}$ & $\begin{array}{r}60,584 \\
55,666 \\
1,710 \\
2,540\end{array}$ & $\begin{array}{l}4.63 \\
4.77 \\
4.50 \\
4.84\end{array}$ & $\begin{array}{l}4.63 \\
4.72 \\
4.50 \\
4.68\end{array}$ & $\begin{array}{l}4.63 \\
4.63 \\
4.50 \\
4.39\end{array}$ & $\begin{array}{r}43,232 \\
40,779 \\
1,221 \\
1,921\end{array}$ & $\begin{array}{l}3.56 \\
3.69 \\
3.36 \\
3.72\end{array}$ & $\begin{array}{l}3.56 \\
3.64 \\
3.36 \\
3.45\end{array}$ & $\begin{array}{l}3.56 \\
3.54 \\
3.36 \\
3.28\end{array}$ \\
\hline
\end{tabular}

Note: See notes to table 20.A.

regard to the sex of applicants, there are no notable differences for either conventional or nonconventional lending.

\section{Some Limitations of the Data in Assessing Fair Lending Compliance}

Information in the HMDA data, including borrower and loan characteristics, property location, loan origination date, and the lender identity, does not account fully for racial or ethnic differences in the incidence of higher-priced conventional lending or in denial rates for all lending types; significant differences remain unexplained. In contrast, only small differences across groups were found in the mean APR spreads paid by those receiving higher-priced loans and in the incidence of higher-priced lending for nonconventional lending. The latter finding is reassur- ing given the apparent increase in higher-priced nonconventional lending in 2008. However, removing the effects of the reporting distortions created by changes in the interest rate environment eliminates much of the difference in incidence rates among groups in nonconventional lending. Regarding the sex of borrowers, only very small differences were found in lending outcomes.

Both previous research and experience gained in the fair lending enforcement process show that unexplained differences in the incidence of higher-priced lending and in denial rates among racial or ethnic groups often stem, at least in part, from credit-related factors not available in the HMDA data, such as measures of credit history (including credit scores), loan-to-value and debt-to-income ratios, and differences in choice of loan products. Differential costs of loan origination and the competitive environment 
20. Mean APR spreads, unmodified and modified for borrower- and lender-related factors, for higher-priced loans on one- to four-family homes, by type of loan and by race, ethnicity, and sex of borrower

C. Nonconventional home purchase and refinance, 2008

Percentage points except as noted

\begin{tabular}{|c|c|c|c|c|c|c|c|c|}
\hline \multirow[b]{2}{*}{ Race, ethnicity, and sex } & \multirow{2}{*}{$\begin{array}{c}\text { Number of } \\
\text { higher-priced } \\
\text { loans }\end{array}$} & \multirow{2}{*}{$\begin{array}{l}\text { Unmodified } \\
\text { mean spread }\end{array}$} & \multicolumn{2}{|c|}{$\begin{array}{l}\text { Modified mean spread, by } \\
\text { modification factor }\end{array}$} & \multirow{2}{*}{$\begin{array}{c}\text { Number of } \\
\text { higher-priced } \\
\text { loans }\end{array}$} & \multirow{2}{*}{$\begin{array}{l}\text { Unmodified } \\
\text { mean spread }\end{array}$} & \multicolumn{2}{|c|}{$\begin{array}{l}\text { Modified mean spread, by } \\
\text { modification factor }\end{array}$} \\
\hline & & & $\begin{array}{l}\text { Borrower- } \\
\text { related }\end{array}$ & $\begin{array}{c}\text { Borrower- } \\
\text { related plus } \\
\text { lender }\end{array}$ & & & $\begin{array}{l}\text { Borrower- } \\
\text { related }\end{array}$ & $\begin{array}{c}\text { Borrower- } \\
\text { related plus } \\
\text { lender }\end{array}$ \\
\hline & \multicolumn{8}{|c|}{ Unadjusted spread } \\
\hline & \multicolumn{4}{|c|}{ Home purchase } & \multicolumn{4}{|c|}{ Refinance } \\
\hline 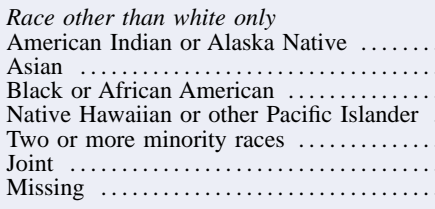 & $\begin{array}{r}610 \\
1,527 \\
13,388 \\
422 \\
91 \\
1,399 \\
7,335\end{array}$ & $\begin{array}{l}3.34 \\
3.32 \\
3.39 \\
3.36 \\
3.38 \\
3.49 \\
3.34\end{array}$ & $\begin{array}{l}3.34 \\
3.31 \\
3.40 \\
3.39 \\
3.37 \\
3.39 \\
3.39\end{array}$ & $\begin{array}{l}3.38 \\
3.37 \\
3.41 \\
3.38 \\
3.31 \\
3.39 \\
3.40\end{array}$ & $\begin{array}{r}245 \\
392 \\
10,103 \\
188 \\
48 \\
674 \\
9,712\end{array}$ & $\begin{array}{l}3.38 \\
3.31 \\
3.40 \\
3.62 \\
3.37 \\
3.38 \\
3.38\end{array}$ & $\begin{array}{l}3.43 \\
3.31 \\
3.39 \\
3.32 \\
3.51 \\
3.39 \\
3.35\end{array}$ & $\begin{array}{l}3.45 \\
3.49 \\
3.41 \\
3.35 \\
3.30 \\
3.45 \\
3.41\end{array}$ \\
\hline $\begin{array}{l}\text { White, by ethnicity } \\
\text { Hispanic white } \ldots \ldots \ldots \ldots \ldots \ldots \ldots \ldots \\
\text { Non-Hispanic white } \ldots \ldots \ldots \ldots \ldots \ldots \ldots\end{array}$ & $\begin{array}{l}13,267 \\
58,517\end{array}$ & $\begin{array}{l}3.40 \\
3.37\end{array}$ & $\begin{array}{l}3.38 \\
3.37\end{array}$ & $\begin{array}{l}3.37 \\
3.37\end{array}$ & $\begin{array}{r}3,334 \\
42,901\end{array}$ & $\begin{array}{l}3.44 \\
3.37\end{array}$ & $\begin{array}{l}3.82 \\
3.37\end{array}$ & $\begin{array}{l}3.37 \\
3.37\end{array}$ \\
\hline 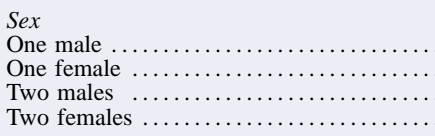 & $\begin{array}{r}31,483 \\
22,722 \\
2,650 \\
2,138 \\
\end{array}$ & $\begin{array}{l}3.37 \\
3.39 \\
3.37 \\
3.36 \\
\end{array}$ & $\begin{array}{l}3.37 \\
3.40 \\
3.37 \\
3.35 \\
\end{array}$ & $\begin{array}{l}3.37 \\
3.37 \\
3.37 \\
3.35\end{array}$ & $\begin{array}{r}18,522 \\
14,403 \\
751 \\
985\end{array}$ & $\begin{array}{l}3.38 \\
3.40 \\
3.36 \\
3.37 \\
\end{array}$ & $\begin{array}{l}3.38 \\
3.50 \\
3.36 \\
3.39\end{array}$ & $\begin{array}{l}3.38 \\
3.36 \\
3.36 \\
3.44 \\
\end{array}$ \\
\hline \multirow{2}{*}{ Two females ........ } & \multicolumn{8}{|c|}{ Adjusted spread } \\
\hline & \multicolumn{4}{|c|}{ Home purchase } & \multicolumn{4}{|c|}{ Refinance } \\
\hline 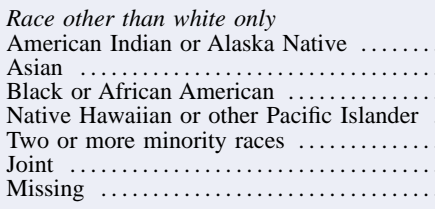 & $\begin{array}{r}109 \\
211 \\
2,906 \\
71 \\
25 \\
277 \\
1,401\end{array}$ & $\begin{array}{l}2.26 \\
2.30 \\
2.26 \\
2.41 \\
2.17 \\
2.91 \\
2.19\end{array}$ & $\begin{array}{l}2.14 \\
2.08 \\
2.38 \\
2.16 \\
1.74 \\
2.31 \\
2.37\end{array}$ & $\begin{array}{l}2.36 \\
2.27 \\
2.45 \\
2.27 \\
2.21 \\
2.29 \\
2.40\end{array}$ & $\begin{array}{r}58 \\
67 \\
2,831 \\
56 \\
19 \\
181 \\
2,713\end{array}$ & $\begin{array}{l}2.07 \\
2.11 \\
2.19 \\
2.88 \\
2.03 \\
2.20 \\
2.09\end{array}$ & $\begin{array}{l}2.30 \\
1.62 \\
2.13 \\
2.02 \\
2.34 \\
2.16 \\
2.02\end{array}$ & $\begin{array}{l}2.32 \\
2.45 \\
2.25 \\
2.35 \\
2.34 \\
2.42 \\
2.32\end{array}$ \\
\hline $\begin{array}{l}\text { White, by ethnicity } \\
\text { Hispanic white } \ldots \ldots \ldots \ldots \ldots \ldots \ldots \ldots \ldots \\
\text { Non-Hispanic white } \ldots \ldots \ldots \ldots \ldots \ldots \ldots\end{array}$ & $\begin{array}{r}2,411 \\
10,553\end{array}$ & $\begin{array}{l}2.47 \\
2.36\end{array}$ & $\begin{array}{l}2.35 \\
2.36\end{array}$ & $\begin{array}{l}2.27 \\
2.36\end{array}$ & $\begin{array}{r}731 \\
10,057\end{array}$ & $\begin{array}{l}2.61 \\
2.24\end{array}$ & $\begin{array}{l}3.42 \\
2.24\end{array}$ & $\begin{array}{l}2.23 \\
2.24\end{array}$ \\
\hline 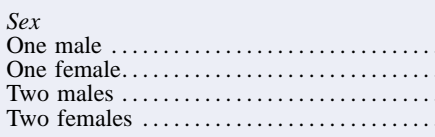 & $\begin{array}{r}5,992 \\
4,386 \\
498 \\
392\end{array}$ & $\begin{array}{l}2.30 \\
2.36 \\
2.30 \\
2.26\end{array}$ & $\begin{array}{l}2.30 \\
2.50 \\
2.30 \\
2.28\end{array}$ & $\begin{array}{l}2.30 \\
2.28 \\
2.30 \\
2.37\end{array}$ & $\begin{array}{r}4,600 \\
3,634 \\
162 \\
238\end{array}$ & $\begin{array}{l}2.20 \\
2.27 \\
2.21 \\
2.13\end{array}$ & $\begin{array}{l}2.20 \\
2.27 \\
2.21 \\
1.71\end{array}$ & $\begin{array}{l}2.20 \\
2.11 \\
2.21 \\
2.72\end{array}$ \\
\hline
\end{tabular}

NoTE: Spread annual percentage rate (APR) is the difference between the APR on the loan and the yield on a comparable-maturity Treasury security. Excludes transition-period loans (those for which the application was submitted fication factors, see text. Loans taken out jointly by a male and female are not tabulated here because they would not be directly comparable with loans taken before 2004). For definition of higher-priced lending and explanation of modi-

also may bear on the differences in pricing, as may differences across populations in credit-shopping activities.

Differences in pricing and underwriting outcomes may also be due to discriminatory treatment of minorities or other actions by lenders, including marketing practices. The HMDA data are regularly used to facilitate the fair lending examination and enforcement processes. When examiners for the federal banking agencies evaluate an institution's fair lending risk, they analyze HMDA price data in conjunction with other information and risk factors, as directed by the Interagency Fair Lending Examination Procedures. ${ }^{57}$ 
21. Denial rates on applications, unmodified and modified for borrower- and lender-related factors, for first liens on owneroccupied, one- to four-family, site-built homes, by race, ethnicity, and sex of applicant

A. Conventional home purchase, 2007-08

Percent except as noted

\begin{tabular}{|c|c|c|c|c|c|c|c|c|}
\hline \multirow[b]{2}{*}{ Race, ethnicity, and sex } & \multirow{2}{*}{$\begin{array}{l}\text { Number of } \\
\text { applications } \\
\text { acted upon } \\
\text { by lender }\end{array}$} & \multirow{2}{*}{$\begin{array}{l}\text { Unmodified } \\
\text { denial rate }\end{array}$} & \multicolumn{2}{|c|}{$\begin{array}{l}\text { Modified denial rate, } \\
\text { by modification factor }\end{array}$} & \multirow{2}{*}{$\begin{array}{c}\text { Number of } \\
\text { applications } \\
\text { acted upon } \\
\text { by lender }\end{array}$} & \multirow{2}{*}{$\begin{array}{l}\text { Unmodified } \\
\text { denial rate }\end{array}$} & \multicolumn{2}{|c|}{$\begin{array}{l}\text { Modified denial rate, } \\
\text { by modification factor }\end{array}$} \\
\hline & & & $\begin{array}{l}\text { Borrower- } \\
\text { related }\end{array}$ & $\begin{array}{l}\text { Borrower- } \\
\text { related plus } \\
\text { lender }\end{array}$ & & & $\begin{array}{l}\text { Borrower- } \\
\text { related }\end{array}$ & $\begin{array}{l}\text { Borrower- } \\
\text { related plus } \\
\text { lender }\end{array}$ \\
\hline & \multicolumn{4}{|c|}{2007} & \multicolumn{4}{|c|}{2008} \\
\hline 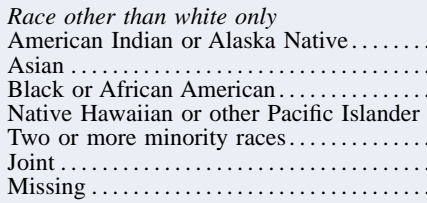 & $\begin{array}{r}22,627 \\
210,828 \\
364,887 \\
19,436 \\
2,824 \\
48,325 \\
441,246\end{array}$ & $\begin{array}{l}27.9 \\
17.4 \\
35.3 \\
27.5 \\
23.5 \\
14.5 \\
24.5\end{array}$ & $\begin{array}{l}24.8 \\
15.0 \\
30.4 \\
21.9 \\
21.7 \\
18.2 \\
23.2\end{array}$ & $\begin{array}{l}20.7 \\
15.1 \\
23.5 \\
20.2 \\
21.4 \\
15.5 \\
17.8\end{array}$ & $\begin{array}{r}9,939 \\
152,213 \\
105,001 \\
8,016 \\
1,669 \\
28,195 \\
220,395\end{array}$ & $\begin{array}{l}29.7 \\
18.7 \\
36.1 \\
26.9 \\
23.6 \\
14.8 \\
21.5\end{array}$ & $\begin{array}{l}24.6 \\
16.6 \\
29.7 \\
22.7 \\
21.9 \\
17.6 \\
19.9\end{array}$ & $\begin{array}{l}21.0 \\
16.8 \\
25.4 \\
21.0 \\
23.8 \\
15.3 \\
17.0\end{array}$ \\
\hline $\begin{array}{l}\text { White, by ethnicity } \\
\text { Hispanic white ....... } \\
\text { Non-Hispanic white.. }\end{array}$ & $\begin{array}{r}448,973 \\
2,495,779\end{array}$ & $\begin{array}{l}29.9 \\
13.2\end{array}$ & $\begin{array}{l}22.1 \\
13.2\end{array}$ & $\begin{array}{l}19.5 \\
13.2\end{array}$ & $\begin{array}{r}160,823 \\
1,425,869\end{array}$ & $\begin{array}{l}31.1 \\
13.6\end{array}$ & $\begin{array}{l}22.7 \\
13.6\end{array}$ & $\begin{array}{l}22.0 \\
13.6\end{array}$ \\
\hline $\begin{array}{l}\text { Sex } \\
\text { One male ........... } \\
\text { One female......... } \\
\text { Two males ......... } \\
\text { Two females ....... }\end{array}$ & $\begin{array}{r}1,349,211 \\
967,818 \\
41,128 \\
35,184\end{array}$ & $\begin{array}{l}22.7 \\
21.6 \\
21.0 \\
21.1\end{array}$ & $\begin{array}{l}22.7 \\
21.3 \\
21.0 \\
19.3\end{array}$ & $\begin{array}{l}22.7 \\
21.7 \\
21.0 \\
19.5\end{array}$ & $\begin{array}{r}640,030 \\
443,753 \\
25,195 \\
19,148\end{array}$ & $\begin{array}{l}21.3 \\
19.8 \\
21.1 \\
20.4\end{array}$ & $\begin{array}{l}21.3 \\
19.4 \\
21.1 \\
19.3\end{array}$ & $\begin{array}{l}21.3 \\
19.9 \\
21.1 \\
19.6\end{array}$ \\
\hline
\end{tabular}

NoTE: Includes transition-period applications (those submitted before 2004). For explanation of modification factors, see text. Applications made jointly by

comparable with applications made by one applicant or by two applicants of a male and female are not tabulated here because they would not be directly

21. Denial rates on applications, unmodified and modified for borrower- and lender-related factors, for first liens on owneroccupied, one- to four-family, site-built homes, by race, ethnicity, and sex of applicant

B. Conventional refinance, 2007-08

Percent except as noted

\begin{tabular}{|c|c|c|c|c|c|c|c|c|}
\hline \multirow[b]{2}{*}{ Race, ethnicity, and sex } & \multirow{2}{*}{$\begin{array}{c}\text { Number of } \\
\text { applications } \\
\text { acted upon } \\
\text { by lender }\end{array}$} & \multirow{2}{*}{$\begin{array}{l}\text { Unmodified } \\
\text { denial rate }\end{array}$} & \multicolumn{2}{|c|}{$\begin{array}{l}\text { Modified denial rate, } \\
\text { by modification factor }\end{array}$} & \multirow{2}{*}{$\begin{array}{l}\text { Number of } \\
\text { applications } \\
\text { acted upon } \\
\text { by lender }\end{array}$} & \multirow{2}{*}{$\begin{array}{l}\text { Unmodified } \\
\text { denial rate }\end{array}$} & \multicolumn{2}{|c|}{$\begin{array}{l}\text { Modified denial rate, } \\
\text { by modification factor }\end{array}$} \\
\hline & & & $\begin{array}{c}\text { Borrower- } \\
\text { related }\end{array}$ & $\begin{array}{l}\text { Borrower- } \\
\text { related plus } \\
\text { lender }\end{array}$ & & & $\begin{array}{l}\text { Borrower- } \\
\text { related }\end{array}$ & $\begin{array}{l}\text { Borrower- } \\
\text { related plus } \\
\text { lender }\end{array}$ \\
\hline & \multicolumn{4}{|c|}{2007} & \multicolumn{4}{|c|}{2008} \\
\hline 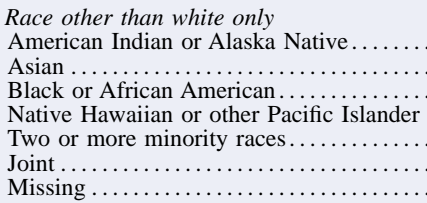 & $\begin{array}{r}59,774 \\
202,414 \\
737,786 \\
38,851 \\
6,204 \\
70,982 \\
1,147,462\end{array}$ & $\begin{array}{l}57.0 \\
32.6 \\
53.3 \\
46.3 \\
51.0 \\
41.4 \\
49.4\end{array}$ & $\begin{array}{l}53.7 \\
37.2 \\
53.5 \\
48.5 \\
51.2 \\
46.5 \\
49.8\end{array}$ & $\begin{array}{l}42.5 \\
38.0 \\
43.6 \\
43.0 \\
44.6 \\
38.5 \\
40.4\end{array}$ & $\begin{array}{r}36,265 \\
150,970 \\
343,389 \\
19,275 \\
4,682 \\
53,200 \\
532,425\end{array}$ & $\begin{array}{l}65.4 \\
31.6 \\
61.2 \\
51.8 \\
50.5 \\
41.8 \\
41.5\end{array}$ & $\begin{array}{l}56.7 \\
35.4 \\
59.9 \\
52.2 \\
49.7 \\
46.0 \\
42.5\end{array}$ & $\begin{array}{l}43.0 \\
36.1 \\
44.9 \\
43.4 \\
42.0 \\
36.8 \\
37.8\end{array}$ \\
\hline $\begin{array}{l}\text { White, by ethnicity } \\
\text { Hispanic white } \ldots \ldots . . . . \\
\text { Non-Hispanic white.... }\end{array}$ & $\begin{array}{r}695,537 \\
3,917,492\end{array}$ & $\begin{array}{l}43.4 \\
34.0\end{array}$ & $\begin{array}{l}44.0 \\
34.0\end{array}$ & $\begin{array}{l}41.6 \\
34.0\end{array}$ & $\begin{array}{r}320,845 \\
2,894,154\end{array}$ & $\begin{array}{l}50.6 \\
31.7\end{array}$ & $\begin{array}{l}45.3 \\
31.7\end{array}$ & $\begin{array}{l}41.3 \\
31.7\end{array}$ \\
\hline $\begin{array}{l}\text { Sex } \\
\text { One male .......... } \\
\text { One female........ } \\
\text { Two males ........ } \\
\text { Two females ...... }\end{array}$ & $\begin{array}{r}2,016,750 \\
1,606,563 \\
48,099 \\
55,312\end{array}$ & $\begin{array}{l}42.2 \\
40.6 \\
41.5 \\
44.7\end{array}$ & $\begin{array}{l}42.2 \\
39.5 \\
41.5 \\
42.2\end{array}$ & $\begin{array}{l}42.2 \\
40.6 \\
41.5 \\
40.9\end{array}$ & $\begin{array}{r}1,125,624 \\
889,334 \\
32,014 \\
35,706\end{array}$ & $\begin{array}{l}41.5 \\
40.7 \\
38.2 \\
41.7\end{array}$ & $\begin{array}{l}41.5 \\
39.0 \\
38.2 \\
38.5\end{array}$ & $\begin{array}{l}41.5 \\
39.6 \\
38.2 \\
36.9\end{array}$ \\
\hline
\end{tabular}

Note: See notes to table 21.A. 
21. Denial rates on applications, unmodified and modified for borrower- and lender-related factors, for first liens on owneroccupied, one- to four-family, site-built homes, by race, ethnicity, and sex of applicant

C. Nonconventional home purchase and refinance, 2008

Percent except as noted

\begin{tabular}{|c|c|c|c|c|c|c|c|c|}
\hline \multirow[b]{2}{*}{ Race, ethnicity, and sex } & \multirow{2}{*}{$\begin{array}{l}\text { Number of } \\
\text { applications } \\
\text { acted upon } \\
\text { by lender }\end{array}$} & \multirow{2}{*}{$\begin{array}{l}\text { Unmodified } \\
\text { denial rate }\end{array}$} & \multicolumn{2}{|c|}{$\begin{array}{l}\text { Modified denial rate, } \\
\text { by modification factor }\end{array}$} & \multirow{2}{*}{$\begin{array}{l}\text { Number of } \\
\text { applications } \\
\text { acted upon } \\
\text { by lender }\end{array}$} & \multirow{2}{*}{$\begin{array}{l}\text { Unmodified } \\
\text { denial rate }\end{array}$} & \multicolumn{2}{|c|}{$\begin{array}{l}\text { Modified denial rate, } \\
\text { by modification factor }\end{array}$} \\
\hline & & & $\begin{array}{l}\text { Borrower- } \\
\text { related }\end{array}$ & $\begin{array}{l}\text { Borrower- } \\
\text { related plus } \\
\text { lender }\end{array}$ & & & $\begin{array}{l}\text { Borrower- } \\
\text { related }\end{array}$ & $\begin{array}{l}\text { Borrower- } \\
\text { related plus } \\
\text { lender }\end{array}$ \\
\hline & \multicolumn{4}{|c|}{ Home purchase } & \multicolumn{4}{|c|}{ Refinance } \\
\hline 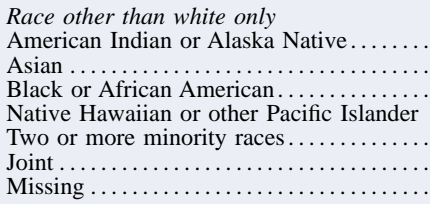 & $\begin{array}{r}10,154 \\
26,711 \\
161,187 \\
6,581 \\
1,141 \\
25,123 \\
121,400\end{array}$ & $\begin{array}{l}19.7 \\
21.3 \\
25.0 \\
21.7 \\
23.8 \\
14.7 \\
21.9\end{array}$ & $\begin{array}{l}20.6 \\
19.2 \\
24.0 \\
18.9 \\
23.3 \\
16.2 \\
20.8\end{array}$ & $\begin{array}{l}18.6 \\
18.6 \\
22.6 \\
18.3 \\
17.3 \\
16.3 \\
19.8\end{array}$ & $\begin{array}{r}5,229 \\
11,836 \\
155,665 \\
3,643 \\
873 \\
14,154 \\
165,776\end{array}$ & $\begin{array}{l}49.7 \\
51.5 \\
45.0 \\
49.7 \\
58.2 \\
38.7 \\
54.6\end{array}$ & $\begin{array}{l}49.6 \\
49.0 \\
47.2 \\
47.7 \\
59.7 \\
44.1 \\
47.7\end{array}$ & $\begin{array}{l}43.6 \\
45.1 \\
46.1 \\
47.2 \\
53.1 \\
42.2 \\
43.9\end{array}$ \\
\hline $\begin{array}{l}\text { White, by ethnicity } \\
\text { Hispanic white .......... } \\
\text { Non-Hispanic white..... }\end{array}$ & $\begin{array}{l}152,228 \\
890,659\end{array}$ & $\begin{array}{l}24.0 \\
14.1\end{array}$ & $\begin{array}{l}19.8 \\
14.1\end{array}$ & $\begin{array}{l}20.0 \\
14.1\end{array}$ & $\begin{array}{r}73,118 \\
662,593\end{array}$ & $\begin{array}{l}47.6 \\
37.5\end{array}$ & $\begin{array}{l}44.1 \\
37.5\end{array}$ & $\begin{array}{l}44.3 \\
37.5\end{array}$ \\
\hline $\begin{array}{l}\text { Sex } \\
\text { One male } \ldots \ldots \ldots \ldots \ldots \ldots \ldots \ldots \ldots \ldots \ldots \\
\text { One female } \ldots \ldots \ldots \ldots \ldots \ldots \ldots \ldots \ldots \ldots \\
\text { Two males } \ldots \ldots \ldots \ldots \ldots \ldots \ldots \ldots \ldots \\
\text { Two females } \ldots \ldots \ldots \ldots \ldots \ldots\end{array}$ & $\begin{array}{r}433,829 \\
283,404 \\
29,772 \\
23,519\end{array}$ & $\begin{array}{l}19.0 \\
19.2 \\
20.9 \\
20.5\end{array}$ & $\begin{array}{l}19.0 \\
17.7 \\
20.9 \\
18.7\end{array}$ & $\begin{array}{l}19.0 \\
17.8 \\
20.9 \\
18.5\end{array}$ & $\begin{array}{r}300,070 \\
219,503 \\
11,826 \\
13,808\end{array}$ & $\begin{array}{l}42.8 \\
44.0 \\
41.8 \\
41.2\end{array}$ & $\begin{array}{l}42.8 \\
41.2 \\
41.8 \\
40.3\end{array}$ & $\begin{array}{l}42.8 \\
41.3 \\
41.8 \\
40.3\end{array}$ \\
\hline
\end{tabular}

Note: See notes to table 21.A.

\section{APPENDIX A: REQUIREMENTS OF REGULATION C}

The Federal Reserve Board's Regulation C requires lenders to report the following information on homepurchase and home-improvement loans and on refinance loans:

\section{For each application or loan}

- application date and the date an action was taken on the application

- action taken on the application

- approved and originated

- approved but not accepted by the applicant

- denied (with the reasons for denial-voluntary for some lenders

- withdrawn by the applicant

- file closed for incompleteness

- preapproval program status (for home-purchase loans only)

- preapproval request denied by financial institution

- preapproval request approved but not accepted by individual

- loan amount

- loan type

- conventional

- insured by the Federal Housing Administration

- guaranteed by the U.S. Department of Veterans Affairs
- backed by the Farm Service Agency or Rural Housing Service

- lien status

- first lien

- junior lien

- unsecured

- loan purpose

- home purchase

- refinance

- home improvement

- type of purchaser (if the lender subsequently sold the loan during the year)

- Fannie Mae

- Ginnie Mae

- Freddie Mac

- Farmer Mac

- Private securitization

- Commercial bank, savings bank, or savings association

- Life insurance company, credit union, mortgage bank, or finance company

- Affiliate institution

- Other type of purchaser

For each applicant or co-applicant

- race

- ethnicity

- $\operatorname{sex}$

- income relied on in credit decision 
For each property

- location, by state, county, metropolitan statistical area, and census tract

- type of structure

- one- to four-family dwelling

- manufactured home

- multifamily property (dwelling with five or more units)

- occupancy status (owner occupied, non-owner occupied, or not applicable)

For loans subject to price reporting

- spread above comparable Treasury security

For loans subject to the Home Ownership and Equity Protection Act

- indicator of whether loan is subject to the Home Ownership and Equity Protection Act

\section{APPENDIX B: PRIVATE MORTGAGE} INSURANCE DATA

Historically, mortgage lenders have required a prospective borrower to make a down payment of at least 20 percent of a home's value before they will extend a loan to buy a home or refinance an existing loan. Such down payments are required because experience has shown that homeowners with little equity are substantially more likely to default on their mortgages. Private mortgage insurance (PMI) emerged as a response to creditors' concerns about the elevated credit risk of lending backed by little equity in a home as well as the difficulties that some consumers encounter in accumulating sufficient savings to meet the required down payment and closing costs.

PMI protects a lender if a borrower defaults on a loan; it reduces a lender's credit risk by insuring against losses associated with default up to a contrac- tually established percentage of the claim amount. The costs of the insurance are typically paid by the borrower through a somewhat higher interest rate on the loan.

In 1993, the Mortgage Insurance Companies of America (MICA) asked the Federal Financial Institutions Examination Council (FFIEC) to process data from PMI companies on applications for mortgage insurance and to produce disclosure statements for the public based on the data. ${ }^{58}$ The PMI data largely mirror the types of information submitted by lenders covered by the Home Mortgage Disclosure Act of 1975 (HMDA). However, because the PMI companies do not receive all the information about a prospective loan from the lenders seeking insurance coverage, some HMDA items are not included in the PMI data. In particular, loan pricing information, requests for preapproval, and an indicator of whether a loan is subject to the Home Ownership and Equity Protection Act are unavailable in the PMI data.

The eight PMI companies that issued PMI during 2008 submitted data to the FFIEC through MICA. In total, these companies acted on more than 1.55 million applications for insurance, including 1.06 million applications to insure mortgages for purchasing homes and 490,000 applications to insure mortgages for refinancing existing mortgages. PMI companies approved 87 percent of the applications they received. Approval rates for PMI companies are notably higher than they are for mortgage lenders because lenders applying for PMI are familiar with the underwriting standards used by the PMI companies and generally submit applications for insurance coverage only if the applications are likely to be approved.

58. Founded in 1973, MICA is the trade association for the PMI industry. The FFIEC prepares disclosure statements for each of the PMI companies. The statements are available at the corporate headquarters of each company and at a central depository in each metropolitan statistical area in which HMDA data are held. The PMI data are available from the FFIEC at www.ffiec.gov/reports.htm. 